Solubility and Speciation Results from Over-and Undersaturation Experiments on Neptunium, Plutonium, and Americium in Water from Yucca Mountain Region Well UE-25p \#1

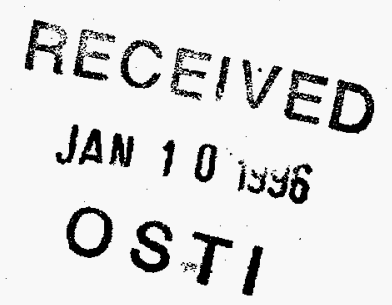


This work was supported by the Yucca Mountain Site Characterization Office as part of the Civilian Radioactive Waste Management Program. This project is managed by the U.S. Department of Energy, Yucca Mountain Site Characterization Project. In compliance with AP-5.1Q the Los Alamos Data Tracking Number for this record package segment is LA000000000101.001.

This work was performed at the Lawrence Berkeley Laboratory for the Los Alamos National Laboratory. The Lawrence Berkeley Laboratory is operated by the University of California for the US Department of Energy under Contract DE-AC-03-76SF00098.

An Affirmative Action/Equal Opportunity Employer

This report was prepared as an account of work sponsored by an agency of the United States Government. Neither The Regents of the University of California, the United States Government nor any agency thereof, nor any of their employees, makes any warranty, express or implied, or assumes any legal liability or responsibility for the accuracy, completeness, or usefulness of any information, apparatus, product, or process disclosed, or represents that its use would not infringe privately owned rights. Reference herein to any specific commercial product, process, or service by trade name, trademark, manufacturer, or otherwise, does not necessarily constitute or imply its endorsement, recommendation, or favoring by The Regents of the University of California, the United States Government, or any agency thereof. The views and opinions of authors expressed herein do not necessarily state or reflect those of The Regents of the University of California, the United States Government, or any agency thereof. The Los Alamos National Laboratory strongly supports academic freedom and a researcher's right to publish; therefore, the Laboratory as an institution does not endorse the viewpoint of a publication or guarantee its technical correctness. 


\section{DISCLAMMIER}

Portions of this document may be illegible in electronic image products. Images are produced from the best available original document. 
Solubility and Speciation Results from

Over-and Undersaturation Experiments

on Neptunium, Plutonium, and Americium

in Water from Yucca Mountain Region

Well UE-25p \#1

H. Nitsche*

K. Roberts*

K. Becraft*

T. Prussin*

D. Keeney*

S. A. Carpenter*

D.E. Hobart*

* Lawrence Berkeley Laboratory, University of California

Earth Sciences Division, I Cyclotron Road, Mail Stop 70A-1150

Berkeley, CA 94720 


\title{
SOLUBILITY AND SPECIATION RESULTS FROM OVER- AND UNDERSATURATION EXPERIMENTS ON NEPTUNIUM, PLUTONIUM, AND AMERICIUM IN WATER FROM YUCCA MOUNTAIN REGION WELL UE-25P \#1
}

\author{
by \\ H. Nitsche, K. Roberts, K. Becraft, T. Prussin, D. Keeney, \\ S.A. Carpenter, and D.E. Hobart
}

\begin{abstract}
Solubility and speciation are important in understanding aqueous radionuclide transport through the geosphere. They define the source term for transport retardation processes such as sorption and colloid formation. Solubility and speciation data are useful in verifying the validity of geochemical codes that are a part of predictive transport models. Ideally, solubility experiments should approach solution equilibrium from both oversaturation and undersaturation. Results are compared from solubility and speciation experiments from oversaturation and undersaturation of ${ }^{237} \mathrm{NpO}_{2}+,{ }^{239} \mathrm{Pu}^{4+}$, and ${ }^{241} \mathrm{Am}^{3+} / \mathrm{Nd}^{3+}$ in a modified UE-25p \#1 groundwater (from the Yucca Mountain region, Nevada, which is being investigated as a potential high-level nuclear waste disposal site) at $60^{\circ} \mathrm{C}$ and three $\mathrm{pH}$ values $(6.0,7.0,8.5)$. In the oversaturation experiments, the solubility-controlling steady-state solids were identified and the speciation and/or oxidation states present in the supernatant solutions were determined. The characterized solids were then reintroduced into fresh solutions of the modified UE-25p \#1 groundwater to approach the steady state from undersaturation. For the undersaturation experiments, the solubility-controlling steady-state solids were also identified and the speciation and/or oxidation states present in the supernatant solutions were determined. The neptunium solubility decreased with increasing $\mathrm{pH}$ in both the over- and undersaturation experiments. The steady-state concentrations from the two experiments agreed to within an order of magnitude. Plutonium concentrations from over- and undersaturation agree very well in the $\mathrm{pH} 6$ and 7 experiments. The $\mathrm{pH} 8.5$ oversaturation experiment resulted in a steady-state concentration one order of magnitude above its undersaturation counterpart. It appears that a new, more crystalline solid formed in the $\mathrm{pH} 8.5$ undersaturation cell. All five of the other cells resulted in steady-state concentrations equivalent to each other within the error of the measurement. For the americium/neodymium solutions, the $\mathrm{pH} 6$ and $\mathrm{pH} 7$ experiments resulted in equivalent steady-state concentrations from both over and undersaturation. The $\mathrm{pH} 8.5$ oversaturation experiment was 100 times more soluble than its undersaturation counterpart. This is probably due to the oversaturation cell not being at steady-state at the termination of the experiment. Otherwise, the solubility decreased with increasing $\mathrm{pH}$.
\end{abstract}




\section{PREFACE}

This report is the third in a series documenting experimental solubility and speciation studies of radionuclides in groundwaters from the Yucca Mountain region. The objectives and experimental concepts were discussed in detail in the first report of this series (Milestone 3010), entitled "Measured Solubilities and Speciations of Neptunium, Plutonium, and Americium in a Typical Groundwater from the Yucca Mountain Region."' Sections 2, 3, and 4 of this report are, except for minor changes, identical to the respective sections of the first report. They are, however, included here to make this report a stand-alone document. 


\section{TABLE OF CONTENTS}

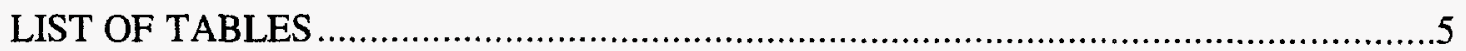

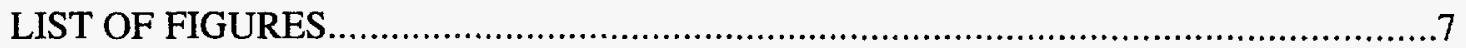

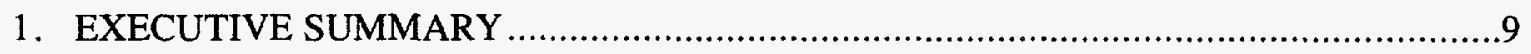

2. PURPOSE AND OBJECTIVE ........................................................................ 14

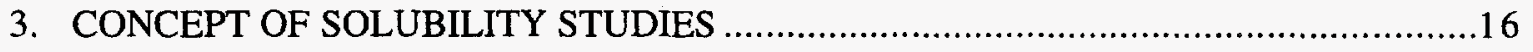

3.1. Oversaturation and Undersaturation .................................................16

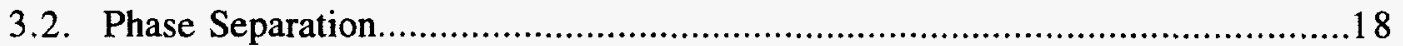

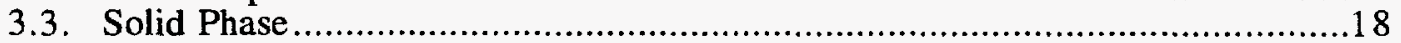

3.4. Determination of Oxidation States and Speciation...................................19

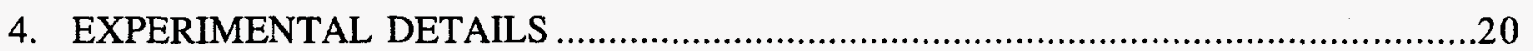

4.1. Controlled-Atmosphere Glove Box .......................................................21

4.2. Control System for $\mathrm{pH}$ and Temperature ............................................21

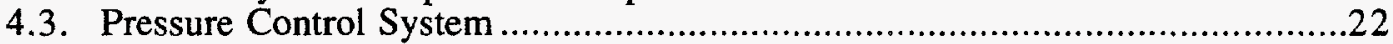

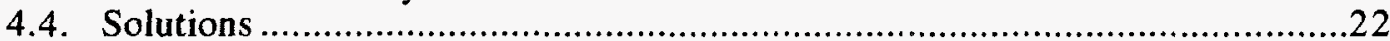

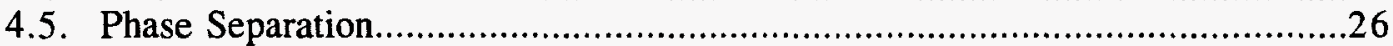

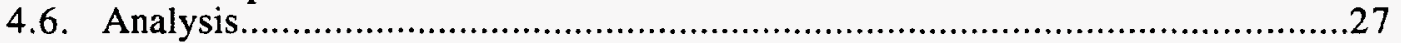

4.7. Criteria for Steady-State Concentrations......................................... 27

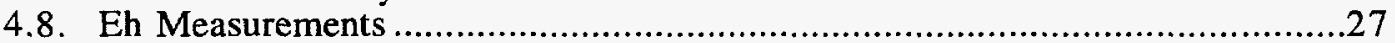

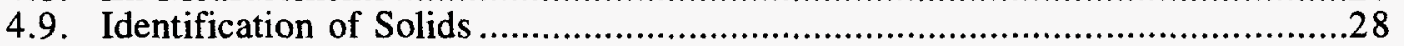

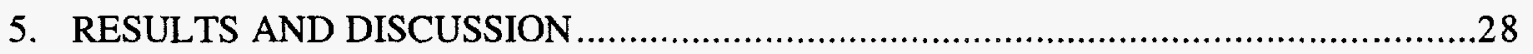

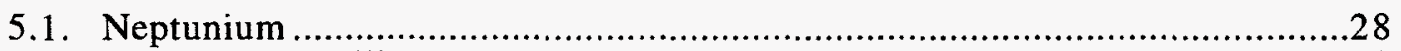

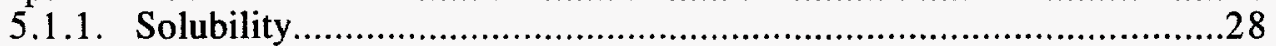

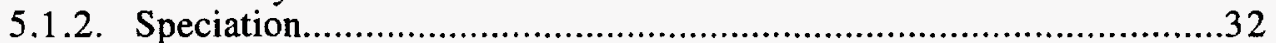

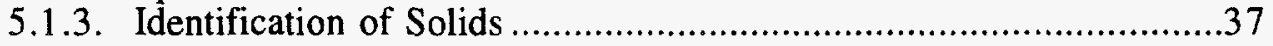

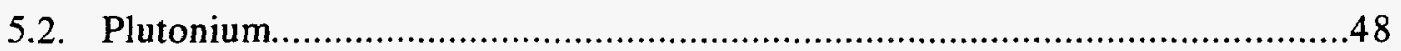

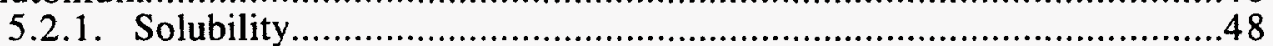

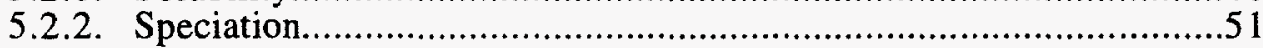

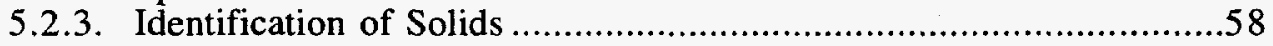

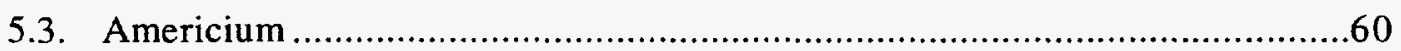

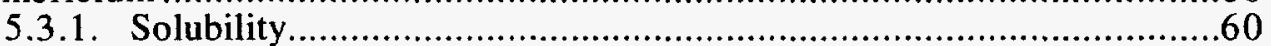

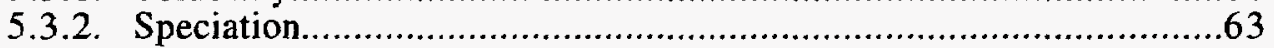

5.3.3. Identification of Solids ....................................................63

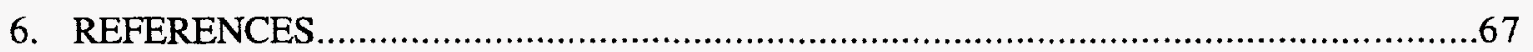

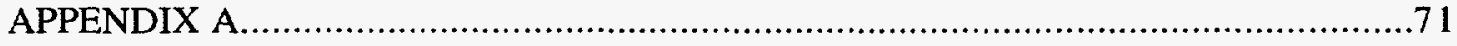

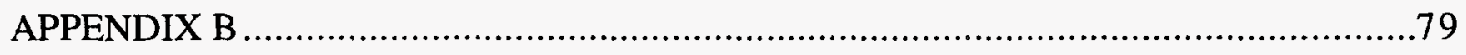

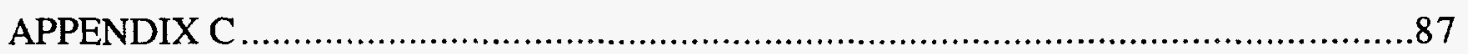




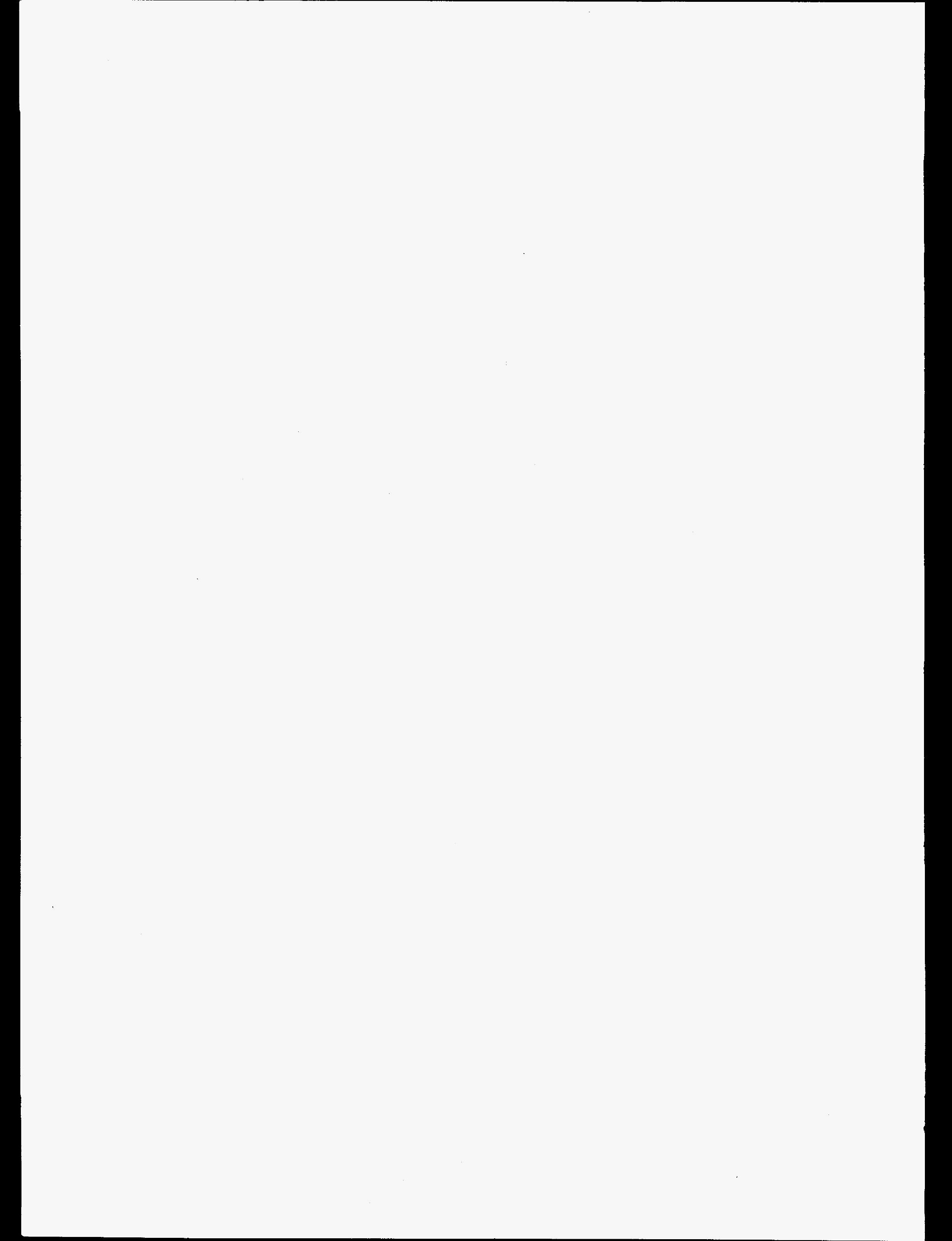




\section{LIST OF TABLES}

Table I. Summary of results for solubility experiments of neptunium in UE-25p

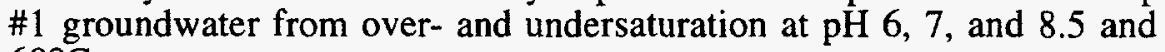
$60^{\circ} \mathrm{C}$.

Table II. Summary of results for solubility experiments of plutonium in UE-25p $\# 1$ groundwater from over- and undersaturation at $\mathrm{pH} 6,7$, and 8.5 and $60^{\circ} \mathrm{C}$.

Table III, Summary of results for solubility experiments of americium/neodymium in UE-25p \#1 groundwater from over- and undersaturation at $\mathrm{pH} 6,7$, and 8.5 and $60^{\circ} \mathrm{C}$

Table IV. UE-25p \#1 Water Composition.

Table V. Concentrations (in percent) of carbon dioxide gas in argon to maintain a total dissolved carbonate concentration of $1.531 \times 10^{-2} \mathrm{M}$ in UE-25p \#1 water at different $\mathrm{pH}$ 's together with the values for Henry's constant and the dissociation constants for carbonic acid used to determine the $\mathrm{pCO}_{2}$ values.

Table VI. Comparison of steady-state solution concentrations and Eh for neptunium over- and undersaturation experiments in UE-25p \#1 groundwater at $60^{\circ} \mathrm{C}$.......

Table VII. Comparison of extent of carbonate complexation for steady-state solutions of neptunium in UE-25p \#1 groundwater from over- and undersaturation at $60^{\circ} \mathrm{C}$.

Table VIII. X-ray powder diffraction patterns of neptunium solid phases from oversaturation in UE-25p \#1 groundwater at $60^{\circ} \mathrm{C}$ and $\mathrm{pH} 6,7$, and 8.5

Table IX. X-ray powder diffraction pattern of neptunium solid phase from undersaturation in UE-25p \#1 groundwater at $60^{\circ} \mathrm{C}$ and $\mathrm{pH} 6$ removed after day 210 , compared with oversaturation solids from $\mathrm{pH} 6$ and 7 ....

Table X.

$\mathrm{X}$-ray powder diffraction patterns of neptunium solid phases from undersaturation in UE-25p \#1 groundwater at $60^{\circ} \mathrm{C}$ and $\mathrm{pH} 6,7$, and 8.5 (solids removed at the conclusion of all experiments).

Table XI. X-ray powder diffraction pattern of neptunium solid phase from undersaturation in UE-25p \#1 groundwater at $60^{\circ} \mathrm{C}$ and $\mathrm{pH} 6$ removed after day 210 , compared with the pattern of $\mathrm{NaNpO}_{2} \mathrm{CO}_{3} \cdot 3.5 \mathrm{H}_{2} \mathrm{O}$.

Table XII. X-ray powder diffraction pattern of neptunium solid phase from undersaturation in UE-25p \#1 groundwater at $60^{\circ} \mathrm{C}$ and $\mathrm{pH} 6$ removed after day 210 , compared with the pattern of $\mathrm{NaNpO}_{2} \mathrm{CO}_{3}$.

Table XIII. X-ray powder diffraction pattern of neptunium solid phase from undersaturation in UE-25p \#1 groundwater at $60^{\circ} \mathrm{C}$ and $\mathrm{pH} 6$ removed at day 410 , compared with the patterns of $\mathrm{NaNpO}_{2} \mathrm{CO}_{3}$ and $\mathrm{KNpO}_{2} \mathrm{CO}_{3}$

Table XIV. X-ray powder diffraction pattern of neptunium solid phase from undersaturation in UE-25p \#1 groundwater at $60^{\circ} \mathrm{C}$ and $\mathrm{pH} 7$ compared with the pattern of $\mathrm{Na}_{0.6} \mathrm{NpO}_{2}\left(\mathrm{CO}_{3}\right)_{0.8} \cdot 2.5 \mathrm{H}_{2} \mathrm{O}$..... 
Table XV. X-ray powder diffraction pattern of neptunium solid phase from undersaturation in UE-25p \#1 groundwater at $60^{\circ} \mathrm{C}$ and $\mathrm{pH} 8.5$ compared with the pattern of $\mathrm{Na}_{3} \mathrm{NpO}_{2}\left(\mathrm{CO}_{3}\right)_{2} \bullet \mathrm{H}_{2} \mathrm{O}$.

Table XVI. Comparison of steady-state solution concentrations and Eh for plutonium from over- and undersaturation in UE-25p \#1 water at $60^{\circ} \mathrm{C}$

Table XVII. Methods used for determining Plutonium oxidation states in solution.

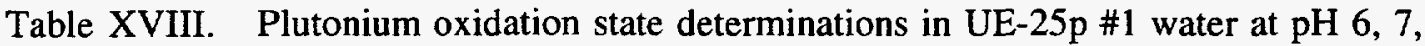
and 8.5 and $60^{\circ} \mathrm{C}$

Table XIX. X-ray powder diffraction patterns of plutonium solid phases from oversaturation in UE-25p \#1 groundwater at $60^{\circ} \mathrm{C}$ and $\mathrm{pH} 6,7$, and 8.5

Table XX. Comparison of steady-state solution concentrations and Eh for americium/ neodymium from over- and undersaturation in UE-25p \#1 water at $60^{\circ} \mathrm{C}$

Table XXI. X-ray powder diffraction patterns of Nd/241 Am solid phases in UE-25p \#1 groundwater from over- and undersaturation at $60^{\circ} \mathrm{C}$ and $\mathrm{pH} 6,7$, and 8.5 .

Table XXII. X-ray powder diffraction patterns of $\mathrm{Nd} /{ }^{241} \mathrm{Am}$ solid phases in UE-25p \#1 groundwater from undersaturation at $60^{\circ} \mathrm{C}$ and $\mathrm{pH} 6,7$, and 8.5 compared with reference patterns of: 1.) $\mathrm{Nd}_{2}\left(\mathrm{CO}_{3}\right)_{3} \cdot 2 \mathrm{H}_{2} \mathrm{O} ; 2$.) orthorhombic $\mathrm{NdOHCO}_{3}$ .66 


\section{LIST OF FIGURES}

Figure 1. Results of the neptunium solubility experiments from over- and undersaturation in UE-25p \#1 groundwater as a function of $\mathrm{pH}$.

Figure 2. Solution concentrations of ${ }^{237} \mathrm{~Np}$ in contact with precipitate obtained from supersaturation of UE-25p $\# 1$ groundwater at $60^{\circ} \mathrm{C}$ as a function of time.

Figure 3. Near-IR absorption spectra of $\mathrm{Np}$ supernatant solutions at steady-state formed in UE-25p \#1 groundwater from oversaturation at $60^{\circ} \mathrm{C}$ in $\mathrm{pH} 6$

Figure 4. Near-IR absorption spectra of Np supernatant solutions at steady-state formed in UE-25p \#1 groundwater from oversaturation at $60^{\circ} \mathrm{C}$ in $\mathrm{pH} 7$

Figure 5. Near-IR absorption spectra of Np supernatant solutions at steady-state formed in UE-25p \#1 groundwater from oversaturation at $60^{\circ} \mathrm{C}$ in $\mathrm{pH}$ 8.5 .

Figure 6. Near-IR absorption spectra of Np supernatant solutions at steady-state formed in UE-25p \#1 groundwater from undersaturation at $60^{\circ} \mathrm{C}$ in $\mathrm{pH} 6$

Figure 7. Near-IR absorption spectra of Np supernatant solutions at steady-state

formed in UE-25p \#1 groundwater from undersaturation at $60^{\circ} \mathrm{C}$ in $\mathrm{pH} 7$

Figure 8. Near-IR absorption spectra of Np supernatant solutions at steady-state formed in UE-25p \#1 groundwater from undersaturation at $60^{\circ} \mathrm{C}$ in $\mathrm{pH}$ 8.5 .

Figure 9. Deconvolution of the spectrum from the neptunium undersaturation experiment at $\mathrm{pH} 7$ and $60^{\circ} \mathrm{C}$ showing the two deconvoluted peaks at 980.6 and $991 \mathrm{~nm}$.

Figure 10. Results of the plutonium solubility experiments from over- and undersaturation in UE-25p \#1 groundwater at $60^{\circ} \mathrm{C}$ as a function of $\mathrm{pH}$.

Figure 11 Solution concentrations of ${ }^{239} \mathrm{Pu}$ in contact with precipitate obtained from supersaturation of UE-25p \#1 groundwater at $60^{\circ} \mathrm{C}$ as a function of time.

Figure 12. Plutonium oxidation state distributions of the supernatant at steady-state for $\mathrm{Pu}^{4+}$ solubility experiments from over- and undersaturation in UE$25 \mathrm{p} \# 1$ groundwater at $\mathrm{pH} 6$ and $60^{\circ} \mathrm{C}$.

Figure 13. Plutonium oxidation state distributions of the supernatant at steady-state for $\mathrm{Pu}^{4+}$ solubility experiments from over- and undersaturation in UE$25 \mathrm{p} \# 1$ groundwater at $\mathrm{pH} 7$ and $60^{\circ} \mathrm{C}$

Figure 14. Plutonium oxidation state distributions of the supernatant at steady-state for $\mathrm{Pu}^{4+}$ solubility experiments from over- and undersaturation in UE$25 \mathrm{p} \# 1$ groundwater at $\mathrm{pH} 8.5$ and $60^{\circ} \mathrm{C}$. 
Figure 15. Results for ${ }^{241} \mathrm{Am}^{3+} / \mathrm{Nd}^{3+}$ solubility experiments from over- and undersaturation in UE-25p \#1 groundwater at $60^{\circ} \mathrm{C}$ as a function of $\mathrm{pH}$.................61

Figure 16. Solution concentrations of ${ }^{241} \mathrm{Am} / \mathrm{Nd}$ in contact with precipitate obtained from supersaturation of UE-25p \#1 groundwater at $60^{\circ} \mathrm{C}$ as a function of time. 62 


\section{EXECUTIVE SUMMARY}

We studied the solubilities of neptunium, plutonium, and americium in a modified UE-25p \#1 groundwater from the Yucca Mountain region (Nevada) from over- and undersaturation at $60^{\circ} \mathrm{C}$ and pH's 6, 7, and 8.5. Tables I, II, and III summarize the results for neptunium, plutonium, and americium, respectively. The nuclides were added to UE-25p \#1 groundwater from oversaturation at the beginning of each experiment as ${ }^{237} \mathrm{NpO}_{2}{ }^{+},{ }^{239} \mathrm{Pu}^{4+}$, and $\mathrm{Nd}^{3+}$ with tracer ${ }^{241} \mathrm{Am}^{3+}$ added to facilitate nuclear counting. Because we maintained constant $\mathrm{pH}$ values of 6,7 , and 8.5 during the course of the experiments, the final solutions were closer to $0.1 \mathrm{M}$ in total ionic strength with the primary constituents being sodium and perchlorate. The solids formed in the oversaturation experiment were then reintroduced into fresh UE-25p \#1 groundwater to conduct the undersaturation experiments. At the conclusion of the undersaturation experiments the resulting solids were removed and characterized.

The neptunium solubility decreased with increasing $\mathrm{pH}$ in both the over- and undersaturation experiments. The steady-state concentrations from over- and undersaturation agreed within one order of magnitude. The soluble neptunium did not change oxidation state at steady-state. The pentavalent neptunium was increasingly complexed by carbonate with increasing $\mathrm{pH}$. The steadystate solids were crystalline sodium neptunium carbonate hydrates with varying stoichiometry.

Plutonium concentrations showed no trend with $\mathrm{pH}$. The oversaturation and undersaturation steady-state concentrations agreed within the error of the measurement for $\mathrm{pH} 6$ and $\mathrm{pH} 7$. The pH 8.5 oversaturation experiment resulted in a steady-state concentration one order of magnitude above the undersaturation experiment. This was due to formation of a more crystalline solid in the $\mathrm{pH} 8.5$ undersaturation cell. The dominant oxidation state was $\mathrm{Pu}(\mathrm{VI})$ in all experiments, with a large contribution from $\mathrm{Pu}(\mathrm{V})$ in all of the undersaturation cells. The species responsible for this oxidation are unknown. The solubility-controlling solids from oversaturation at $\mathrm{pH} 6$ and 7 were amorphous and contained $\mathrm{Pu}(\mathrm{IV})$ polymer. The solid produced in the $\mathrm{pH} 8.5$ oversaturation cell is crystalline but unidentified. All of the undersaturation solids appear to be similar and yielded similar steady-state concentrations. They are crystalline but unidentified.

For the americium/neodymium solutions, the solubility decreased with increasing $\mathrm{pH}$ in all of the undersaturation experiments. It appears that the $\mathrm{pH} 8.5$ oversaturation experiment did not reach steady-state until day 125 of the undersaturation experiment. The oxidation state in the supernatant of the americium/neodymium solutions remained in the trivalent state. The americium/neodymium solubility experiments in UE-25p \#1 groundwater produced mixtures of orthorhombic $\mathrm{NdOHCO}_{3}$ and $\mathrm{Nd}_{2}\left(\mathrm{CO}_{3}\right)_{3} \cdot 2 \mathrm{H}_{2} \mathrm{O}$. 
Table I. Summary of results for solubility experiments of neptunium in UE-25p \#1 groundwater from over- and undersaturation at $\mathrm{pH} 6,7$, and 8.5 and $60^{\circ} \mathrm{C}$.

\begin{tabular}{|c|c|c|c|c|}
\cline { 2 - 5 } \multicolumn{1}{c|}{} & \multicolumn{2}{|c|}{$\begin{array}{c}\text { Steady-State } \\
\text { Concentration (M) }\end{array}$} & \multicolumn{2}{c|}{$\begin{array}{c}\text { Oxidation State in } \\
\text { Supernatant Solution (\%) }\end{array}$} \\
\cline { 2 - 5 } & Oversaturation & Undersaturation & Oversaturation & Undersaturation \\
\hline $\mathrm{pH} 6$ & $(2.5 \pm 0.2) \times 10^{-3}$ & $(3.4 \pm 0.1) \times 10^{-3}$ & $\mathrm{~V}: 100 \%$ & $\mathrm{~V}: 100 \%$ \\
\hline $\mathrm{pH} 7$ & $(3.4 \pm 1.0) \times 10^{-5}$ & $(1.0 \pm 0.1) \times 10^{-4}$ & uncomplexed & $24 \%$ carbonate complexed \\
\hline $\mathrm{pH} 8.5$ & $(2.7 \pm 0.1) \times 10^{-5}$ & $(3.8 \pm 1.6) \times 10^{-5}$ & $10 \%$ carbonate complexed & $34 \%$ carbonate complexed \\
\hline & & & $\mathrm{V}: 100 \%$ & $\mathrm{~V}: 100 \%$ \\
\hline
\end{tabular}

\begin{tabular}{|c|c|c|c|c|}
\cline { 2 - 5 } \multicolumn{1}{c|}{} & \multicolumn{2}{c|}{ Eh (mV) vs. NHE } & \multicolumn{2}{c|}{ Solid Phase } \\
\cline { 2 - 5 } & Oversaturation & Undersaturation & Oversaturation & Undersaturation \\
\hline pH 6 & $(414 \pm 15)$ & $(406 \pm 15)$ & $\begin{array}{c}\text { Sodium Neptunyl(V) Carbonate } \\
\text { Hydrates }\end{array}$ & $\begin{array}{c}\text { Sodium Neptunyl(V) Carbonate } \\
\text { Hydrates }\end{array}$ \\
\hline pH 7 & $(367 \pm 15)$ & $(366 \pm 15)$ & $\begin{array}{c}\text { Sodium Neptunyl(V) Carbonate } \\
\text { Hydrates }\end{array}$ & $\begin{array}{c}\text { Sodium Neptunyl(V) Carbonate } \\
\text { Hydrates }\end{array}$ \\
\hline pH 8.5 & $(212 \pm 15)$ & $(239 \pm 15)$ & Sodium Neptunyl(V) Carbonate \\
Hydrates & $\begin{array}{c}\text { Sodium Neptunyl(V) Carbonate } \\
\text { Hydrates }\end{array}$ \\
\hline
\end{tabular}


Table II. Summary of results for solubility experiments of plutonium in UE-25p \#1 groundwater from over- and undersaturation at $\mathrm{pH} 6,7$, and 8.5 and $60^{\circ} \mathrm{C}$.

\begin{tabular}{|c|c|c|c|c|c|c|}
\hline & \multicolumn{2}{|c|}{$\begin{array}{c}\text { Steady-State } \\
\text { Concentration (M) }\end{array}$} & \multicolumn{4}{|c|}{$\begin{array}{c}\text { Oxidation State in } \\
\text { Supernatant Solution (\%) }\end{array}$} \\
\hline & Oversaturation & Undersaturation & \multicolumn{2}{|c|}{ Oversaturation } & \multicolumn{2}{|c|}{ Undersaturation } \\
\hline $\mathrm{pH} 6$ & $(8.8 \pm 1.4) \times 10^{-8}$ & $(9.5 \pm 3.6) \times 10^{-8}$ & $\begin{array}{l}\text { III + Poly. : } \\
\text { IV : } \\
\text { V : } \\
\text { VI : }\end{array}$ & $\begin{array}{l}(1 \pm 1) \\
(1 \pm 1) \\
(4 \pm 1) \\
(94 \pm 11)\end{array}$ & $\begin{array}{l}\text { III + Poly. : } \\
\text { IV : } \\
\text { V : } \\
\text { VI : }\end{array}$ & $\begin{array}{l}(1 \pm 1) \\
(2 \pm 1) \\
(39 \pm 4) \\
(57 \pm 6)\end{array}$ \\
\hline $\mathrm{pH} 7$ & $(9.1 \pm 1.2) \times 10^{-8}$ & $(6.8 \pm 3.1) \times 10^{-8}$ & $\begin{array}{l}\text { III + Poly. : } \\
\text { IV : } \\
\text { V : } \\
\text { VI : }\end{array}$ & $\begin{array}{l}(2 \pm 1) \\
(1 \pm 1) \\
(5 \pm 1) \\
(93 \pm 11)\end{array}$ & $\begin{array}{l}\text { III + Poly. : } \\
\text { IV : } \\
\text { V : } \\
\text { VI : }\end{array}$ & $\begin{array}{l}(1 \pm 1) \\
(1 \pm 1) \\
(9 \pm 2) \\
(89 \pm 10)\end{array}$ \\
\hline pH 8.5 & $(1.3 \pm 0.8) \times 10^{-6}$ & $(9.2 \pm 4.0) \times 10^{-8}$ & $\begin{array}{l}\text { III + Poly.: } \\
\text { IV : } \\
\text { V : } \\
\text { VI : }\end{array}$ & $\begin{array}{l}(5 \pm 2) \\
(10 \pm 1) \\
(0 \pm 0) \\
(86 \pm 12)\end{array}$ & $\begin{array}{l}\text { III + Poly. : } \\
\text { IV : } \\
\text { V : } \\
\text { VI : }\end{array}$ & $\begin{array}{l}(0 \pm 0) \\
(10 \pm 2) \\
(36 \pm 4) \\
(54 \pm 7)\end{array}$ \\
\hline
\end{tabular}

\begin{tabular}{|c|c|c|c|c|}
\cline { 2 - 5 } \multicolumn{1}{c|}{} & \multicolumn{2}{c|}{ Eh (mV) vs. NHE } & \multicolumn{2}{c|}{ Solid Phase } \\
\cline { 2 - 5 } & Oversaturation & Undersaturation & Oversaturation & Undersaturation \\
\hline $\mathrm{pH} 6$ & $(326 \pm 15)$ & $(312 \pm 15)$ & $\begin{array}{c}\text { Amorphous } \\
\text { Pu(IV) polymer }\end{array}$ & $\begin{array}{c}\text { Crystalline } \\
\text { Unidentified }\end{array}$ \\
\hline $\mathrm{pH} 7$ & $(334 \pm 15)$ & $(313 \pm 15)$ & $\begin{array}{c}\text { Amorphous } \\
\text { Pu(IV) polymer }\end{array}$ & $\begin{array}{c}\text { Crystalline } \\
\text { Unidentified }\end{array}$ \\
\hline $\mathrm{pH} 8.5$ & $(231 \pm 15)$ & $(218 \pm 15)$ & $\begin{array}{c}\text { Crystalline } \\
\text { Unidentified }\end{array}$ & Crystalline \\
Unidentified
\end{tabular}


Table III. Summary of results for solubility experiments of americium/neodymium in UE-

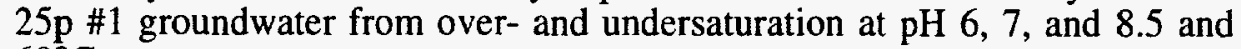
$60^{\circ} \mathrm{C}$.

\begin{tabular}{|c|c|c|c|c|}
\cline { 2 - 5 } \multicolumn{1}{c|}{} & \multicolumn{2}{|c|}{$\begin{array}{c}\text { Steady-State } \\
\text { Concentration (M) }\end{array}$} & \multicolumn{2}{c|}{$\begin{array}{c}\text { Oxidation State in } \\
\text { Supernatant Solution (\%) }\end{array}$} \\
\cline { 2 - 5 } & Oversaturation & Undersaturation & Oversaturation & Undersaturation \\
\hline $\mathrm{pH} 6$ & $(2.7 \pm 0.4) \times 10^{-9}$ & $(7.0 \pm 7.3) \times 10^{-10}$ & III $: 100 \%$ & III $: 100 \%$ \\
\hline $\mathrm{pH} 7$ & $(7.1 \pm 0.5) \times 10^{-10}$ & $(4.6 \pm 2.0) \times 10^{-10}$ & Not Available. & III : $100 \%$ \\
\hline $\mathrm{pH} 8.5$ & $(7.8 \pm 4.3) \times 10^{-9}$ & $(8.4 \pm 1.8) \times 10^{-11}$ & III $: 100 \%$ & III : $100 \%$ \\
\hline
\end{tabular}

\begin{tabular}{|c|c|c|c|c|}
\hline & \multicolumn{2}{|c|}{ Eh (mV) vs. NHE } & \multicolumn{2}{|c|}{ Solid Phase } \\
\hline & Oversaturation & Undersaturation & Oversaturation & Undersaturation \\
\hline pH 6 & $(370 \pm 15)$ & $(394 \pm 15)$ & $\begin{array}{l}(\mathrm{Am})_{2}\left(\mathrm{CO}_{3}\right)_{3} \cdot 2 \mathrm{H}_{2} \mathrm{O} \\
\text { and } \\
\text { orthorhombic } \mathrm{AmOHCO}_{3}\end{array}$ & $\begin{array}{l}(\mathrm{Am})_{2}\left(\mathrm{CO}_{3}\right)_{3} \cdot 2 \mathrm{H}_{2} \mathrm{O} \\
\text { and } \\
\text { orthorhombic } \mathrm{AmOHCO}_{3}\end{array}$ \\
\hline $\mathrm{pH} 7$ & Not Available. & $(430 \pm 15)$ & $\begin{array}{c}(\mathrm{Am})_{2}\left(\mathrm{CO}_{3}\right)_{3} \cdot 2 \mathrm{H}_{2} \mathrm{O} \\
\text { and } \\
\text { orthorhombic } \mathrm{AmOHCO}_{3} \mathrm{OHCO}\end{array}$ & $\begin{array}{l}(\mathrm{Am})_{2}\left(\mathrm{CO}_{3}\right)_{3} \cdot 2 \mathrm{H}_{2} \mathrm{O} \\
\text { and } \\
\text { orthorhombic } \mathrm{AmOHCO}_{3}\end{array}$ \\
\hline $\mathrm{pH} 8.5$ & $(220 \pm 15)$ & $(215 \pm 15)$ & $\begin{array}{l}(\mathrm{Am})_{2}\left(\mathrm{CO}_{3}\right)_{3} \cdot 2 \mathrm{H}_{2} \mathrm{O} \\
\text { and } \\
\text { orthorhombic } \mathrm{AmOHCO}\end{array}$ & $\begin{array}{l}(\mathrm{Am})_{2}\left(\mathrm{CO}_{3}\right)_{3} \cdot 2 \mathrm{H}_{2} \mathrm{O} \\
\text { and } \\
\text { orthorhombic } \mathrm{AmOHCO}_{3}\end{array}$ \\
\hline
\end{tabular}




\section{PURPOSE AND OBJECTIVE}

Yucca Mountain, Nevada, was identified for site characterization as the location for a potential repository of high-level nuclear waste. As a worst case scenario, intrusion of water into the potential repository must be considered for risk assessment. Water moving through the emplacement area towards the accessible environment can transport radionuclides in two ways: either as dissolved species in the water or as particulate material by the water. The Yucca Mountain Site Characterization Plan (SCP) requires "Studies to Provide the Information Required on Radionuclide Retardation by Precipitation Processes along Flow Paths to the Accessible Environment" before licensing and construction of the potential repository. ${ }^{2}$ The purpose of this study is to supply data for calculating radionuclide transport along potential transport pathways from the potential repository to the accessible environment. Data derived from solubility studies are important for validating geochemical codes that are part of predictive radionuclide transport models. Such codes should be capable of predicting the results of solubility experiments, where the measured solubility is the sum of the equivalent concentrations of all of the species in equilibrium with a specified solid. Furthermore, agreement between geochemical calculations and experimental results can validate the thermodynamic data base used with the modeling calculation.

To predict behavior at higher temperatures, data bases used for modeling calculations must contain data on thermodynamic functions at elevated temperatures. To date, many of these data are unavailable and are therefore estimated by extrapolation from lower temperature data. Agreement between modeling calculations and experimental results would also validate such estimates, whereas significant discrepancies would identify the need for data base improvement. Improvements can be made by filling the gaps with basic experimental data.

In addition, experimental solubility data also provide the source terms or the starting concentrations for experimental sorption studies. To be valid, sorption studies should be conducted at or below the solubility limit because only soluble species can be transported and participate in the sorption process.

In selecting these experiments, we have considered the generic U.S. Nuclear Regulatory Commission (NRC) technical position entitled "Determination of Radionuclide Solubility in Groundwater for Assessment of High-Level Waste Isolation."3 This technical position served as guidance for our experiments to determine radionuclide solubility. It requires that if radionuclide solubility is used as a factor in limiting radionuclide release, experiments must be designed to determine solubility under site-specific conditions. 
Radionuclide concentrations in water passing through the emplacement area can be limited by two mechanisms: low dissolution rates of the solid waste form or solubilities of individual radionuclides. If solid waste dissolution rates are low enough, it may not be necessary to depend on solubilities to limit radionuclide concentrations. However, the solid waste forms have not yet been determined, and therefore the dissolution rates of the solid waste are unknown.

Determination of radionuclide solubility limits provides an upper bound on radionuclide concentrations in solution and provides a basis for "extrapolation to long-term behavior." The rate of groundwater flow through the waste is expected to be sufficiently slow to permit saturation of water with radionuclides. Dissolution limited by saturation will provide maximum concentration limits. Therefore, an assessment of radionuclide release rates using a saturationlimited dissolution model represents the most conservative approach possible.

As radionuclides are transported along flow paths to the accessible environment, changing conditions of the water ( $\mathrm{pH}, \mathrm{Eh}$, and concentrations of complexing species) can alter solubilities. Decreases in solubility can decrease radionuclide concentrations. A knowledge of radionuclide solubilities under the conditions along possible flow paths is necessary to assess this scenario. Solubility studies are very time-consuming because long times are often needed to reach equilibrium. Because we cannot investigate every possible solubility scenario, we selected $\mathrm{pH}$ and temperature values to bracket the expected range of conditions by choosing parameters that represent lower and upper limits.

Neptunium, plutonium, and americium are expected to be sparingly soluble with solubilitylimited dissolution. Water samples with compositions that bracket the range of waters expected in the vicinity of Yucca Mountain were chosen for solubility measurements. ${ }^{4}$ These samples come from two sources. Water from Well J-13 is a reference water for the unsaturated zone near the proposed emplacement area. Well UE-25p \#1 taps the carbonate aquifer that underlies the emplacement horizon. This water has an ionic strength and total carbonate content higher by approximately an order of magnitude than Well J-13 water. UE-25p \#1 water represents natural water with the highest concentrations of dissolved species expected in the vicinity of Yucca Mountain. The water from both wells is oxidizing. Generally, radionuclide solubility studies under oxidizing conditions lead to higher solubilities for a number of radionuclides than would occur under mildly or strongly reducing conditions. These experiments will therefore provide conservative results. In this study we are reporting on the results in UE-25p \#1 water from overand undersaturation. 
The maximum temperature of the host rock in which liquid water is present is expected to be limited by the boiling point of water at Yucca Mountain $\left(95^{\circ} \mathrm{C}\right)$. The solubility experiments that use Well J-13 water were conducted at temperatures between $25^{\circ}$ and $90^{\circ} \mathrm{C}$. This span covers the range from pre-emplacement temperatures to the maximum temperature at which solubility would be important. For Well UE-25p \#1 water, solubility experiments were limited to a maximum temperature of $60^{\circ} \mathrm{C}$. Maximum temperatures in the saturated zone under the emplacement area and those along the flow paths away from the emplacement area are expected to be less than $60^{\circ} \mathrm{C} .^{5}$

\section{CONCEPT OF SOLUBILITY STUDIES}

Solubility establishes an upper limit for the dissolved components in the source term for radionuclide migration from a repository. Studies of the solubility of radionuclides in groundwaters from a repository horizon will provide limits on their potential concentrations in those waters. Such limits are important for (1) validating an essential part of the radionuclide transport calculations and (2) providing guidance in choosing the maximum starting concentrations for radionuclide sorption experiments. Compared with multi-parameter transport models, laboratory solubility experiments are controlled by fewer variables. If geochemical codes such as EQ3/6 are to be included in the transport model, the model should be capable of predicting the results of solubility experiments.

Complete solubility experiments should provide detailed knowledge of (1) the nature and chemical composition of the solubility-controlling solid, (2) the concentration of the components in solution, and (3) the identity and electrical charge of the species in the solution phase.

Meaningful thermodynamically defined solubility studies must satisfy four criteria: (1) attainment of equilibrium conditions; (2) determination of accurate solution concentrations; (3) attainment and identification of a well-defined solid phase; and (4) knowledge of the speciation/oxidation state of the soluble species at equilibrium.

\subsection{Oversaturation and Undersaturation}

Ideally, solubility experiments should approach solution equilibrium from both oversaturation and undersaturation. The approach from oversaturation consists of adding an excess amount of the element in soluble form to the aqueous solution and then monitoring the precipitation of insoluble material until equilibrium is reached. The solid formed must then be isolated and 
characterized. The approach from undersaturation consists of dissolving the same well-defined solid in an aqueous solution until equilibrium is reached. In both cases, the solution concentration is measured as a function of time until equilibrium is reached.

Kinetic processes will control the equilibration speed in solubility experiments. Some solutions equilibrate rapidly, others more slowly. It must be demonstrated that equilibrium is reached. This can be accomplished by experimentally determining (for both oversaturation and undersaturation experiments) the solution concentration as a function of time. When the concentration stays constant for several weeks, it is assumed that equilibrium has been established. Because this assumption is based on judgment, the term "steady-state" instead of "equilibrium" is more precise. The U.S. Nuclear Regulatory Commission (U.S. NRC) defines "steady-state," as "the conditions where measurable changes in concentrations are not occurring over practical experimental times." 3 At steady state, thermodynamic forces may still change the solution composition: solids may become less soluble as they change from a higher to a lower free energy. The change may be controlled by kinetics and may therefore be very slow and may not show in the experiment even after several years. These infinitesimal changes may require infinite experimental times. The steady-state solids formed in the experiments may therefore not represent the thermodynamically most stable solids with the lowest possible solubilities, but metastable solids having higher solubilities than the thermodynamically defined solids. The term "steady-state" implies this condition.

Despite this constraint, time-limited laboratory solubility experiments can supply valuable information. They provide good estimates on the upper limit of radionuclide concentrations in solution because the experimentally determined steady-state concentrations are higher than the equilibrium concentrations.

A reliable method of proving that an equilibrium has been reached is to approach steady-state from both oversaturation and undersaturation. When these two experimental approaches independently produce equal solution concentrations, the data are considered reliable. For unknown solubility systems, one should first perform experiments approaching steady-state concentration from oversaturation and then characterize the solids. This has the advantage of not specifying the solid that controls solubility but of allowing the system under investigation to determine the solid that will precipitate. These solids can then be used in confirmation experiments that approach steady-state from undersaturation. In this study we are reporting results for both the oversaturation and undersaturation experiments. 


\subsection{Phase Separation}

The second criterion for meaningful solubility experiments is the derivation of accurate solution concentrations. This requires that phase separations must be as complete as possible. The separation of the solid from the solution often represents a significant practical problem in measuring solubility. Apparently higher or lower solubilities, compared with the steady-state values, can result from incomplete phase separation or from sorption of solute during and after the separation. Incomplete phase separations (leaving some of the solid with the solution phase) lead to higher radionuclide solubilities. Lower solubilities are measured if constituents of the steady-state solution have been sorbed on filters during a filtration and on container walls after the separation.

Experimentally, the solids and solutions are separated on the basis of differences in size (via filtration) or density (via sedimentation or centrifugation). Filtration is the more commonly applied technique because it physically partitions the solute and solids. Ultrafiltration (i.e., filtration using membranes $\leq 0.1 \mu \mathrm{m}$ ) can effectively remove solids and colloidal particles from aqueous solution. A potential problem with ultrafiltration is adsorption of soluble species on filtration membranes. Effective filters for solubility studies must pass soluble species quantitatively; that is, either the filter should have no active sorption sites at all or any such sites should be irreversibly blocked. Filters are adequate if they have a small enough pore size to retain the solids and colloids and if they also show no sorption or only minimal sorption during multiple filtrations. Because adsorption of soluble radionuclide species on filters can be dependent on the solution's $\mathrm{pH}$ and on the solution species, it is mandatory to verify that possible sorption sites are indeed blocked. Usually the sorptive sites on a filter and filter housing are blocked by preconditioning of these materials. The filter is preconditioned by filtering a volume of the respective radionuclide solution through it and then discarding the filtrate. The volume required for preconditioning is determined experimentally. Details for this procedure are given in Section 4.5 Phase Separation.

\subsection{Solid Phase}

Solubility depends strongly on the state of the solid phase. Thermodynamically meaningful results require the existence of a well-defined solid phase, which ideally consists of crystalline material. The solids formed from the oversaturation in solubility tests must be clearly identified by physical or chemical characterization methods. Radionuclide solids formed in laboratory experiments and in nature are often thermodynamically ill-defined amorphous precipitates. Most amorphous solids, however, will become more crystalline with time. Freshly precipitated 
microcrystalline solids can also convert in time to a macrocrystalline material. Improved bonding at the lattice surface results in decreasing surface area. Thus the crystalline solid of higher free energy changes to one of lower free energy (Ostwald ripening, Ostwald step rule) and becomes less soluble. ${ }^{6,7,8,9}$

\subsection{Determination of Oxidation States and Speciation}

Information on oxidation states and speciation of the radionuclides in steady-state solubility solution is important for transport models simulating migration and sorption along the flow path to the accessible environment. The charge and speciation of radionuclides will control their sorption and transportation in the geologic host. Speciation measurements identify complexes that may form between radionuclides and complexing ions present in the groundwater near the potential repository. Radionuclides, like all nuclides, can have a single or several different oxidation states in solution. They can be present as simple ions or as complexes. When the ions react with one or several other solution components, they can form soluble complexes.

Oxidation states and speciation in solution are commonly determined by (1) absorption spectrophotometry, (2) ion exchange chromatography, (3) solvent extraction, (4) coprecipitation, (5) potentiometry, and (6) electrochemistry. Of these methods, only absorption spectrophotometry can provide information on speciation, while the others identify only the oxidation state in solution.

Absorption spectrophotometry of Neptunium, Plutonium and Americium in UE-25p \#1 water has a detection limit of about $10^{-5} \mathrm{M}$. This relatively high concentration limits the application of spectrophotometry for speciation determination in solutions from radionuclide solubility studies because the solubilities can be several orders of magnitude below $10^{-6} \mathrm{M}$. Laser-Induced Photoacoustic Spectroscopy (LIPAS) provides much greater sensitivity, approaching $10^{-8}$ to $10^{-9}$ M. $10,11,12,13,14,15$

The methods listed above as 2 through 6 determine only the oxidation state in solution because they cannot determine species. They detect the oxidation state of ions indirectly. This process is different from absorption spectrophotometry, which detects oxidation states and sometimes the solution species directly. The indirect methods, however, detect very small concentrations $\left(10^{-10}\right.$ $\mathrm{M}$ and below), which is useful for radionuclide solubility studies. Solvent extraction and coprecipitation are often used successfully to determine the oxidation states of ions in very dilute solutions. ${ }^{16}$ 
Ion exchange chromatography is less reliable for this purpose because the exchange resin often reduces the solution ions, which gives incorrect results for the oxidation state distribution.

Electrochemical detection reduces or oxidizes the solution ions and measures the potentials of the reduction and oxidation reactions, respectively. The potential then identifies the individual ion. Electrochemistry needs fast kinetics and reversible thermodynamics for the reduction or oxidation step. These experiments greatly limit the method because many radionuclide ion redox reactions are irreversible and slow (e.g., the reactions of $\left.\mathrm{NpO}_{2}^{+} / \mathrm{Np}^{4+}, \mathrm{PuO}_{2}^{+} / \mathrm{Pu}^{4+}\right)^{17}$.

The neptunium solution species were determined by spectrophotometry because the solution concentration was greater than $10^{-5} \mathrm{M}$. The oxidation state of plutonium and americium species in solution were determined by a solvent extraction technique, which is described in principle by Nitsche, et al. ${ }^{16}$ and in detail in Section 5.2.2.

\section{EXPERIMENTAL DETAILS}

We studied the solubilities of neptunium, plutonium, and americium from over- and undersaturation at $60^{\circ} \mathrm{C}$ and $\mathrm{pH}$ values of 6,7 , and 8.5. Measurements were made in an inertatmosphere glovebox to avoid contamination of solutions by atmospheric $\mathrm{CO}_{2}$. The solubilities were studied from oversaturation by injecting a small amount of actinide stock solution into 80 $\mathrm{mL}$ of groundwater obtained from Well UE-25p \#1. The analysis of the water composition is listed in Table IV. 4

Table IV. UE-25p \#1 Groundwater Composition 4

\begin{tabular}{|c|c|}
\hline Species & $\begin{array}{c}\text { Concentration, } \mathrm{mM} \\
7.43\end{array}$ \\
\hline $\mathrm{K}^{+}$ & 0.34 \\
\hline $\mathrm{Ca}^{2+}$ & 2.19 \\
\hline $\mathrm{Mg}^{2+}$ & 1.31 \\
\hline $\mathrm{SiO}_{2}$ & 0.62 \\
\hline $\mathrm{Cl}^{-}$ & 1.04 \\
\hline $\mathrm{SO}_{2}^{2-}$ & 1.34 \\
\hline $\mathrm{F}^{-}$ & 0.18 \\
\hline $\begin{array}{l}\text { Total Alkalinity } \\
\text { Total Carbonate }\end{array}$ & $\begin{array}{l}11.44 \text { mequiv. } / \mathrm{L} \\
15.31\end{array}$ \\
\hline $\begin{array}{l}\text { pH } \\
\text { Eh }(m V)\end{array}$ & $\begin{array}{l}6.7 \\
360\end{array}$ \\
\hline Ionic Strength (mM) & $\sim 20$ \\
\hline
\end{tabular}


The UE-25p \#1 groundwater was obtained at the site by Los Alamos personnel. It was filtered at Los Alamos before it was shipped to LBL. The water's natural carbon dioxide partial pressure $\left(\mathrm{pCO}_{2}\right)$ could not be preserved during filtration and shipping. For the experiments, however, the natural state was induced by re-equilibrating the water with $\mathrm{CO}_{2}$ gas. Details of this procedure are described in Sections 4.3. Pressure Control System, and 4.4. Solutions. Details of the filtration are described in Section 4.4. Solutions. The polyethylene shipping bottle was leached with acid and distilled water prior to its use for the groundwater. The leaching removes possible trace-level contaminants that may alter the composition of the UE-25p \#1 water.

The solubilities were studied from undersaturation by placing the dry, washed solid obtained from the oversaturation experiment into a cell and introducing $80 \mathrm{~mL}$ of a fresh sample of groundwater obtained from Well UE-25p \#1. The carbon dioxide partial pressure $\left(\mathrm{pCO}_{2}\right)$ was maintained in a similar manner to the oversaturation experiments.

\subsection{Controlled-Atmosphere Glove Box}

Due to the $\alpha$-radiation hazard of the actinide elements under investigation, all experimental work was performed in glove boxes. External $\mathrm{CO}_{2}$ control of the experimental solutions requires the exclusion of atmospheric $\mathrm{CO}_{2}$. To satisfy both conditions, we used a controlled-atmosphere glove box.

\subsection{Control System for $\mathrm{pH}$ and Temperature}

Because the solubilities are highly sensitive to $\mathrm{pH}$ and temperature changes, close control of these parameters is necessary. For previous experiments, we had designed a computer-operated control system ("pH-stat") to maintain the aqueous actinide solutions at constant temperatures and $\mathrm{pH}$ values for the solubility experiments. ${ }^{18}$ The $\mathrm{pH}$-stat records and adjusts the $\mathrm{pH}$ values of the experimental solutions (UE-25p \#1 water) at the target values. However, due to frequent deviation from the target $\mathrm{pH}$, the $\mathrm{pH}$-stat began adding excess amounts of acid and base into our solutions. We therefore stopped the automatic addition of acid and base and used the $\mathrm{pH}$-stat to monitor the $\mathrm{pH}$ only. Daily adjustments to the $\mathrm{pH}$ were performed manually, when necessary, and $\mathrm{pH}$ monitoring and data acquisition were continued using the $\mathrm{pH}$-stat system. The temperature of $60^{\circ} \mathrm{C}$ was controlled within less than $1^{\circ} \mathrm{C}$. 


\subsection{Pressure Control System}

We designed and manufactured a pressure regulation system to maintain the well waters used in experiments at their nominal carbonate concentrations when their $\mathrm{pH}$ values are adjusted to conditions differing from their natural state. The system also ensured that no significant evaporative loss of the solutions occurred at elevated temperatures.

\subsection{Solutions}

The actinide stock solutions were prepared by using established methods. ${ }^{19}{ }^{237} \mathrm{~Np}$ (V) stock solutions were prepared by dissolving its oxide in $\mathrm{HCl} .{ }^{239} \mathrm{Pu}(\mathrm{IV})$ stock was prepared from plutonium metal. Stable neodymium(III) was used as an analog for americium(III). ${ }^{1}$ It was prepared by dissolving $\mathrm{Nd}_{2} \mathrm{O}_{3}$ in $\mathrm{HClO}_{4}$. The solution was then spiked with purified ${ }^{241} \mathrm{Am}$ (III) tracer to enable the use of nuclear counting for the determination of the neodymium solution concentrations. Further details for these ${ }^{241} \mathrm{Am} / \mathrm{Nd}$ mixtures are given in Section 5.3. The actinide solutions were purified from possible metal contaminants by ion exchange chromatography. For neptunium and plutonium, anion exchange was used, while cation exchange was employed for americium ${ }^{20}$. The solutions were converted to a non-complexing perchlorate system. The neptunium and plutonium stock solutions were in the +6 oxidation state after their conversion to perchloric acid ( 2 to $3 \mathrm{M}$ ) and were reduced electrolytically to $\mathrm{NpO}_{2}^{+}$ and $\mathrm{Pu}^{3+}$, respectively. $\mathrm{Pu}^{4+}$ was prepared by electrolytic oxidation of pure $\mathrm{Pu}^{3+}$ immediately before the start of the plutonium solubility experiments in order to minimize the disproportionation of $\mathrm{Pu}^{4+} .19,21,22$ Valence purity of the stock solutions was established by absorption spectrophotometry. ${ }^{23,24}$ Oxidation states other than $\mathrm{Pu}(\mathrm{IV})$ were not detected. With our absorption spectrophotometer (Guided Wave Model 260, El Dorado Hills, CA), the limits of detection for $\mathrm{Pu}(\mathrm{III}), \mathrm{Pu}(\mathrm{V})$, and $\mathrm{Pu}(\mathrm{VI})$ are approximately $10^{-4}, 3 \times 10^{-4}$, and $10^{-5} \mathrm{M}$, respectively.

The groundwater was filtered through $0.05 \mu \mathrm{m}$ polycarbonate membrane filters (Nuclepore Corp., Pleasanton, CA). This filtration was carried out by Los Alamos personnel prior to shipping the UE-25p \#1 water sample to LBL. The actinide stock solutions, and all other solutions utilized in this experiment were filtered through $0.22 \mu \mathrm{m}$ polyvinylidene difluoride syringe filter units (Millipore Corp., Bedford, MA). Filtration was used to remove suspended particulate material, e.g., dust or silica, that could absorb the actinide ions to form pseudocolloids. For the oversaturation experiments, before adding between 1 and $4 \mathrm{~mL}$ of the actinide stock solutions to approximately $80 \mathrm{~mL}$ of UE-25p \#1 water, a small amount of $\mathrm{CO}_{2}$-free sodium hydroxide solution was added in order to keep the $\mathrm{pH}$ values at or above the desired solution $\mathrm{pH}$. Letting the 
$\mathrm{pH}$ drop below the target value would necessitate addition of concentrated base to the system while the actinide ion is already present in the solution. Addition of strong base can result in unpredictable microprecipitation and formation of microcolloids.

When we started the neptunium oversaturation experiments, we added small volumes of $5 \mathrm{M}$ sodium hydroxide to the UE-25p \#1 groundwater to neutralize the perchloric acid that would be introduced with the stock solution. We added the acidic stock followed by $1 \mathrm{M}$ perchloric acid, 1 $\mathrm{M}$ sodium hydroxide, or both if necessary, to attain the desired $\mathrm{pH}$ for the experiment. At $\mathrm{pH} 6$, the added acid and base led to additional concentrations of $\mathrm{Na}^{+}$and $\mathrm{ClO}_{4}^{-}$of 53 and $8.9 \mathrm{mM}$, respectively, resulting in a higher initial concentration of $\mathrm{Na}^{+}$by a factor of about 8.2 and an initial ionic strength about 4.9 times higher than that of UE-25p \#1 water. At $\mathrm{pH} 7$, addition of only sodium hydroxide increased the $\mathrm{Na}^{+}$concentration by $9.6 \mathrm{mM}$. This increased the ionic strength by only 25 percent. At pH 8.5, additions of $\mathrm{NaOH}$ and $\mathrm{HClO}_{4}$ increased the respective $\mathrm{Na}^{+}$and $\mathrm{ClO}_{4}^{-}$concentrations by 23 and $7.5 \mathrm{mM}$. This increased the $\mathrm{Na}^{+}$content and the ionic strength by factors of about 4.1 and 1.8 , respectively.

For the plutonium experiments, we also added $5 \mathrm{M} \mathrm{NaOH}$ to the UE-25p \#1 water before we introduced the acidic plutonium stock solution. The additions of acid and base were small and the resulting changes in the water composition were not large. The plutonium stock solution was 7.9 $x 10^{-3} \mathrm{M}$ in total plutonium and $3.0 \mathrm{M}$ in $\mathrm{HClO}_{4}$. At pH 6 and 7 , adjustments led to additional concentrations of $\mathrm{Na}^{+}$and $\mathrm{ClO}_{4}^{-}$of 21 and $80 \mathrm{mM}$, respectively. These additions increased the sodium content and the ionic strength in both experiments by factors of about 3.8 and 3.6 , respectively. For the $\mathrm{pH} 8.5$ experiment, acid and base adjustments led to additional concentrations of $\mathrm{Na}^{+}$and $\mathrm{ClO}_{4}^{-}$of 22 and $95 \mathrm{mM}$, respectively. This increased the $\mathrm{Na}^{+}$content and the ionic strength by factors of about 4.0 and 3.9 , respectively.

For the neodymium/americium experiments, we used even smaller amounts of $5 \mathrm{M} \mathrm{NaOH}$ because the $\mathrm{Nd} / \mathrm{Am}$ stock solution was $1 \mathrm{M}$ in $\mathrm{HClO}_{4}$. At $\mathrm{pH} 6$, addition of acid and base,

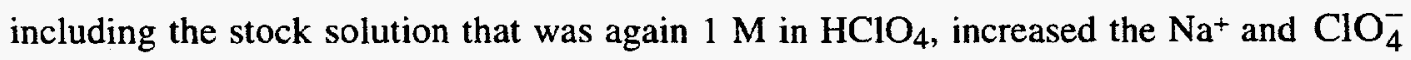
concentrations by 14 and $20 \mathrm{mM}$, respectively. This increased the initial amount of sodium and the ionic strength by factors of about 2.9 and 1.9, respectively. At $\mathrm{pH} 7$, additions increased the $\mathrm{Na}^{+}$and $\mathrm{ClO}_{4}^{-}$concentrations by 15 and $17 \mathrm{mM}$, respectively, increasing the sodium content and the ionic strength by factors of about 3.0 and 1.8 , respectively. At $\mathrm{pH} 8.5$, additions increased the $\mathrm{Na}^{+}$and $\mathrm{ClO}_{4}^{-}$concentrations by 19 and $17 \mathrm{mM}$, respectively. This increased the initial amount of sodium and the ionic strength by factors of about 3.5 and 1.9 , respectively. 
In summary, initial additions of sodium hydroxide and perchloric acid to the neptunium experiments increased the total $\mathrm{Na}^{+}$content by factors that ranged from 2.3 to 8.2 times the original amount found in UE-25p \#1 water and increased the ionic strength of the solutions by factors ranging from 1.3 to 4.9 . Additions of acid and base at the start of the plutonium experiments increased the total $\mathrm{Na}^{+}$content by factors that ranged from 3.8 to 4.0 , resulting in ionic strengths that were higher than that of UE-25p \#1 well water by factors that ranged from 3.6 to 3.9. And for the neodymium/americium experiments, additions of acid and base at the start of the experiments increased the initial sodium content by factors that ranged from 2.9 to 3.5 , resulting in initial ionic strengths higher by factors that ranged from 1.8 to 1.9 .

The well water's total dissolved carbonate $\left(1.531 \times 10^{-2} \mathrm{M}\right)$ was preserved at each individual $\mathrm{pH}$ by equilibrating the solution with mixtures of $\mathrm{CO}_{2}$ in argon. ${ }^{4}$ The amount of $\mathrm{CO}_{2}$ at a given pH and temperature was calculated from Henry's constant and the dissociation constants of carbonic acid from literature data. ${ }^{25}$ If the value at the given temperature was not available, the number was derived by interpolation of adjacent values. Activity coefficients were adjusted for ionic strength using the Davies equation. The concentrations of the equilibration gas mixtures are given in Table $\mathrm{V}$ together with the dissociation constants used to determine them.

The test solutions were kept in $90 \mathrm{~mL}$ cells that were made of Polyether etherketone (PEEK). ${ }^{26}$ All cells had sealed ports at the top that accommodate the permanent emplacement of a $\mathrm{pH}$ electrode, an opening to draw samples, and three 1/16" diameter Teflon lines for addition of acid, base, and the $\mathrm{CO}_{2}$-argon mixture. The temperature was controlled by placing the test cells in a heated aluminum block of LBL design. The electric heater was mounted on an orbital shaker (Lab-Line Inc., Melrose Park, IL), and all solutions were shaken continuously at approximately $100 \mathrm{rpm}$. The solutions' $\mathrm{pH}$ values were monitored by a computer-operated $\mathrm{pH}$ control system (pH-stat, see Section 4.2), and were controlled by hand. Combination $\mathrm{pH}$ electrodes from Broadley-James Corp., Model E-1393EC1-A03BC were used to monitor the solutions pH values. 
Table V. Concentrations (in percent) of carbon dioxide gas in argon to maintain a total dissolved carbonate concentration of $1.531 \times 10^{-2} \mathrm{M}$ in UE-25p \#1 water at different $\mathrm{pH}$ 's together with the values for Henry's constant and the dissociation constants for carbonic acid used to determine the $\mathrm{pCO}_{2}$ values.

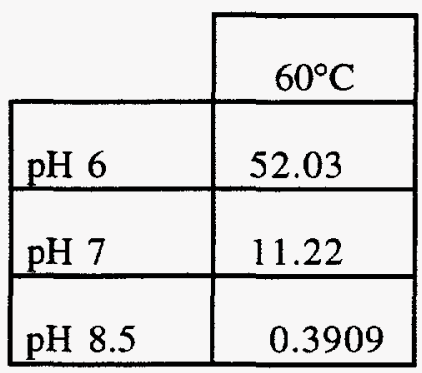

\begin{tabular}{|c|c|}
\cline { 2 - 2 } \multicolumn{1}{c|}{} & $60^{\circ} \mathrm{C}$ \\
\hline $\mathrm{pK}_{\mathrm{H}}$ & 1.77 \\
\hline $\mathrm{pK}_{1}$ & 6.17 \\
\hline $\mathrm{pK}_{2}$ & 9.91 \\
\hline
\end{tabular}

The combination $\mathrm{pH}$ electrodes from Broadley-James Corp. were used in the experiments because of their expectedly better long-term $\mathrm{pH}$ stability. These electrodes, however, went out of calibration quite often and the computer controlled monitoring of the $\mathrm{pH}$ showed deviations of up to 0.2 units. These deviations were the result of the electrode's going out of calibration, and not a result of the instability of the experimental equilibria. Therefore, we did not use the $\mathrm{pH}$-stat for $\mathrm{pH}$ adjustment. We calibrated the electrodes often and only adjusted the solution's $\mathrm{pH}$ by hand after each calibration. The deterioration of the electrode is mainly due to the dissolution of the $\mathrm{Ag} / \mathrm{AgCl}$ layer of the reference electrode wire and also of the wire used in the $\mathrm{pH}$ sensing compartment itself; the solubility of $\mathrm{AgCl}$ increases approximately 240 times when the temperature changes from $10^{\circ}$ to $100^{\circ} \mathrm{C}$. Although the manufacturer claims the working range of these electrodes is up to $100^{\circ} \mathrm{C}$, we were unable to use the electrodes continuously with $\mathrm{pH}$-stat computer controlled $\mathrm{pH}$ adjustment. Therefore, we allowed $\mathrm{pH}$-stat to continuously monitor the $\mathrm{pH}$, but we performed the $\mathrm{pH}$ adjustment by hand.

The effect on the composition of the UE-25p \#1 groundwater due to the addition of acid and/or base during the experiment is a rather complicated one. At the start of the oversaturation experiments, the ionic strengths of the solutions were increased by factors that ranged from 1.3 to 4.9 simply with the introduction of the actinide stock solutions and the sodium hydroxide needed to neutralize the perchloric acid in the stock solutions. Therefore, the initial ionic strengths ranged from $\sim 0.03$ to $0.1 \mathrm{M}$. During the course of the solubility experiments, $0.1 \mathrm{M}$ perchloric acid and sodium hydroxide were used to maintain the desired $\mathrm{pH}$ of the solubility experiments. Also during that time, we assayed the solutions for concentration and speciation determinations. The volumes of acid and base added to the experiments ranged from 2 to over $20 \mathrm{~mL}$; whereas, to perform all of the concentration and speciation determinations throughout the experiment, we removed $\sim 30$ to $50 \mathrm{~mL}$ of solution. The net effect on $70 \mathrm{~mL}$ of an initially $0.04 \mathrm{M}$ solution in 
removing $50 \mathrm{~mL}$ for assays and then adding $20 \mathrm{~mL}$ of $0.1 \mathrm{M}$ acid and/or base solutions to adjust the $\mathrm{pH}$ would result in increasing the ionic strength to approximately $0.07 \mathrm{M}$. For solutions that were initially $0.1 \mathrm{M}$, they would remain at roughly the same ionic strength. Therefore, in these cases we would have final ionic strengths that range from $\sim 0.07$ to $0.1 \mathrm{M}$. In all cases, however, the constituents in UE-25p \#1 groundwater other than sodium (and perchlorate) would be diluted by roughly a factor of 7 . Of course the solutions to which we added very little acid and/or base, the final ionic strengths will be closer to their initial ionic strengths. The addition of acid and/base, however, ran concurrently with the removal of solution volumes for assays, so it is rather difficult to establish exactly the true ionic strength of these solutions at the conclusion of the experiments.

The addition of acid and base to the solutions during the course of the experiments appears to have had an averaging effect on the ionic strength of the solutions when compared with the effect of introducing the actinide stock solutions. Upon starting the experiments, the ionic strengths ranged from $\sim 0.03$ to $0.1 \mathrm{M}$, but by adding $0.1 \mathrm{M}$ solutions of acid and base during the course of the experiments, we narrowed that range. With an approximate analysis based on final volumes, we can only say that the final ionic strengths in all of the solubility experiments were probably closer to $0.1 \mathrm{M}, \pm 50 \%$, and that the primary constituents are sodium and perchlorate. This five fold increase in the ionic strength of UE-25p \#1 groundwater definitely shows the difficulties in trying to maintain constant solution conditions in long term solubility experiments such as these.

\subsection{Phase Separation}

Achievement of steady-state conditions for the solubility measurements was monitored by sampling aliquots of the solution phases and analyzing for the respective radioisotope as a function of time. We used Centricon-30 centrifugal filters (Amicon Corp., Danvers, MA) for separating the phases of the neptunium, plutonium, and americium solutions. For the separations, the centrifuge (High-speed centrifuge, Model HSC-1000, Savant Instruments Inc.) was heated with a circulating water bath to $60^{\circ} \mathrm{C}$. The filters contain a YM-type membrane with a calculated pore size of $4.1 \mathrm{~nm}^{27}$. To ascertain that we achieved complete phase separation and minimal adsorption on the filters during the preparation of the solution assays, we conducted a series of filtration tests.

For each solution, these tests were done at different times during the equilibration period. We used one filter per solution and filtered consecutive $500 \mu \mathrm{L}$ portions of solution through it. Each filtrate was acidified to minimize sorption in the filtrate-collection container and an assay was taken. The concentration was plotted as a function of total volume passed through the filter. This was repeated until the assays showed a constant concentration. The volume necessary to saturate 
the filter was the cumulative amount of volumes used until the assay concentration remained constant. The presaturation volume was radionuclide-dependent.

We determined and used the following preconditioning volumes: $500 \mu \mathrm{L}, 500 \mu \mathrm{L}$, and $2500 \mu \mathrm{L}$ for the neptunium, plutonium, and neodymium/americium solutions, respectively.

\subsection{Analysis}

After separation of the solution and the solid phases, the two components were analyzed separately. Concentration measurements of the supernatants were made by counting liquid aliquots with a germanium low-energy counting system (LBL design). For ${ }^{237} \mathrm{~Np}$ and ${ }^{241} \mathrm{Am}$, the $29.38 \mathrm{keV}$ and $59.54 \mathrm{keV}-\gamma$-ray lines were used, respectively. ${ }^{239} \mathrm{Pu}$ was analyzed by utilizing the $\mathrm{U} L \mathrm{x}$-rays coming from the $\alpha$-decay of the plutonium. Possible contributions to the $L \mathrm{x}$-rays from the decays of other radionuclides, also present in small amounts, were corrected by subtraction. ${ }^{28}$ In selected cases, liquid scintillation counting was also used for plutonium concentration determinations (LKB Instruments, Inc., Wallac Oy, Model 1219 RackBeta). We used the "Pulse Shape Analysis" feature of the 1219 RackBeta to discriminate all $\beta$-emitting solution contaminants from the plutonium $\alpha$-radiation. Repeated sample counting and the observation of a constant count rate in the $\alpha$-window ensured no $\beta$-contribution to the $\alpha$-count.

\subsection{Criteria for Steady-State Concentrations}

Constant concentrations over time with minimal deviation during that time span are the criteria for determining the average steady-state concentration from the individual concentration measurements. For experiments in which the aqueous concentration continually increases (or decreases), the final steady-state concentration will be equal to the final concentration measurement taken from the experiment. This concentration may not be the actual steady-state concentration, and all that can be stated is that the steady-state concentration is probably greater than (or less than) or equal to the value reported.

\subsection{Eh Measurements}

We are aware of the problems associated with Eh measurements in groundwater systems.

Lindberg and Runnells ${ }^{29}$ point out that in the apparent absence of an internal redox equilibrium, as is the case for many groundwater systems, Eh measurements may not accurately predict the equilibrium chemistry of the system. Because our experimental systems contained a very limited number of components and may be well poised, we measured the Eh at the end of each solubility 
experiment. In several cases, we obtained stable readings only after measuring as long as 24 hours. This drifting does not lend much confidence in the obtained Eh value. Despite these limitations, we conducted these measurements in order to supply future chemical modeling efforts (neptunium, plutonium, and americium solubilities in UE-25p \#1 water solutions) with an approximate value indicating the general oxic nature of the system. Without modeling, however, the Eh measurements are only of limited value, because they may represent a combination of many different redox reactions for each individual solubility solution despite the limited number of components.

We measured the Eh with a platinum electrode versus a $\mathrm{Ag} / \mathrm{AgCl} / \mathrm{sat} . \mathrm{NaCl}$ reference. We cleaned the platinum electrode with $6 \mathrm{M} \mathrm{HNO}_{3}$ before and after each measurement. The electrode setup was checked with "Zobell Solution" before and after each measurement. ${ }^{30,31}$

\subsection{Identification of Solids}

The solid compounds were analyzed by x-ray powder diffraction measurements. A few micrograms of each actinide precipitate were placed in a $0.33 \mathrm{~mm}$ diameter quartz capillary tube, and the tube was sealed with an oxy-butane microtorch. The tube was mounted in an $11.46 \mathrm{~cm}$ diameter Debye-Scherrer camera and then irradiated with $\mathrm{x}$-rays from a Norelco III $\mathrm{x}$-ray generator (Phillips Electronics, Inc.). Copper $\mathrm{K}_{\alpha}$ radiation filtered through nickel was used.

\section{RESULTS AND DISCUSSION}

5.1. Neptunium. 5.1.1. Solubility. The comparison of the steady-state concentrations of both the over- and undersaturation neptunium experiments are shown in Figure 1. For the oversaturation experiments the neptunium was initially introduced as $\mathrm{NpO}_{2}{ }^{+}$into the UE-25p \#1 groundwater. For the undersaturation experiments, the solids formed from oversaturation were added to fresh solutions of UE-25p \#1 groundwater. The steady-state concentrations and the solutions' Eh values are given in Table VI. Both the neptunium over- and undersaturation experiments provided the same steady-state solution potentials within the uncertainties of the measurement. For both experiments, the $\mathrm{pH} 6$ solubility experiment had the highest redox potential and the $\mathrm{pH} 8.5$ solubility experiment had the lowest potential. Concentration profiles as a function of equilibration time and $\mathrm{pH}$ for both over- and undersaturation experiments are shown in Figure 2 . The individual measurements are listed in Appendix A. We experienced some difficulties with the neptunium undersaturation cell at $\mathrm{pH}$ 6. Near day 189 of this experiment we measured a $\mathrm{pH}$ of 7.00. This rise in $\mathrm{pH}$ precipitated some of the aqueous neptunium and lowered the soluble neptunium concentration. At this point, we restarted the undersaturation experiment by removing 
the solid phase and placing it in fresh UE-25p \#1 water at $\mathrm{pH} 6$. We kept it at this $\mathrm{pH}$ for the remainder of the experiment. The aqueous concentration of neptunium did not increase back to the concentration before the $\mathrm{pH}$ increase. There was a slight increase in the aqueous concentration, but with time the concentration leveled off to a steady-state value midway between the $\mathrm{pH} 6$ and $\mathrm{pH} 7$ steady-state concentrations. At the point that the $\mathrm{pH}$ increase was first discovered, we removed a small portion of the solid phase for $\mathrm{x}$-ray analysis. The powder pattern obtained was different from both those obtained in the $\mathrm{pH} 6$ and $\mathrm{pH} 7$ oversaturation experiments, and contained nearly twice as many diffraction lines. The fact that the solid phase removed from the second undersaturation experiment remained in contact with the UE-25p \#1 water at pH 6 for nearly 400 days, combined with the lower solubility and the different powder pattern, suggests that a different, more crystalline solid phase formed with a more thermodynamically stable crystal lattice which led to lower solubilities in the groundwater.

Results from neptunium filtration experiments have been given elsewhere. ${ }^{32}$ The filtration experiments are described in Section 4.5. We found no volume effect for the neptunium in either the over- or undersaturation experiments. We therefore used $500 \mu \mathrm{L}$ of solution as presaturation volume for routine separations. 


\section{Neptunium(V) Solubility Experiments from Over- and Undersaturation in UE-25p\#1 Water at $60^{\circ} \mathrm{C}$}

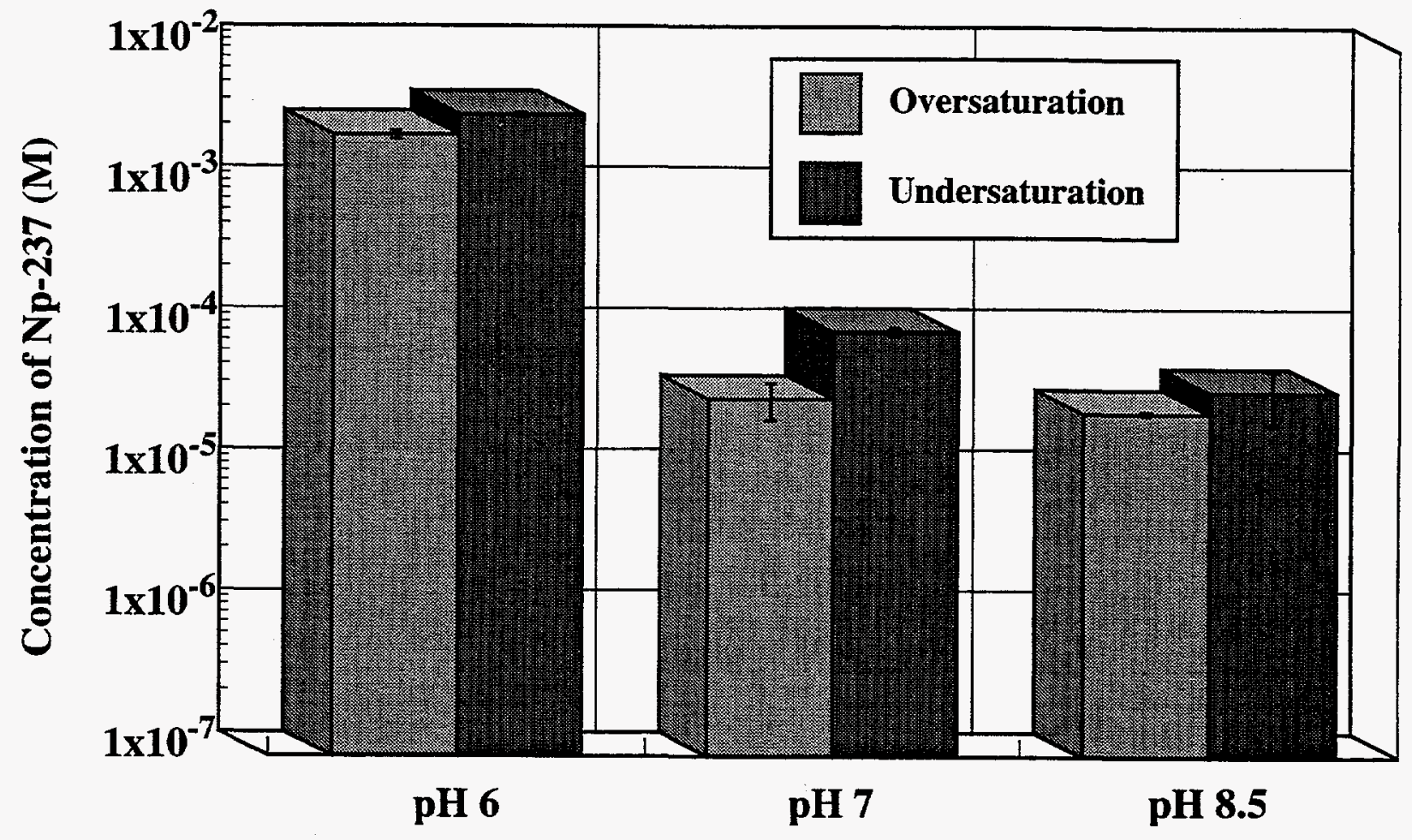

Figure 1. Results of the neptunium solubility experiments from over- and undersaturation in UE-25p \#1 groundwater as a function of $\mathrm{pH}$.

Table VI. Comparison of steady-state solution concentrations and Eh for neptunium overand undersaturation experiments in UE-25p \#1 groundwater at $60^{\circ} \mathrm{C}$.

\begin{tabular}{|c|c|c|c|c|}
\hline \multirow{2}{*}{$\mathrm{pH}$} & \multicolumn{4}{|c|}{ Neptunium(V) } \\
\cline { 2 - 5 } & \multicolumn{3}{|c|}{ Concentration $(\mathrm{M})$} & \multicolumn{2}{c|}{ Eh (mV vs. NHE) } \\
\cline { 2 - 5 } & Oversaturation & Undersaturation & Oversaturation & Undersaturation \\
\hline 6 & $(2.5 \pm 0.2) \times 10^{-3}$ & $(3.4 \pm 0.1) \times 10^{-3}$ & $(414 \pm 15)$ & $(406 \pm 15)$ \\
\hline 7 & $(3.4 \pm 1.0) \times 10^{-5}$ & $(1.0 \pm 0.1) \times 10^{-4}$ & $(367 \pm 15)$ & $(366 \pm 15)$ \\
\hline 8.5 & $(2.7 \pm 0.1) \times 10^{-5}$ & $(3.8 \pm 1.6) \times 10^{-5}$ & $(212 \pm 15)$ & $(239 \pm 15)$ \\
\hline
\end{tabular}




\section{Approach to Equilibrium from Over- and Undersaturation of UE-25p\#1 Water Solutions of $\mathrm{Np}(\mathrm{V})$ at $60^{\circ} \mathrm{C}$}

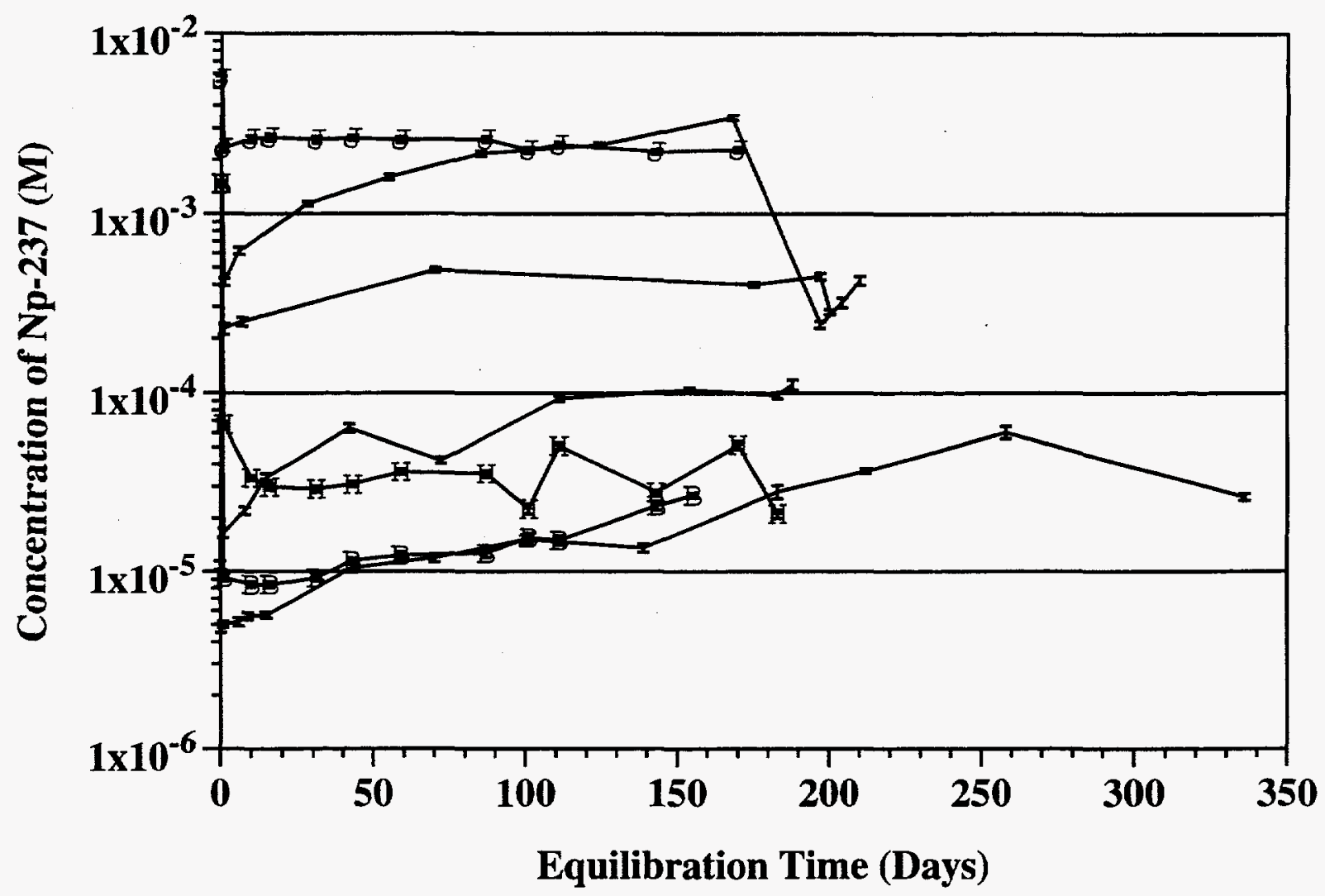

Figure 2. Solution concentrations of ${ }^{237} \mathrm{~Np}$ in contact with precipitate obtained from supersaturation of UE-25p \#1 groundwater at $60^{\circ} \mathrm{C}$ as a function of time. $\mathrm{pH}$ $6.0 \pm 0.1$ (closed circles), $\mathrm{pH} 7.0 \pm 0.1$ (closed triangles), and $\mathrm{pH} 8.5 \pm 0.1$ (closed squares). The neptunium was added initially (day 0 ) as $\mathrm{NpO}_{2}{ }^{+}$; initial concentrations were $5.6 \times 10^{-3} \mathrm{M}(\mathrm{pH} 6), 1.5 \times 10^{-3} \mathrm{M}(\mathrm{pH} 7)$, and $1.5 \times 10^{-3}$ $\mathrm{M}$ (pH 8.5). Undersaturation experiments at $\mathrm{pH} 6.0$ (open circles, open diamonds), $\mathrm{pH} 7.0$ (open triangles), and $\mathrm{pH} 8.5$ (open squares) were started with precipitates obtained in the supersaturation experiments at their respective $\mathrm{pH}$ values. 
In summary, the neptunium solubility decreased with increasing $\mathrm{pH}$ in both the over- and undersaturation experiments. All of the undersaturation cells had steady-state aqueous neptunium concentrations slightly higher than the steady-state concentrations from oversaturation. However the steady-state concentrations from over- and undersaturation agreed to within an order of magnitude.

5.1.2. Speciation. The supernatant solutions from the neptunium solubility experiments were analyzed by absorption spectrophotometry to determine the oxidation state and speciation. The spectra for the $60^{\circ} \mathrm{C}$ oversaturation experiments at $\mathrm{pH} 6,7$, and 8.5 are shown in Figures 3, 4, and 5 , respectively. The spectra for the $60^{\circ} \mathrm{C}$ undersaturation experiments at $\mathrm{pH} 6,7$, and 8.5 are shown in Figures 6, 7, and 8, respectively. The solutions underwent phase separation in a centrifuge heated to $60^{\circ} \mathrm{C}$; however, the quartz cuvettes used for the spectral measurements were not thermostated. Even though spectral measurements were made immediately after the separation, the supernatant solutions may have cooled slightly before finishing the measurements. Depending on the $\mathrm{pH}$, the spectra show either the $\mathrm{NpO}_{2}{ }^{+}$main absorption band at $980.6 \mathrm{~nm}$ and/or an

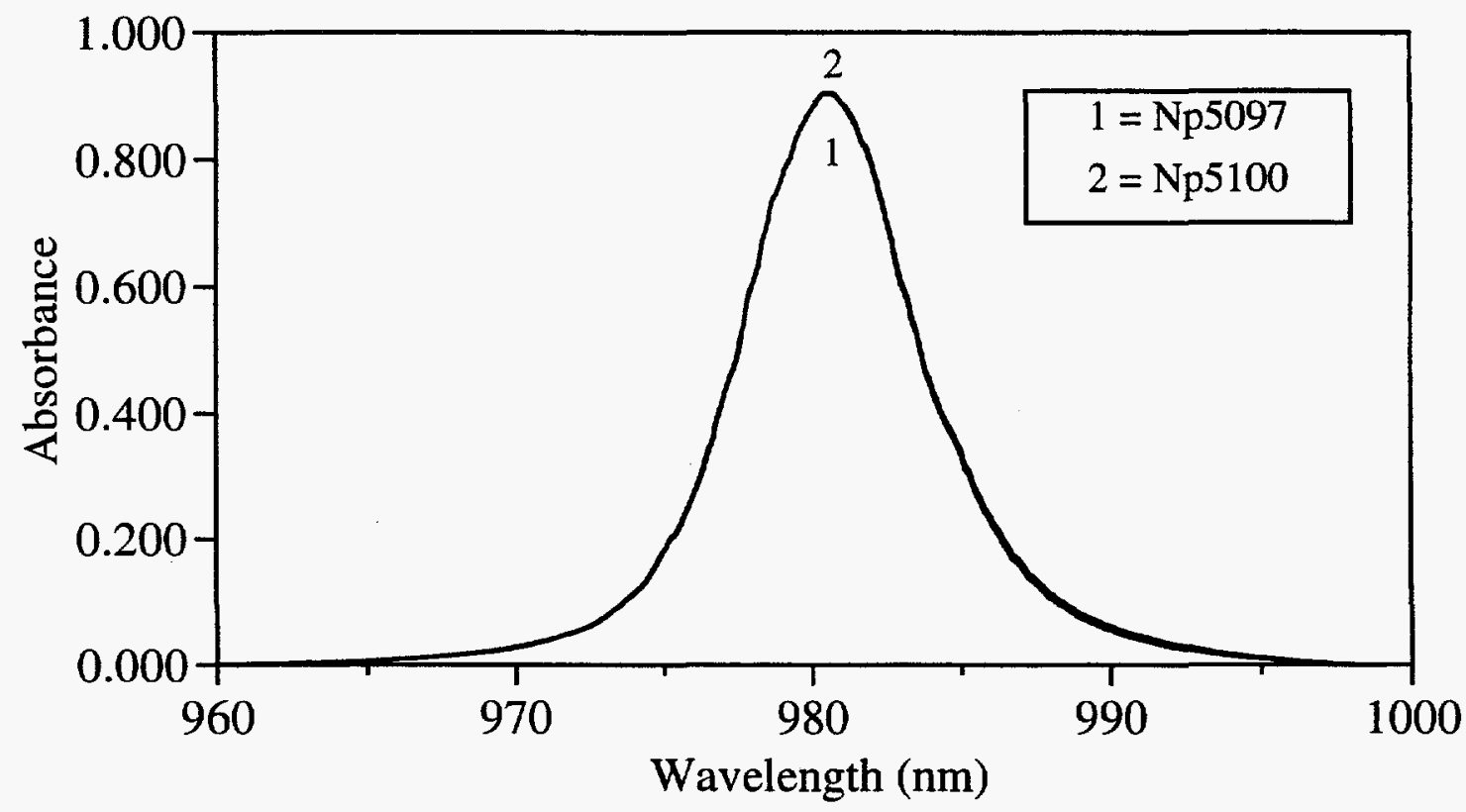

Figure 3. Near-IR absorption spectra of Np supernatant solutions at steady-state formed in UE-25p \#1 groundwater from oversaturation at $60^{\circ} \mathrm{C}$ in $\mathrm{pH} 6:$ (1) at the experimental $\mathrm{pH}$ and (2) after acidification with $\mathrm{HClO}_{4}$ to $\mathrm{pH} 2$. 


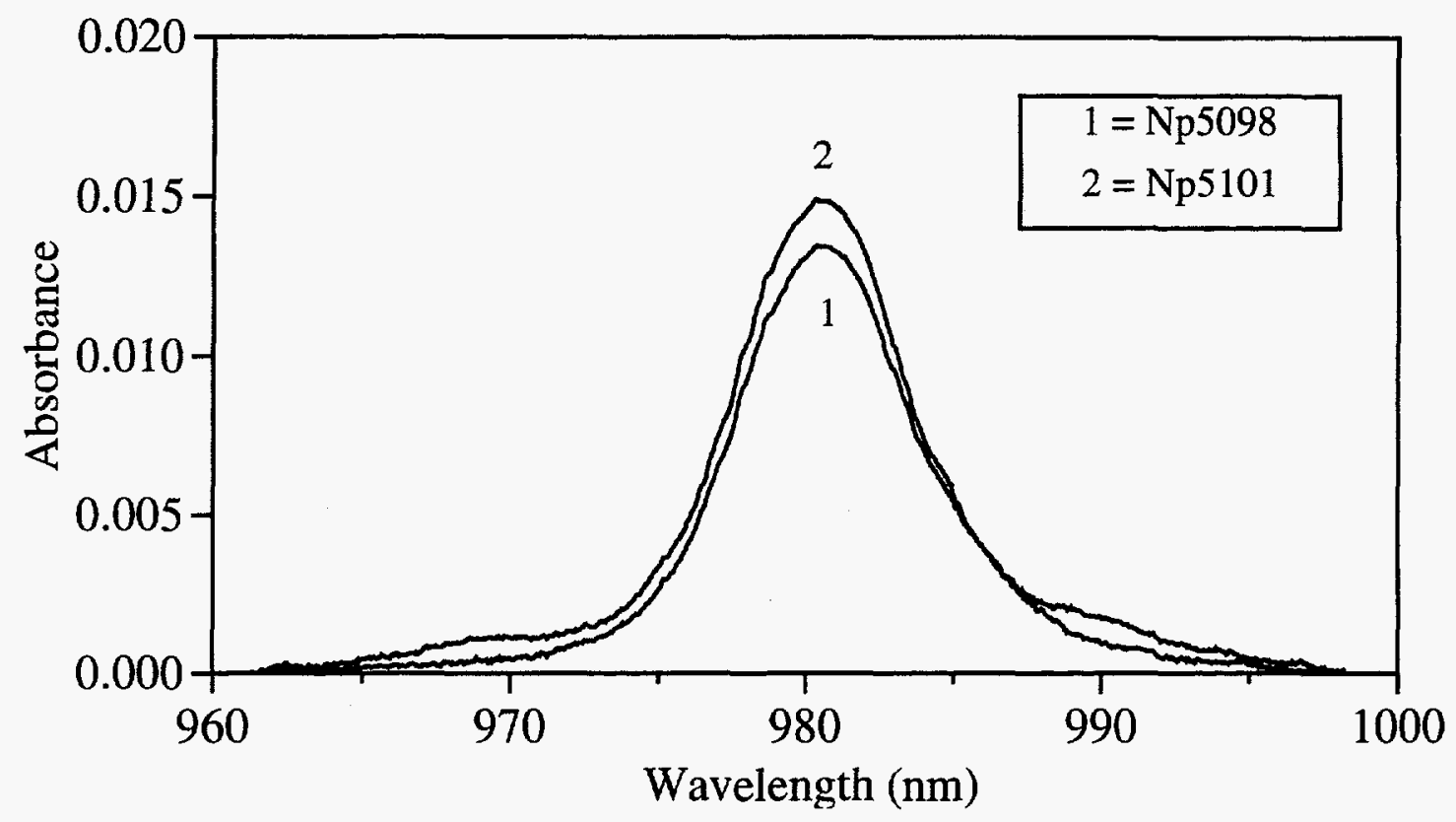

Figure 4. Near-IR absorption spectra of Np supernatant solutions at steady-state formed in UE-25p \#1 groundwater from oversaturation at $60^{\circ} \mathrm{C}$ in $\mathrm{pH} 7$ : (1) at the experimental $\mathrm{pH}$ and (2) after acidification with $\mathrm{HClO}_{4}$ to $\mathrm{pH} 1$.



Figure 5. Near-IR absorption spectra of Np supernatant solutions at steady-state formed in UE-25p \#1 groundwater from oversaturation at $60^{\circ} \mathrm{C}$ in $\mathrm{pH} 8.5$ : (1) at the experimental $\mathrm{pH}$; (2) after acidification with $\mathrm{HClO}_{4}$ to $\mathrm{pH} 1$. 


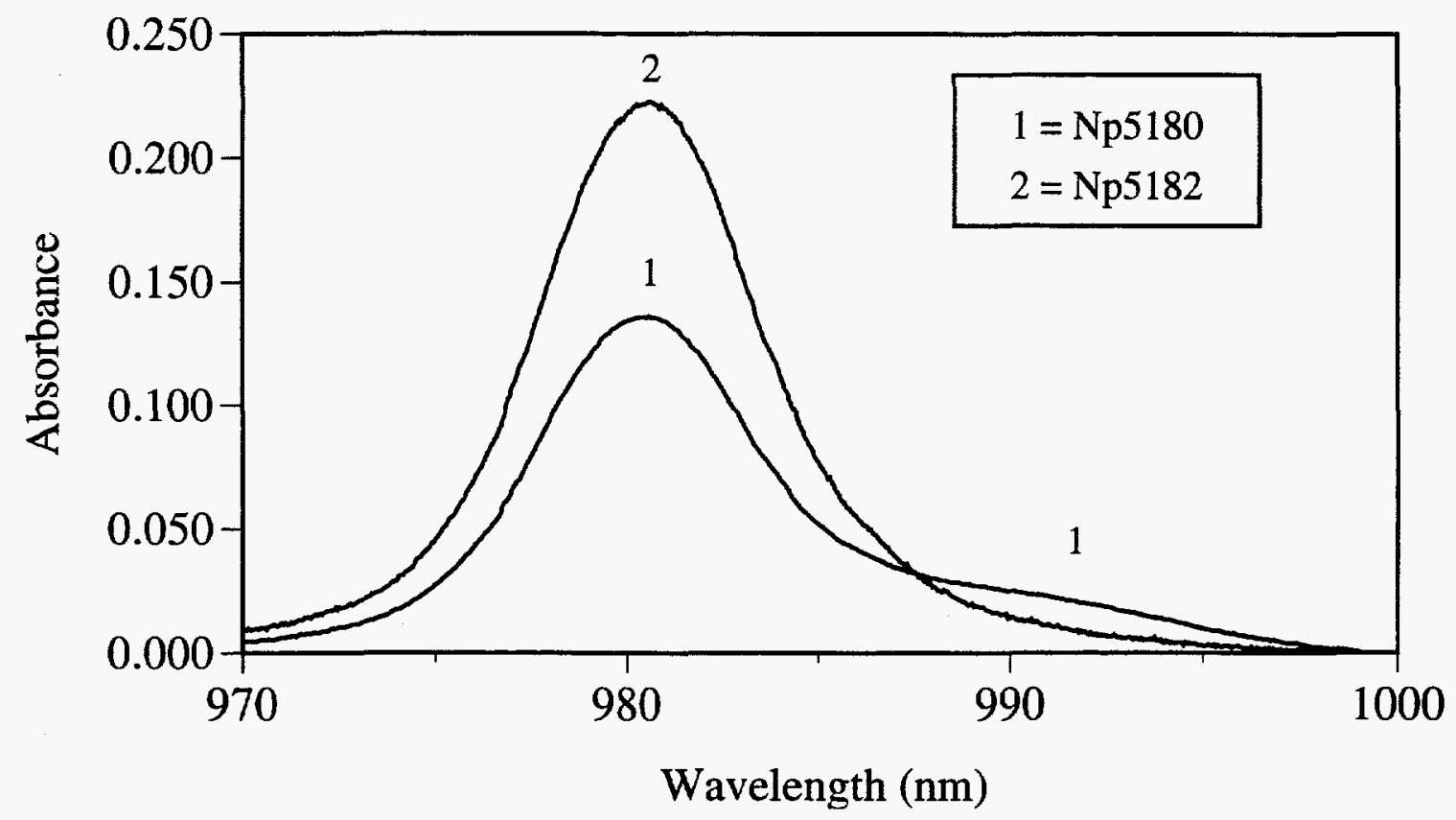

Figure 6. Near-IR absorption spectra of Np supernatant solutions at steady-state formed in UE-25p \#1 groundwater from undersaturation at $60^{\circ} \mathrm{C}$ in $\mathrm{pH} 6$ : (1) at the experimental $\mathrm{pH}$; (2) after acidification with $\mathrm{HClO}_{4}$ to $\mathrm{pH} 0$.

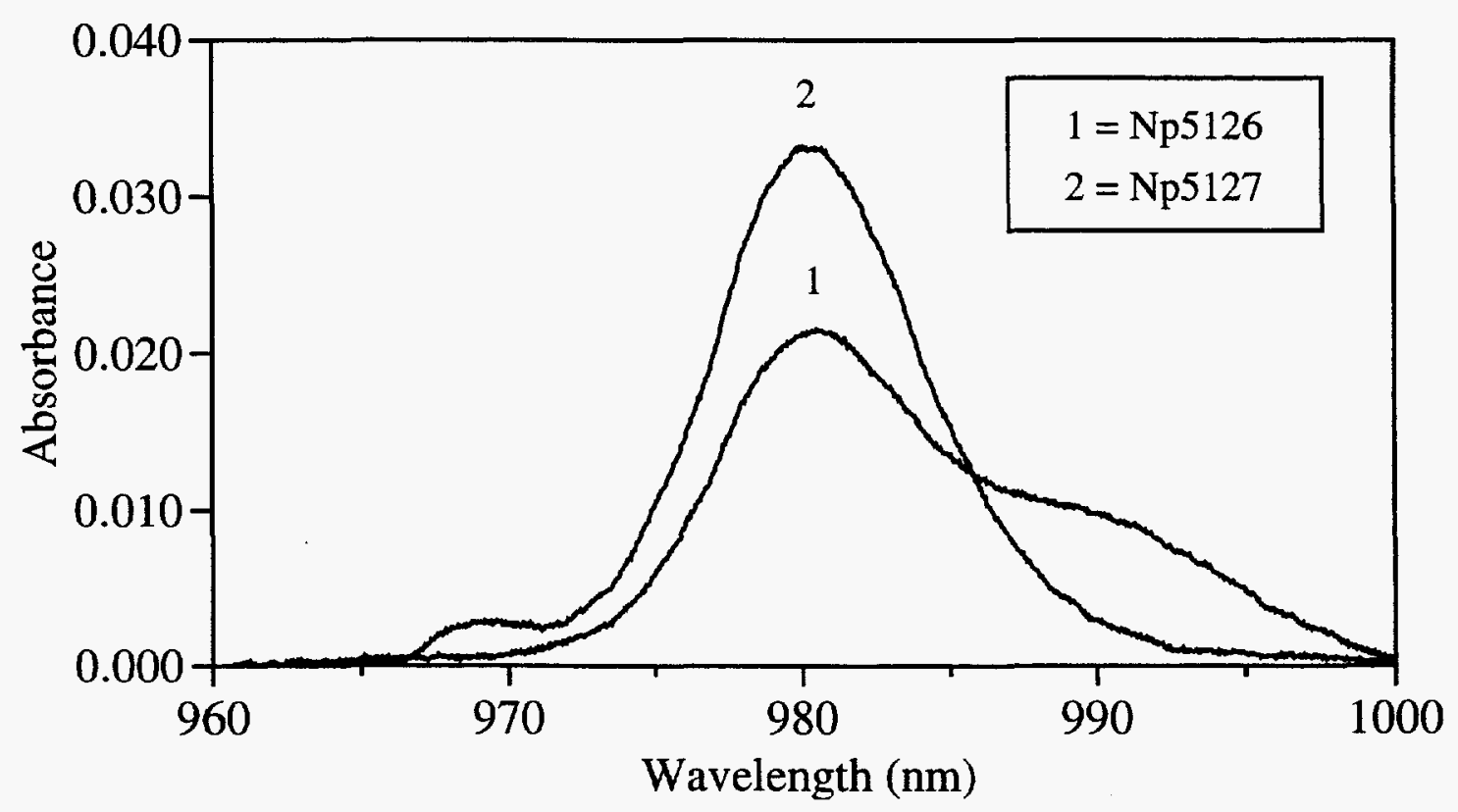

Figure 7. Near-IR absorption spectra of Np supernatant solutions at steady state formed in UE-25p \#1 groundwater from undersaturation at $60^{\circ} \mathrm{C}$ in $\mathrm{pH} 7$ : (1) at the experimental $\mathrm{pH}$; (2) after acidification with $\mathrm{HClO}_{4}$ to $\mathrm{pH} 0$. 


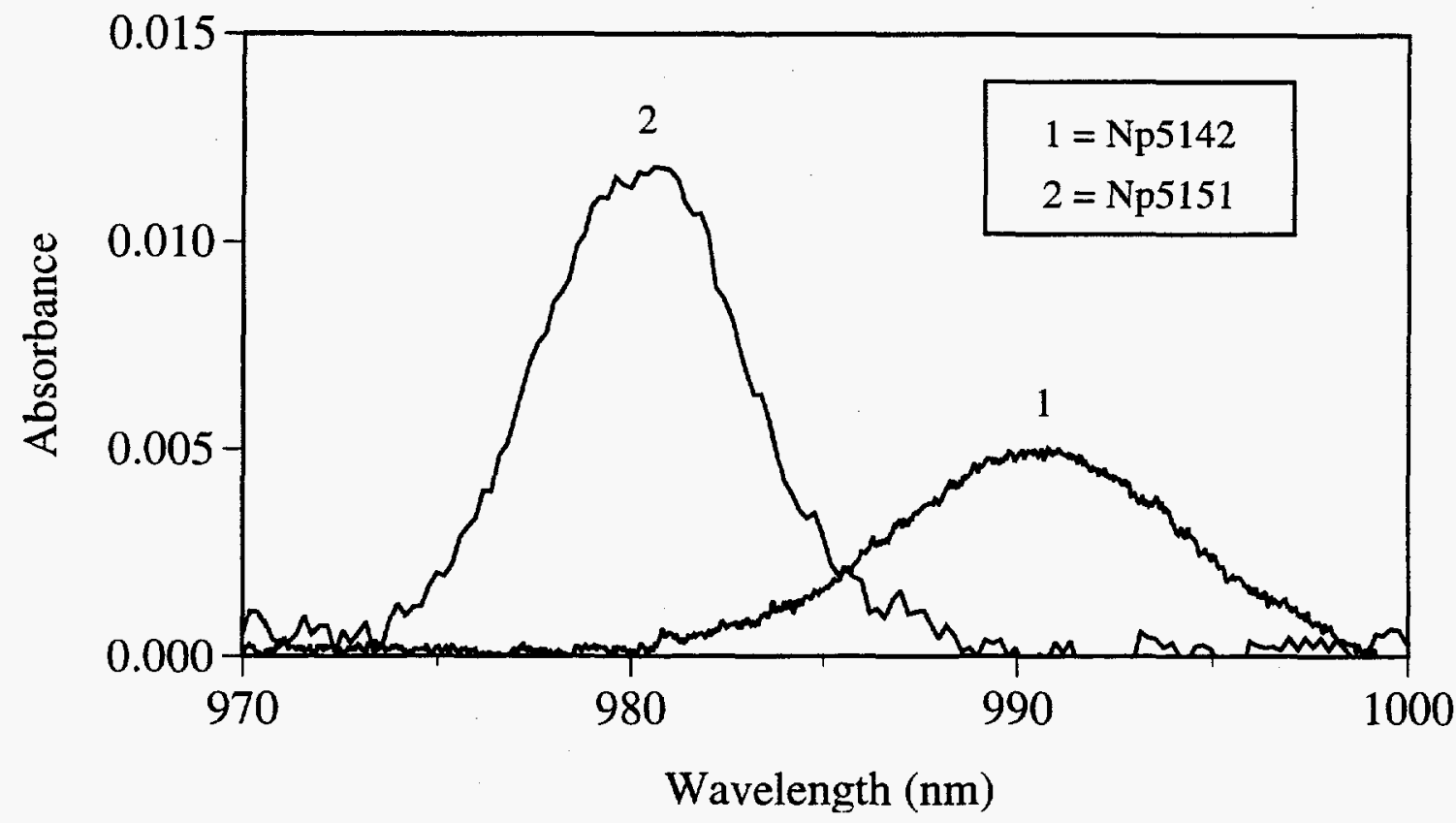

Figure 8. Near-IR absorption spectra of Np supernatant solutions at steady-state formed in UE-25p \#1 groundwater from undersaturation at $60^{\circ} \mathrm{C}$ in $\mathrm{pH} 8.5$ : (1) at the experimental $\mathrm{pH}$; (2) after acidification with $\mathrm{HClO}_{4}$ to $\mathrm{pH} 0$.

additional band at $991 \mathrm{~nm}$ that increases with $\mathrm{pH}$ due to the increasing carbonate complexation. The band at $980.6 \mathrm{~nm}$ is characteristic of uncomplexed $\mathrm{NpO}_{2}{ }^{+}$. The band at $991 \mathrm{~nm}$ was established by Nitsche, et al..$^{33}$ It is typical for neptunyl(V) carbonate complexation.

To show that the band at $991 \mathrm{~nm}$ was indeed due to neptunyl(V) complexation by carbonate, we acidified the solutions to liberate the carbonate as carbon dioxide. Each of the solutions was acidified to $\mathrm{pH} \sim 0$ with $\mathrm{HClO}_{4}$ and observed for gas formation. All solutions, with the exception of the pH 6 oversaturation solution, gave off detectable amounts of $\mathrm{CO}_{2}$ gas. The spectra of the acidified cell was then immediately taken. The absorption band at $991 \mathrm{~nm}$ disappeared, and only the band at $980.6 \mathrm{~nm}$ from uncomplexed neptunium(V) remained. Through this procedure, we established that all solutions contained neptunyl(V) carbonate complex(es) with the exception of the pH 6 sample from oversaturation. The spectrum of this sample, before acidification, showed only the absorption band at $980.6 \mathrm{~nm}$, and upon addition of $\mathrm{HClO}_{4}$ showed no gas formation or change in the absorption spectrum. We determined the relative amounts of free neptunium and complexed neptunium (present as carbonate complex) from the difference between the total amount of neptunium in solution (determined by $\gamma$-spectroscopy) and the free $\mathrm{NpO}_{2}{ }^{+}$ determined from the $980.6 \mathrm{~nm}$ absorption band. The results of our neptunium speciation study are summarized in Table VII. It should be noted that we analyzed the $\mathrm{pH} 6$ undersaturation solution after the drop in $\mathrm{pH}$ occurred (as discussed in the solubility section). The spectra for this solution was taken several hundred days after we adjusted the $\mathrm{pH}$ to 6 . However, the relative 
amounts of complexed/uncomplexed neptunium was slightly higher than in the $\mathrm{pH} 6$ oversaturation solution where no complexation was evident.

Table VII. Comparison of extent of carbonate complexation for steady-state solutions of neptunium in UE-25p \#1 groundwater from over- and undersaturation at $60^{\circ} \mathrm{C}$.

\begin{tabular}{|c|c|c|c|c|}
\hline \multicolumn{5}{|c|}{ Neptunium Carbonate Complexation (\%) } \\
\hline \multirow{2}{*}{$\mathrm{pH}$} & \multicolumn{2}{|c|}{ Oversaturation } & \multicolumn{2}{c|}{ Undersaturation } \\
\cline { 2 - 5 } & $\mathrm{NpO}_{2}{ }^{+}$ & $\mathrm{NpO}_{2}\left(\mathrm{CO}_{3}\right)^{-}$ & $\mathrm{NpO}_{2}{ }^{+}$ & $\mathrm{NpO}_{2}\left(\mathrm{CO}_{3}\right)^{-}$ \\
\hline 6 & 100 & 0 & 76 & 24 \\
\hline 7 & 90 & 10 & 66 & 34 \\
\hline 8.5 & 0 & 100 & 0 & 100 \\
\hline
\end{tabular}

We used a non-linear, least-squares peak fitting routine (Spectra Calc, Galactic Industries Corporation, Salem, New Hampshire) to deconvolute the five absorption spectra that showed carbonate complexation in order to determine the complex stoichiometry. The results for the spectrum from the $\mathrm{pH} 7$ undersaturation solution, shown in Figure 9, indicate that the spectrum is composed of only two peaks: one at $980.6 \mathrm{~nm}$ for the uncomplexed $\mathrm{NpO}_{2}{ }^{+}$and a second one at $991 \mathrm{~nm}$ for the $\mathrm{NpO}_{2} \mathrm{CO}_{3}-$ complex. Higher complexes such as the $\mathrm{NpO}_{2}\left(\mathrm{CO}_{3}\right)_{2}{ }^{3-}$ complex, did not fit the spectrum. This was the case for all of the complexed spectra. The $\mathrm{pH} 8.5$ solutions, from both over- and undersaturation cells, fit only one species; that of $\mathrm{NpO}_{2} \mathrm{CO}_{3}$ - because all of the neptunium in solution was complexed. 


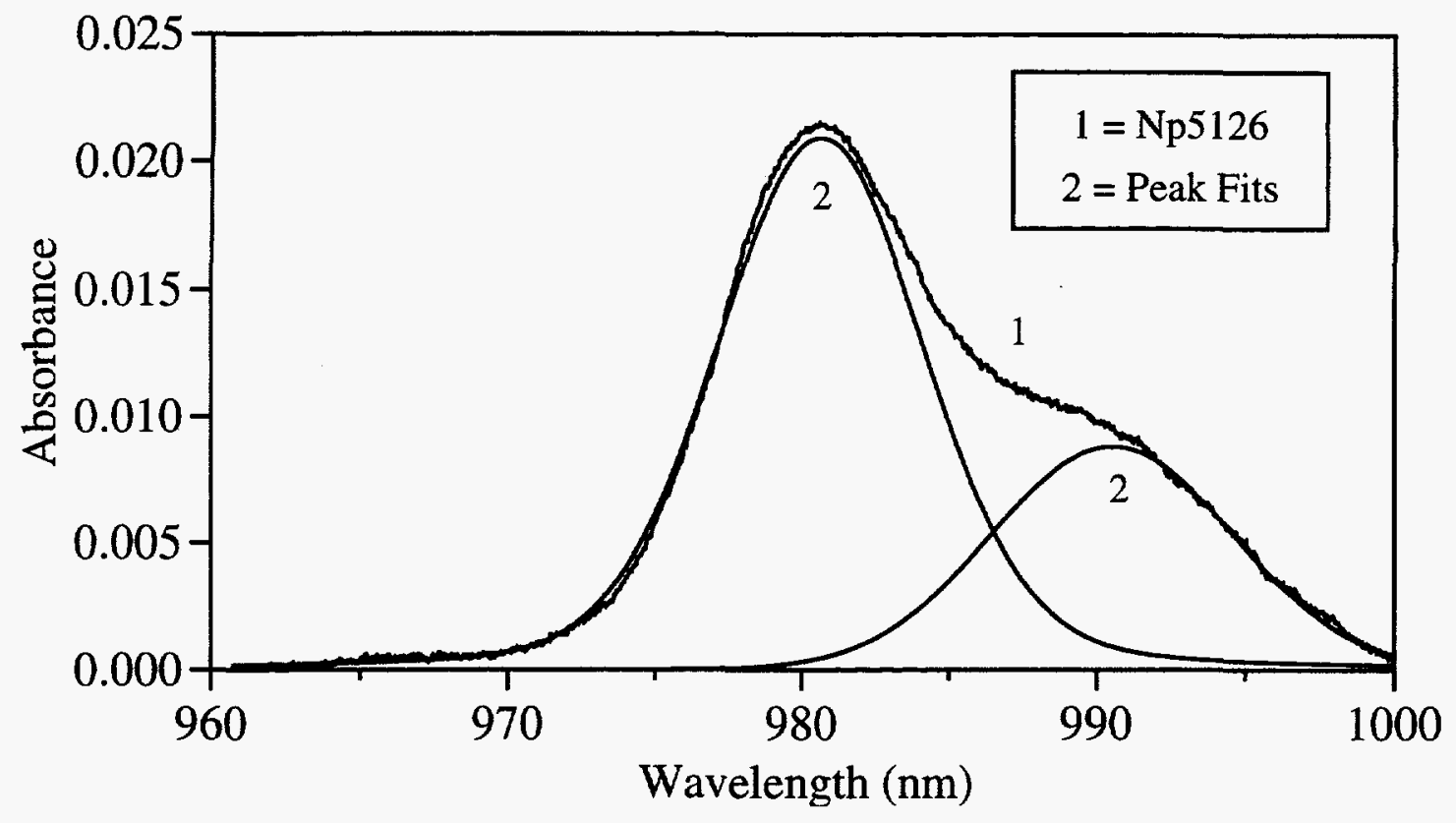

Figure 9. Deconvolution of the spectrum from the neptunium undersaturation experiment at $\mathrm{pH} 7$ and $60^{\circ} \mathrm{C}$ showing the two deconvoluted peaks at 980.6 and $991 \mathrm{~nm}$.

5.1.3. Identification of Solids. The precipitates formed in the neptunium solutions were collected by centrifugation, washed with a small amount of $\mathrm{CO}_{2}$-free water, and dried with a jet of argon.

When wet, all precipitates, from both the over- and undersaturation experiments, were a very faint green color; however, when completely dry, they all became white crystalline solids. X-ray powder diffraction patterns taken from precipitates produced distinct lines; crystal lattice dspacings and relative intensities are listed in Tables VIII, IX, and X.

All of the solids obtained from the three neptunium oversaturation experiments matched well with each other. Twelve of the 26 lines from the $\mathrm{pH} 6$ solid matched with the other two oversaturation solids to within $\pm 0.02 \AA$. Twelve of the 14 lines from the $\mathrm{pH} 7$ solid matched, and twelve of the 21 lines matched from the $\mathrm{pH} 8.5$ solid. The solids from the $\mathrm{pH} 6$ and $\mathrm{pH} 8.5$ oversaturation cells matched even better. Twenty of the 26 lines in the pH 6 solid matched with the pH 8.5 solid to within $\pm 0.02 \AA$, and 18 of 21 lines in the $\mathrm{pH} 8.5$ solid matched with the $\mathrm{pH} 6$ solid. The $\mathrm{pH} 7$ solid had relatively fewer "weak" and "trace" lines, probably as a result of its shorter exposure time. However, the strong and medium intensity lines matched well with the pH 6 and $\mathrm{pH} 8.5$ solids. The comparison of the three oversaturation solids is given in Table VIII.

As was indicated in a previous report on the UE-25p \#1 solids ${ }^{32}$, the comparison of the $60^{\circ} \mathrm{C}$ oversaturation solid patterns with patterns in the literature agreed to varying degrees. All of the solids obtained were similar to ternary sodium neptunium carbonate hydrates of different 
stoichiometry and/or water content. It should be noted that many of the corresponding solids described in the literature are metastable, difficult to reproduce, and show the extent to which line spacings vary. $34,35,36,37$

Four solids were obtained from the neptunium experiments from undersaturation: one from each of the $\mathrm{pH} 7$ and $\mathrm{pH} 8.5$ cells at the conclusion of these experiments, and two from the $\mathrm{pH} 6$ cell. The solids from the $\mathrm{pH} 6$ cell were removed at two separate times during the experiment: 1) at day 210 , when the solubility dropped an order of magnitude, and 2) at the end of the experiment after almost 400 days of equilibration time. Table $X$ lists the $d$-spacings and intensities for all of the final solids obtained in these experiments. Table IX lists the d-spacings and intensities for the solid removed at day 210 from the $\mathrm{pH} 6$ undersaturation cell.

The solid removed from the $\mathrm{pH} 6$ undersaturation cell, after the drop in solubility, gave a powder pattern with d-spacings that were very different from those of the starting solid from the oversaturation experiment (from either the $\mathrm{pH} 6$ or the $\mathrm{pH} 7$ cell). Table IX shows a comparison of the first solid removed from the $\mathrm{pH} 6$ cell with the solids obtained from the oversaturation experiments at $\mathrm{pH} 6$ and $\mathrm{pH} \mathrm{7.} \mathrm{The} \mathrm{first} \mathrm{undersaturation} \mathrm{solid} \mathrm{from} \mathrm{the} \mathrm{pH} 6$ cell contains nearly twice as many diffraction lines, very few of which match within $\pm 0.03 \AA$ of the oversaturation solids. The fact that the solubility dropped one order of magnitude, combined with the different powder pattern obtained, suggests that a different, more crystalline solid phase formed. The solid, most likely, has a more thermodynamically stable crystal lattice which lead to a lower solubility in the groundwater. Comparison of the powder pattern from this solid with patterns found in the literature are given in Tables XI and XII. The solid fit poorly with all of the references it was compared to. The best fit was obtained with the published patterns $\mathrm{NaNpO}_{2} \mathrm{CO}_{3} \bullet 3.5 \mathrm{H}_{2} \mathrm{O}$ and $\mathrm{NaNpO}_{2} \mathrm{CO}_{3} .{ }^{36}$ In the $\mathrm{pH} 6$ solid, 10 of the 48 lines matched the $\mathrm{NaNpO}_{2} \mathrm{CO}_{3} \cdot 3.5 \mathrm{H}_{2} \mathrm{O}$ solid to within $\pm 0.03 \AA$ and only 5 matched to within $\pm 0.01 \AA$. The match with the $\mathrm{NaNpO}_{2} \mathrm{CO}_{3}$ solid was slightly better; with 11 of the 48 lines matching to within $\pm 0.03 \AA$ and 7 of the 48 lines matching within $\pm 0.01 \AA$. At this time the solid remains unidentified, but based on the predominance of sodium in the groundwater accompanied by the high carbonate content, leads us to conclude that this solid is of the sodium neptunium(V) carbonate type.

The solid removed from the $\mathrm{pH} 6$ undersaturation cell after almost 400 days of equilibration time gave a different powder pattern than the solid removed at 200 days. The pattern of the solid removed from the cell at the end of the experiment is shown in Table XIII along with a comparison to $\mathrm{KNpO}_{2} \mathrm{CO}_{3}$ and $\mathrm{NaNpO}_{2} \mathrm{CO}_{3}$ reference patterns from the literature. The powder pattern of the pH 6 solid matched 11 out of 34 lines from the $\mathrm{KNpO}_{2} \mathrm{CO}_{3}$ to within $\pm 0.01 \AA$ and 14 out of 34 lines to within $\pm 0.03 \AA$. It matched 11 out of 34 lines from the $\mathrm{NaNpO}_{2} \mathrm{CO}_{3}$ 
literature reference to within $\pm 0.01 \AA$ and 18 out of 34 lines to within $\pm 0.03 \AA$. Again, due to the predominance of sodium in the UE-25p \#1 groundwater, it would appear that the solid formed was very similar to $\mathrm{NaNpO}_{2} \mathrm{CO}_{3}$.

The powder pattern from the $\mathrm{pH} 7$ undersaturation solid matched that of the literature reference pattern of $\mathrm{Na}_{0.6} \mathrm{NpO}_{2}\left(\mathrm{CO}_{3}\right)_{0.8} \cdot 2.5 \mathrm{H}_{2} \mathrm{O}^{34}$ relatively well. The comparison of the two solids is given in Table XIV. Twenty two out of 48 lines fit to within $\pm 0.01 \AA$, and 31 out of 48 lines fit to within $\pm 0.03 \AA$. It should be noted that the $x$-ray diffraction pattern for the $\mathrm{Na}_{0.6} \mathrm{NpO}_{2}\left(\mathrm{CO}_{3}\right)_{0.8}$ - $2.5 \mathrm{H}_{2} \mathrm{O}$ solid has much in common with hydrate forms of sodium monocarbonateneptunylate ${ }^{34} \mathrm{NaNpO}_{2} \mathrm{CO}_{3}$, and it is possible that we obtained a mixture of the $\mathrm{Na}_{0.6} \mathrm{NpO}_{2}\left(\mathrm{CO}_{3}\right)_{0.8} \cdot 2.5 \mathrm{H}_{2} \mathrm{O}$ and the $\mathrm{NaNpO}_{2} \mathrm{CO}_{3}$ solids. In light of the difficulties in justifying the stoichiometry of the $\mathrm{Na}_{0.6} \mathrm{NpO}_{2}\left(\mathrm{CO}_{3}\right)_{0.8} \cdot 2.5 \mathrm{H}_{2} \mathrm{O}$ solid, it is also possible that the solid obtained was simply $\mathrm{NaNpO}_{2} \mathrm{CO}_{3}$.

The powder pattern from the $\mathrm{pH} 8.5$ undersaturation solid matched that of the literature reference pattern of $\mathrm{Na}_{3} \mathrm{NpO}_{2}\left(\mathrm{CO}_{3}\right)_{2} \cdot \mathrm{nH}_{2} \mathrm{O}^{35}$ fairly well. A comparison of the two patterns is given in Table XV. Nine out of 30 lines fit to within $\pm 0.01 \AA$ and 19 out of 30 lines fit to within \pm 0.03 $\AA$. The fit with the solid of higher carbonate content is consistent with the increase in $\mathrm{pH}$ and carbonate available for complexation and solid formation in the cell. This is also consistent with the solubility decrease, as the higher $\mathrm{pH}$ increased the free carbonate in solution and precipitated more of the aqueous neptunium resulting in a lower neptunium solubility. This is simply the $\mathrm{pH}$ effect on the solubility of the carbonate containing solid in solution. Since there are such discrepancies in the line spacings for the various powder patterns of ternary sodium neptunium carbonates in the literature, we suggest that a detailed study of these solids be performed, so that differences can be clearly explained. We also suggest measuring the solubility of defined ternary neptunium carbonate solids as a function of solution $\mathrm{pH}$ in order to obtain the solubility products required for modeling calculations. 
Table VIII. X-ray powder diffraction patterns of neptunium solid phases from oversaturation in UE-25p \#1 groundwater at $60^{\circ} \mathrm{C}$ and $\mathrm{pH} 6,7$, and 8.5 .

\begin{tabular}{|c|c|c|c|c|c|}
\hline \multicolumn{2}{|c|}{$\begin{array}{c}\text { pH } 6 \\
\text { (oversat.) }\end{array}$} & \multicolumn{2}{|c|}{$\begin{array}{c}\text { pH } 7 \\
\text { (oversat.) }\end{array}$} & \multicolumn{2}{|c|}{$\begin{array}{c}\mathrm{pH} 8.5 \\
\text { (oversat.) }\end{array}$} \\
\hline$\underline{\mathrm{d}(\AA)}$ & $\underline{I}$ & $\underline{\mathrm{d}(\AA)}$ & $\underline{I}$ & $\underline{\mathrm{d}(\AA)}$ & $\underline{I}$ \\
\hline 9.41 & vS & 9.41 & s & 9.43 & $s$ \\
\hline 4.87 & $\mathrm{~m}$ & 4.88 & m- & 4.86 & w \\
\hline 4.70 & $\mathrm{~S}$ & 4.72 & s - & 4.70 & $\mathrm{~s}$ \\
\hline 4.34 & $\mathbf{S}$ & 4.33 & s - & 4.33 & $\mathrm{~s}$ \\
\hline 3.93 & s - & 3.95 & $\mathrm{~m}$ & 3.93 & s - \\
\hline 3.40 & $\mathrm{t}$ & 3.38 & $w$ & 3.38 & w \\
\hline 3.26 & $\mathrm{~m}$ & 3.24 & $w$ & 3.25 & $w+$ \\
\hline 3.20 & $t$ & & & & \\
\hline 3.15 & $\mathbf{w}$ & 3.14 & $\mathbf{t}$ & 3.15 & w \\
\hline 3.07 & $\mathbf{S}$ & 3.06 & m- & 3.06 & $\mathbf{S}$ \\
\hline 2.67 & $\mathrm{~m}$ & 2.67 & w - & 2.68 & $\mathbf{w}$ \\
\hline 2.55 & $\mathbf{w}$ & & & 2.54 & $t$ \\
\hline 2.43 & w & & & 2.44 & $t$ \\
\hline 2.36 & $\mathrm{~m}$ & 2.36 & $\mathrm{t}$ & 2.36 & w - \\
\hline 2.25 & $t$ & & & & \\
\hline 2.17 & $\mathrm{t}$ & 2.17 & $\mathrm{t}$ & 2.16 & $t$ \\
\hline 2.12 & $\mathrm{~m}$ & 2.12 & $\mathrm{t}$ & 2.12 & $\mathbf{w}$ \\
\hline 2.07 & $w$ & 2.07 & $t$ & 2.08 & $\mathbf{w}$ \\
\hline 1.97 & $\mathrm{t}$ & & & 1.97 & $\mathbf{t}$ \\
\hline 1.93 & $\mathbf{w}$ & & & 1.94 & $t$ \\
\hline 1.90 & $\mathbf{t}$ & & & 1.90 & $t$ \\
\hline 1.89 & $\mathbf{t}$ & & & 1.89 & $\mathrm{t}$ \\
\hline 1.76 & $w+$ & & & 1.76 & w \\
\hline 1.62 & $\mathrm{t}$ & & & & \\
\hline 1.60 & $\mathrm{t}$ & & & & \\
\hline 1.57 & $\mathrm{t}$ & & & & \\
\hline
\end{tabular}

(a) Relative intensities visually estimated: $v s=$ very strong, $\mathrm{s}=$ strong, $\mathrm{m}=$ medium, $w=$ weak, $t=$ trace. 
Table IX. X-ray powder diffraction pattern of neptunium solid phase from undersaturation in UE-25p \#1 groundwater at $60^{\circ} \mathrm{C}$ and $\mathrm{pH} 6$ removed after day 210 , compared with oversaturation solids from $\mathrm{pH}$ 6 and 7.

\begin{tabular}{|c|c|c|c|c|c|}
\hline \multicolumn{2}{|c|}{$\begin{array}{l}\text { pH } 6 \text { (1st ppt.) } \\
\text { (undersat.) }\end{array}$} & \multicolumn{2}{|c|}{$\begin{array}{c}\mathrm{pH} 6 \\
\text { (oversat.) }\end{array}$} & \multicolumn{2}{|c|}{$\begin{array}{c}\mathrm{pH} 7 \\
\text { (oversat.) } \\
\end{array}$} \\
\hline$d(\AA)$ & $\underline{I}$ & $\mathrm{~d}(\boldsymbol{\AA} \mathbf{\Omega})$ & 1 & $\Phi(\AA ̊)$ & I \\
\hline 9.85 & w & & & & \\
\hline & & 9.41 & vs & 9.41 & $\mathrm{~s}$ \\
\hline 7.48 & w & & & & \\
\hline 6.57 & $\mathbf{s}$ & & & & \\
\hline 5.11 & $t$ & & & & \\
\hline & & 4.87 & $\mathbf{m}$ & 4.88 & $\mathrm{~m}$ \\
\hline 4.80 & $t$ & 477 & s & 477 & \\
\hline 4.55 & $m$ & & & & \\
\hline & & 4.34 & $\mathbf{s}$ & 4.33 & s- \\
\hline 4.24 & $w+$ & & & & \\
\hline 4.06 & $\mathrm{~m}$ & 393 & 5 & 395 & $m$ \\
\hline 3.72 & $t$ & 3.73 & & 3.70 & iit \\
\hline 3.51 & $s$ & 3.40 & t & 3.38 & $w$ \\
\hline 3.34 & $t$ & & $m$ & & \\
\hline 3.21 & $\mathrm{~m}+$ & $\begin{array}{l}3.26 \\
3.20\end{array}$ & $\begin{array}{l}m \\
t\end{array}$ & 3.24 & $w$ \\
\hline 5.28 & & 3.15 & w & 3.14 & t \\
\hline & & 3.07 & $\mathrm{~s}$ & 3.06 & $\mathrm{~m}$ \\
\hline 3.00 & $t$ & & & & \\
\hline 2.96 & $\mathrm{t}$ & & & & \\
\hline 2.84 & $t$ & & & & \\
\hline 2.77 & $t$ & & & & \\
\hline 2.68 & $t$ & 2.67 & $\mathrm{~m}$ & 2.67 & w- \\
\hline 2.61 & $\mathrm{t}$ & & & & \\
\hline 2.55 & $\mathrm{~m}$ & 2.55 & $w$ & & \\
\hline 2.42 & $\mathrm{t}$ & 2.43 & $\mathbf{w}$ & & \\
\hline 2.40 & $\mathrm{t}$ & 2.36 & $\mathbf{m}$ & 2.36 & $t$ \\
\hline 2.31 & $t$ & & & & \\
\hline 2.26 & $\mathrm{t}$ & 2.25 & $t$ & & \\
\hline 2.20 & $\mathbf{w}$ & & & & \\
\hline 2.17 & w & 2.17 & $t$ & 2.17 & $t$ \\
\hline 2.10 & w & 2.12 & $\mathrm{~m}$ & 2.12 & $\mathbf{t}$ \\
\hline & & 2.07 & w & 2.07 & \\
\hline 1.99 & $s$ & 1.97 & $t$ & & \\
\hline 1.93 & $\mathrm{t}$ & 1.93 & w & & \\
\hline 1.90 & $w$ & 1.90 & $t$ & & \\
\hline & & 1.89 & $\mathrm{t}$ & & \\
\hline 1.85 & $\mathrm{t}$ & & & & \\
\hline 1.81 & $\mathrm{t}$ & & & & \\
\hline 1.80 & w- & & & & \\
\hline 1.75 & w & 1.76 & $w+$ & & \\
\hline 1.72 & w & & & & \\
\hline 1.66 & $t$ & 1.62 & $t$ & & \\
\hline & & 1.60 & $t$ & & \\
\hline 1.56 & t & 1.57 & $t$ & & \\
\hline 1.52 & w- & & & & \\
\hline 1.49 & $t$ & & & & \\
\hline 1.47 & $t$ & & & & \\
\hline 1.41 & $t$ & & & & \\
\hline 1.39 & $t$ & & & & \\
\hline 1.34 & t & & & & \\
\hline 1.31 & t & & & & \\
\hline $\begin{array}{l}1.27 \\
24\end{array}$ & t & & & & \\
\hline $\begin{array}{l}1.24 \\
1.21\end{array}$ & $\begin{array}{l}\text { W- } \\
t^{-1}\end{array}$ & & & & \\
\hline 1.19 & $t$ & & & & \\
\hline 1.15 & $t$ & & & & \\
\hline
\end{tabular}

(a) Relative intensities visually estimated: $\mathrm{vs}=$ very strong, $\mathrm{s}=$ strong, $\mathrm{m}=$ medium, $\mathrm{w}=$ weak, $\mathrm{t}=$ trace. 
Table X. X-ray powder diffraction patterns of neptunium solid phases from undersaturation in UE-25p \#1 groundwater at $60^{\circ} \mathrm{C}$ and $\mathrm{pH} \mathrm{6,7}$, and 8.5 (solids removed at the conclusion of all experiments).

\begin{tabular}{|c|c|c|c|c|c|}
\hline \multicolumn{2}{|c|}{$\begin{array}{c}\text { pH } 6 \\
\text { (undersat.) }\end{array}$} & \multicolumn{2}{|c|}{$\begin{array}{c}\text { pH } 7 \\
\text { (undersat.) }\end{array}$} & \multicolumn{2}{|c|}{$\begin{array}{c}\text { pH } 8.5 \\
\text { (undersat.) }\end{array}$} \\
\hline $\mathrm{d}(\AA \AA)$ & \multirow[t]{2}{*}{ I } & $\mathrm{d}(\AA)$ & I & $\mathrm{d}(\hat{A})$ & I \\
\hline \multirow[t]{3}{*}{9.31} & & 9.43 & $\mathrm{~s}$ & & \\
\hline & \multirow{2}{*}{$s$} & & & 8.63 & $w$ \\
\hline & & & & 6.92 & t \\
\hline 6.55 & $\mathbf{w}$ & 6.13 & $\mathrm{t}$ & 0.30 & 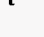 \\
\hline \multirow{2}{*}{$\begin{array}{l}5.08 \\
4.87\end{array}$} & $\mathbf{m}$ & & & \multirow[t]{3}{*}{5.09} & \multirow[t]{2}{*}{$\mathrm{mt}$} \\
\hline & $w$ & 4.89 & $\mathbf{w}$ & & \\
\hline 4.70 & $\mathrm{~m}$ & 4.70 & s- & & \multirow[b]{2}{*}{ s- } \\
\hline \multirow{2}{*}{4.39} & \multirow[t]{2}{*}{$w$} & & & \multirow[t]{2}{*}{4.43} & \\
\hline & & $\begin{array}{l}4.34 \\
4.21\end{array}$ & s- & & \\
\hline \multirow{5}{*}{$\begin{array}{l}4.07 \\
3.99\end{array}$} & $\mathbf{s}$ & 4.05 & $t$ & 4.06 & $s$ \\
\hline & $t$ & & & & \\
\hline & & 3.94 & $\mathrm{~m}+$ & & \\
\hline & & 3.57 & $t$ & & \\
\hline & & 3.40 & $w+$ & & \\
\hline 3.33 & $m$ & & & 3.34 & m \\
\hline 3.23 & $\mathrm{~m}$ & 3.25 & $\mathbf{m}$ & 3.25 & $t$ \\
\hline & & 3.19 & $\mathrm{~m}$ & & \\
\hline 3.14 & w- & 3.14 & $\mathbf{m}$ & & \\
\hline 3.05 & $t$ & 3.07 & $m+$ & 3.10 & $t$ \\
\hline & & 2.88 & w- & $\begin{array}{l}2.93 \\
2.82\end{array}$ & $\begin{array}{l}w \\
m\end{array}$ \\
\hline 2.68 & $\mathrm{~m}$ & 2.68 & $\mathbf{m}$ & 2.68 & $w$ \\
\hline 2.55 & $\mathrm{~m}+$ & 2.55 & $w$ & 2.55 & s- \\
\hline 2.44 & $t$ & 2.43 & w- & & \\
\hline 2.36 & $i$ & 2.37 & $\mathbf{w}$ & & \\
\hline 2.28 & $w+$ & 2.26 & w. & 2.27 & $w$ \\
\hline 2.21 & 1 & & & 2.21 & $w$ \\
\hline 2.16 & $\mathrm{~m}$ & 2.18 & $\mathbf{m}$ & 2.16 & $\mathrm{~m}$ \\
\hline & & $\begin{array}{l}2.13 \\
2.08\end{array}$ & $\begin{array}{l}\mathrm{m}+ \\
\mathrm{m}\end{array}$ & & \\
\hline 2.03 & $t$ & & & 2.03 & $\mathbf{t}$ \\
\hline 1.99 & $s$ & 2.00 & $m+$ & 1.99 & s \\
\hline & & 1.94 & $\mathrm{~m}$ & & \\
\hline & & 1.91 & w- & & \\
\hline & & 1.88 & $t$ & & \\
\hline 1.85 & $w$ & 1.86 & $\mathrm{t}$ & 1.85 & $w$ \\
\hline 1.80 & $\mathbf{w}$ & 1.83 & $t$ & 1.80 & $\mathbf{w}$ \\
\hline & & 1.76 & w- & & \\
\hline 1.73 & $w+$ & 1.73 & w- & 1.73 & $w$ \\
\hline 1.65 & $w+$ & 1.67 & $t$ & 1.65 & $w$ \\
\hline 1.62 & $t$ & 1.63 & $w-$ & & \\
\hline 1.59 & i & 1.60 & w- & 1.59 & $t$ \\
\hline & & 1.58 & w- & & \\
\hline & & 1.52 & $t$ & & \\
\hline 1.50 & $w$ & 1.50 & 1 & 1.50 & $t$ \\
\hline 1.48 & $\mathrm{t}$ & 1.48 & t & 1.47 & $t$ \\
\hline & & 1.45 & t & & \\
\hline 1.42 & $t$ & 1.41 & w- & 1.41 & $t$ \\
\hline & & 1.39 & $t$ & & \\
\hline & & 1.37 & t & & \\
\hline 1.30 & t & 1.30 & $w-$ & 1.29 & $t$ \\
\hline 1.28 & $\mathrm{t}$ & & & 1.28 & $w$ \\
\hline 1.25 & $w+$ & 1.25 & w- & & \\
\hline & & 1.24 & $w-$ & 1.24 & w- \\
\hline 1.22 & $t$ & 1.22 & $\mathrm{t}$ & 1.22 & $t$ \\
\hline & & 1.14 & $t$ & & \\
\hline
\end{tabular}

(a) Relative intensities visually estimated: $v s=$ very strong, $\mathrm{s}=$ strong, $\mathrm{m}=$ medium, $\mathrm{w}=$ weak, $\mathrm{t}=$ trace. 
Table XI. X-ray powder diffraction pattern of neptunium solid phase from undersaturation in UE-25p \#1 groundwater at $60^{\circ} \mathrm{C}$ and $\mathrm{pH} 6$ removed after day 210 , compared with the pattern of $\mathrm{NaNpO}_{2} \mathrm{CO}_{3} \cdot 3.5 \mathrm{H}_{2} \mathrm{O}^{36}$

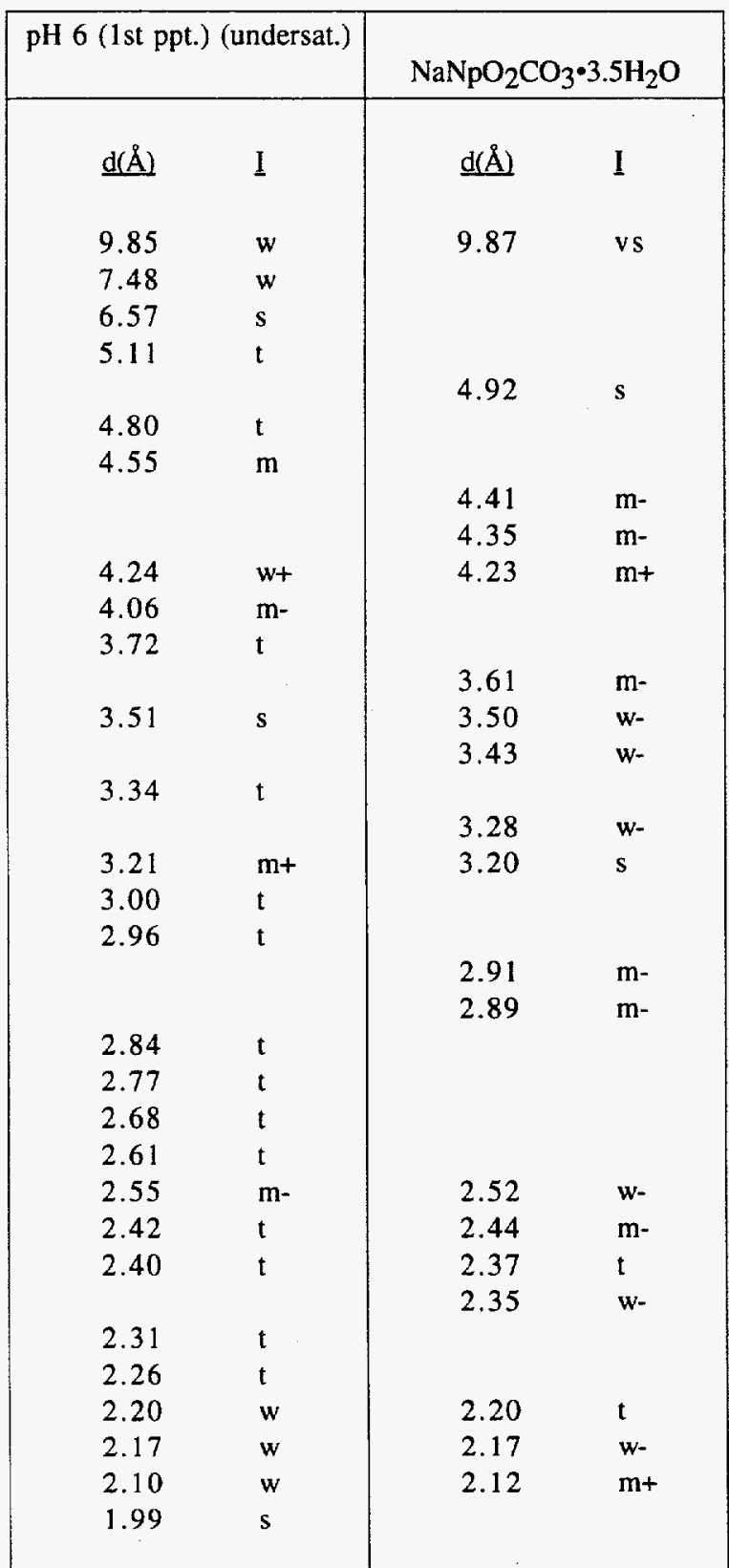

(a) Relative intensities visually estimated: vs $=$ very strong, $\mathrm{s}=$ strong, $\mathrm{m}=$ medium, $\mathrm{w}=$ weak, $t=$ trace

(b) The $\mathrm{pH} 6$ pattern has 21 additional lines ( $w$ and $t$ ), not listed here, ranging from $1.93 \AA$ to $122 \mathrm{~A}$. 
Table XII. X-ray powder diffraction pattern of neptunium solid phase from undersaturation in UE-25p \#1 groundwater at $60^{\circ} \mathrm{C}$ and $\mathrm{pH} 6$ removed after day 210 , compared with the pattern of $\mathrm{NaNpO}_{2} \mathrm{CO}_{3} .36$

\begin{tabular}{|cc|cc|}
\hline $\begin{array}{c}\text { pH } 6 \text { (Ist ppt.) } \\
\text { (undersat.) }\end{array}$ & \multicolumn{2}{|c|}{$\mathrm{NaNpO}_{2} \mathrm{CO}_{3}$} \\
\hline $\mathrm{d}(\AA)$ & $\mathrm{I}$ & $\underline{\mathrm{d}(\AA)}$ & $\mathrm{I}$ \\
& & & \\
9.85 & $\mathrm{w}$ & & \\
7.48 & $\mathrm{w}$ & & \\
6.57 & $\mathrm{~s}$ & & \\
& & 5.35 & $\mathrm{vs}$ \\
5.11 & $\mathrm{t}$ & & \\
4.80 & $\mathrm{t}$ & & \\
4.55 & $\mathrm{~m}$ & & \\
& & 4.44 & $\mathrm{vs}$ \\
4.24 & $\mathrm{w}+$ & & \\
4.06 & $\mathrm{~m}-$ & 4.05 & $\mathrm{vs}$ \\
3.72 & $\mathrm{t}$ & & \\
3.51 & $\mathrm{~s}$ & & \\
3.34 & $\mathrm{t}$ & & \\
& & 3.25 & $\mathrm{vs}$ \\
3.21 & $\mathrm{~m}+$ & & \\
3.00 & $\mathrm{t}$ & & \\
2.96 & $\mathrm{t}$ & & \\
2.84 & $\mathrm{t}$ & 2.87 & $\mathrm{w}$ \\
2.77 & $\mathrm{t}$ & 2.77 & $\mathrm{vs}$ \\
2.68 & $\mathrm{t}$ & 2.67 & $\mathrm{~m}+$ \\
2.61 & $\mathrm{t}$ & & \\
2.55 & $\mathrm{~m}-$ & & \\
2.42 & $\mathrm{t}$ & 2.43 & $\mathrm{~m}+$ \\
2.40 & $\mathrm{t}$ & & \\
2.31 & $\mathrm{t}$ & & \\
2.26 & $\mathrm{t}$ & & \\
2.20 & $\mathrm{w}$ & 2.21 & $\mathrm{w}-$ \\
2.17 & $\mathrm{w}$ & 2.18 & $\mathrm{~m}+$ \\
2.10 & $\mathrm{w}$ & 2.08 & $\mathrm{vs}$ \\
& & 2.06 & $\mathrm{w}-$ \\
1.99 & $\mathrm{~s}$ & 2.01 & $\mathrm{w}$ \\
1.93 & $\mathrm{t}$ & 1.96 & $\mathrm{vs}$ \\
& & & \\
\hline
\end{tabular}

(a) Relative intensities visually estimated: $\mathrm{vs}=$ very strong, $\mathrm{s}=$ strong, $\mathrm{m}=$ medium, $\mathrm{w}=$ weak, $\mathrm{t}=$ trace

(b) The $\mathrm{pH} 6$ pattern has 20 additional lines ( $\mathrm{w}$ and $\mathrm{t}$ ), not listed here, ranging from $1.90 \AA$ to $1.22 \AA$. 
Table XIII. X-ray powder diffraction pattern of neptunium solid phase from undersaturation in UE-25p \#1 groundwater at $60^{\circ} \mathrm{C}$ and $\mathrm{pH} 6$ removed at day 410 compared with the patterns of $\mathrm{NaNpO}_{2} \mathrm{CO}_{3}$ and $\mathrm{KNpO}_{2} \mathrm{CO}_{3}$.

\begin{tabular}{|c|c|c|c|c|c|}
\hline \multicolumn{2}{|c|}{ pH 6 (2nd ppt.) (undersat.) } & \multicolumn{2}{|c|}{$\mathrm{NaNpO}_{2} \mathrm{CO}_{3}$} & \multicolumn{2}{|c|}{$\mathrm{KNpO}_{2} \mathrm{CO}_{3}$} \\
\hline$\underline{\mathrm{d}(\AA)}$ & I & $\underline{\mathrm{d}(\AA \AA)}$ & $\underline{I}$ & $\underline{\mathrm{d}(\AA)}$ & $\underline{I}$ \\
\hline 9.31 & $\mathbf{s}$ & & & & \\
\hline 6.55 & $w$ & & & & \\
\hline & & 5.35 & vs & & \\
\hline 5.08 & $\mathrm{~m}$ & & & 5.01 & $s$ \\
\hline 4.87 & $w$ & & & & \\
\hline 4.70 & $\mathrm{~m}$ & & & & \\
\hline 4.39 & $w$ & 4.44 & vs & 4.44 & $\mathrm{~m}$ \\
\hline 4.07 & $s$ & 4.05 & v s & 4.06 & vs \\
\hline 3.99 & $t$ & & & & \\
\hline 3.33 & $\mathrm{~m}$ & & & 3.31 & $\mathbf{s}$ \\
\hline 3.23 & m- & 3.25 & vs & & \\
\hline 3.14 & w- & & & & \\
\hline 3.05 & $t$ & & & & \\
\hline & & 2.87 & $w$ & & \\
\hline & & 2.77 & vs & & \\
\hline 2.68 & m- & 2.67 & $m+$ & 2.66 & $\mathrm{~m}$ \\
\hline 2.55 & $m+$ & & & 2.56 & $s$ \\
\hline & & & & 2.49 & $\mathrm{~m}$ \\
\hline 2.44 & $t$ & 2.43 & $\mathrm{~m}+$ & & \\
\hline 2.36 & $\mathrm{t}$ & & & & \\
\hline 2.28 & $w+$ & & & 2.28 & $\mathbf{m}$ \\
\hline 2.21 & $\mathrm{t}$ & 2.21 & w- & 2.22 & $w$ \\
\hline 2.16 & m- & 2.18 & $\mathrm{~m}+$ & 2.16 & $s$ \\
\hline & & 2.08 & vs & & \\
\hline & & 2.06 & w- & & \\
\hline 2.03 & $t$ & 2.01 & $w$ & 2.02 & $\mathrm{~m}$ \\
\hline 1.99 & $\mathrm{~s}$ & 1.96 & vs & & \\
\hline & & 1.91 & $w$ & & \\
\hline 1.85 & $w$ & & & 1.85 & w+ \\
\hline & & & & 1.82 & wt \\
\hline 1.80 & $w$ & & & 1.79 & $\mathrm{~m}$ \\
\hline 1.73 & $w+$ & & & & \\
\hline 1.65 & $w+$ & & & 1.65 & $\mathrm{~m}+$ \\
\hline 1.62 & $t$ & & & & \\
\hline 1.59 & $\mathrm{t}$ & & & 1.59 & $w$ \\
\hline & & & & 1.55 & $t$ \\
\hline 1.50 & $w$ & & & 1.50 & w \\
\hline 1.48 & $t$ & & & 1.48 & w \\
\hline
\end{tabular}

(a) Relative intensities visually estimated: $\mathrm{vs}=$ very strong, $\mathrm{s}=$ strong, $\mathrm{m}=$ medium, $\mathrm{w}=$ weak, $\mathrm{t}=$ trace.

(b) The pH 6 pattern has 5 additional lines ( $w$ and $t$ ), not listed here, ranging from $1.42 \AA$ to $1.22 \AA$. 
Table XIV. X-ray powder diffraction pattern of neptunium solid phase from undersaturation in UE-25p \#1 groundwater at $60^{\circ} \mathrm{C}$ and $\mathrm{pH} 7$ compared with the pattern of $\mathrm{Na}_{0.6} \mathrm{NpO}_{2}\left(\mathrm{CO}_{3}\right)_{0.8} \cdot 2.5 \mathrm{H}_{2} \mathrm{O}$.

\begin{tabular}{|c|c|c|c|}
\hline \multicolumn{2}{|c|}{$\begin{array}{c}\mathrm{pH} \mathrm{7} \\
\text { (undersat.) }\end{array}$} & \multicolumn{2}{|c|}{$\begin{array}{c}\mathrm{Na}_{0.6} \mathrm{NpO}_{2}\left(\mathrm{CO}_{3}\right)_{0.8} \\
\cdot 2.5 \mathrm{H}_{2} \mathrm{O} \\
\end{array}$} \\
\hline \multirow[t]{3}{*}{$\underline{\mathrm{d}(\AA)}$} & $\underline{1}^{\mathrm{a}}$ & $\underline{\mathrm{d}(\AA)}$ & $\underline{\mathbf{I}}^{\mathrm{a}}$ \\
\hline & & 13.64 & $\mathbf{t}$ \\
\hline & & 9.96 & s- \\
\hline 9.43 & s & & \\
\hline \multirow[t]{2}{*}{6.50} & $t$ & & \\
\hline & & 6.22 & $w$ \\
\hline \multirow[t]{2}{*}{6.13} & $\mathrm{t}$ & & \\
\hline & & 4.96 & s- \\
\hline 4.89 & w & 4.82 & w \\
\hline 4.70 & s- & & \\
\hline 4.34 & s- & 4.33 & vs \\
\hline 4.21 & $\mathrm{t}$ & & \\
\hline 4.05 & $\mathrm{t}$ & & \\
\hline \multirow[t]{2}{*}{3.94} & $\mathrm{~m}+$ & 3.97 & $\mathrm{~s}$ \\
\hline & & 3.73 & $\mathrm{t}$ \\
\hline \multirow[t]{3}{*}{3.57} & $\mathrm{t}$ & & \\
\hline & & 3.44 & $\mathrm{t}$ \\
\hline & & 3.30 & $\mathrm{t}$ \\
\hline 3.40 & $w+$ & & \\
\hline 3.25 & $\mathrm{~m}$ & 3.22 & s- \\
\hline 3.19 & m- & & \\
\hline 3.14 & $\mathrm{~m}-$ & & \\
\hline 3.07 & $\mathrm{~m}+$ & 3.06 & m- \\
\hline \multirow[t]{3}{*}{2.88} & w- & 2.89 & $\mathrm{t}$ \\
\hline & & 2.80 & w- \\
\hline & & 2.77 & w- \\
\hline \multirow[t]{2}{*}{2.68} & $\mathrm{~m}-$ & 2.70 & $\mathrm{~m}+$ \\
\hline & & 2.62 & w+ \\
\hline 2.55 & $w$ & & \\
\hline 2.43 & w- & 2.47 & $w$ \\
\hline \multirow[t]{3}{*}{2.37} & $w$ & 2.40 & $w+$ \\
\hline & & 2.34 & $t$ \\
\hline & & 2.30 & $\mathrm{t}$ \\
\hline 2.26 & w- & & \\
\hline 2.18 & $\mathrm{~m}$ & 2.16 & $\mathrm{~m}-$ \\
\hline 2.13 & $\mathrm{~m}+$ & 2.11 & $w$ \\
\hline 2.08 & $\mathrm{~m}$ & 2.06 & $\mathrm{~m}$ \\
\hline 2.00 & $\mathrm{~m}+$ & 1.98 & w- \\
\hline
\end{tabular}

\begin{tabular}{|c|c|c|c|}
\hline \multicolumn{2}{|c|}{$\begin{array}{c}\mathrm{pH} 7 \\
\text { (undersat.) }\end{array}$} & \multicolumn{2}{|c|}{$\begin{array}{c}\mathrm{Na}_{0.6} \mathrm{NpO}_{2}\left(\mathrm{CO}_{3}\right)_{0.8} \\
\cdot 2.5 \mathrm{H}_{2} \mathrm{O} \\
\end{array}$} \\
\hline \multirow[t]{2}{*}{$\underline{\mathrm{d}(\AA \AA)}$} & \multirow[t]{2}{*}{$\underline{1}^{\mathrm{a}}$} & $\underline{\mathrm{d}(\AA)}$ & $\underline{\mathbf{I}}^{\mathbf{a}}$ \\
\hline & & 1.96 & w- \\
\hline 1.94 & m- & 1.94 & $t$ \\
\hline 1.91 & w- & & \\
\hline 1.88 & $\mathrm{t}$ & & \\
\hline 1.86 & $\mathrm{t}$ & & \\
\hline \multirow[t]{2}{*}{1.83} & \multirow[t]{2}{*}{$\mathrm{t}$} & 1.83 & w- \\
\hline & & 1.80 & $\mathrm{t}$ \\
\hline 1.76 & w- & 1.77 & w \\
\hline 1.73 & w- & 1.72 & $\mathrm{t}$ \\
\hline 1.67 & $\mathrm{t}$ & 1.70 & $w$ \\
\hline 1.63 & w- & 1.63 & $t$ \\
\hline 1.60 & w- & 1.61 & w- \\
\hline 1.58 & w- & 1.58 & $\mathrm{t}$ \\
\hline 1.52 & $\mathrm{t}$ & 1.53 & w- \\
\hline 1.50 & $\mathrm{t}$ & 1.50 & $\mathrm{t}$ \\
\hline \multirow[t]{2}{*}{1.48} & \multirow[t]{2}{*}{$\mathrm{t}$} & 1.49 & $t$ \\
\hline & & 1.47 & $t$ \\
\hline \multirow[t]{2}{*}{1.45} & \multirow[t]{2}{*}{$t$} & 1.44 & $w$ \\
\hline & & 1.43 & $\mathrm{t}$ \\
\hline 1.41 & w- & 1.40 & $t$ \\
\hline 1.39 & $\mathrm{t}$ & 1.38 & $t$ \\
\hline \multirow[t]{3}{*}{1.37} & \multirow[t]{3}{*}{$t$} & 1.37 & $t$ \\
\hline & & 1.35 & $\mathbf{t}$ \\
\hline & & 1.33 & $\mathbf{t}$ \\
\hline \multirow[t]{2}{*}{1.30} & \multirow[t]{2}{*}{ w- } & 1.29 & $\mathbf{t}$ \\
\hline & & 1.28 & $t$ \\
\hline 1.25 & w- & 1.25 & $\mathbf{t}$ \\
\hline 1.24 & w- & 1.24 & $\mathrm{t}$ \\
\hline \multirow[t]{4}{*}{1.22} & \multirow[t]{4}{*}{$t$} & 1.23 & $\mathrm{t}$ \\
\hline & & 1.21 & $t$ \\
\hline & & 1.20 & $\mathrm{t}$ \\
\hline & & 1.16 & $t$ \\
\hline \multirow[t]{3}{*}{1.14} & \multirow[t]{3}{*}{$\mathrm{t}$} & 1.15 & $\mathrm{t}$ \\
\hline & & 1.13 & $t$ \\
\hline & & 1.11 & $\mathrm{t}$ \\
\hline
\end{tabular}

(a) Relative intensities visually estimated: $v s=$ very strong, $s=$ strong, $m=$ medium, $w=$ weak, $t=$ trace 
Table XV. X-ray powder diffraction pattern of neptunium solid phase from undersaturation in UE$25 \mathrm{p} \# 1$ groundwater at $60^{\circ} \mathrm{C}$ and $\mathrm{pH} 8.5$ compared with the pattern of $\mathrm{Na}_{3} \mathrm{NpO}_{2}\left(\mathrm{CO}_{3}\right)_{2} \bullet \mathrm{H}_{2} \mathrm{O}$.

\begin{tabular}{|c|c|c|c|}
\hline \multicolumn{2}{|c|}{$\begin{array}{c}\mathrm{pH} 8.5 \\
\text { (undersat.) }\end{array}$} & \multicolumn{2}{|c|}{$\mathrm{Na}_{3} \mathrm{NpO}_{2}\left(\mathrm{CO}_{3}\right)_{2} \bullet \mathrm{H}_{2} \mathrm{O}$} \\
\hline$\underline{\mathrm{d}(\AA)}$ & $\underline{I}^{\mathrm{a}}$ & $\underline{\mathrm{d}(\AA)}$ & $\underline{I}^{\mathrm{a}}$ \\
\hline 8.63 & $w$ & & \\
\hline 6.92 & $t$ & & \\
\hline \multirow[t]{3}{*}{6.58} & $\mathrm{t}$ & & \\
\hline & & 6.07 & $w$ \\
\hline & & 5.75 & $w+$ \\
\hline 5.09 & $m+$ & & \\
\hline \multirow[t]{2}{*}{4.43} & S- & 4.39 & vs \\
\hline & & 4.29 & w- \\
\hline \multirow[t]{2}{*}{4.06} & $\mathbf{s}$ & & \\
\hline & & 4.00 & $w+$ \\
\hline 3.34 & $\mathrm{~m}$ & & \\
\hline 3.25 & $t$ & & \\
\hline \multirow[t]{2}{*}{3.10} & $t$ & 3.11 & w- \\
\hline & & 2.99 & w- \\
\hline 2.93 & $w$ & 2.91 & w- \\
\hline 2.82 & m- & 2.80 & w- \\
\hline 2.68 & $w$ & 2.71 & $t$ \\
\hline \multirow[t]{2}{*}{2.55} & s- & 2.53 & $\mathrm{~m}$ \\
\hline & & 2.34 & $t$ \\
\hline 2.27 & $\mathbf{w}$ & & \\
\hline 2.21 & $w$ & 2.19 & m- \\
\hline \multirow{2}{*}{2.16} & $\mathrm{~m}$ & 2.14 & $\mathrm{t}$ \\
\hline & & 2.10 & $t$ \\
\hline 2.03 & $t$ & & \\
\hline \multirow[t]{4}{*}{1.99} & s & 2.00 & w- \\
\hline & & 1.97 & w- \\
\hline & & 1.94 & w- \\
\hline & & 1.90 & w- \\
\hline 1.85 & $w$ & 1.84 & $\mathbf{t}$ \\
\hline 1.80 & w & 1.80 & $\mathbf{t}$ \\
\hline \multirow[t]{2}{*}{1.73} & $\mathbf{w}$ & 1.74 & $t$ \\
\hline & & 1.70 & $t$ \\
\hline 1.65 & $w$ & 1.67 & $\mathbf{t}$ \\
\hline \multirow[t]{4}{*}{1.59} & $t$ & 1.60 & $t$ \\
\hline & & 1.57 & $\mathbf{t}$ \\
\hline & & 1.54 & $t$ \\
\hline & & 1.51 & $t$ \\
\hline 1.50 & $t$ & 1.50 & $t$ \\
\hline 1.47 & $t$ & 1.46 & w- \\
\hline \multirow[t]{2}{*}{1.41} & $t$ & 1,43 & $t$ \\
\hline & & 1.38 & $\mathbf{t}$ \\
\hline 1.29 & $t$ & 1.28 & t \\
\hline 1.28 & $\mathbf{w}$ & 1.27 & t \\
\hline 1.24 & w - & & \\
\hline 1.22 & I & & \\
\hline
\end{tabular}

(a) Relative intensities visually estimated: vs = very strong, $s$ $=$ strong, $\mathrm{m}=$ medium, $\mathrm{w}=$ weak, $\mathrm{t}=$ trace. 
5.2. Plutonium. 5.2.1. Solubility. Results of the plutonium solubility studies are shown in Figure 10. The plutonium was initially introduced as $\mathrm{Pu}^{4+}$ into the UE-25p \#1 groundwater. The steadystate concentrations and the solutions' Eh values are given in Table XVI. Concentration profiles as a function of time and $\mathrm{pH}$ for over- and undersaturation experiments at $60^{\circ} \mathrm{C}$ are shown in Figure 11. The individual measurements are listed in Appendix B. Results from plutonium filtration experiments at $60^{\circ} \mathrm{C}$ have been given elsewhere..$^{32}$ Methods used for the filtration experiments are described in Section 4.5. We could not find any volume effect for the plutonium, so we used 500 $\mu \mathrm{L}$ of solution as presaturation volume for routine separations.

\section{Plutonium(IV) Solubility Experiments from Over- and Undersaturation in UE-25p\#1 Water at $60^{\circ} \mathrm{C}$}

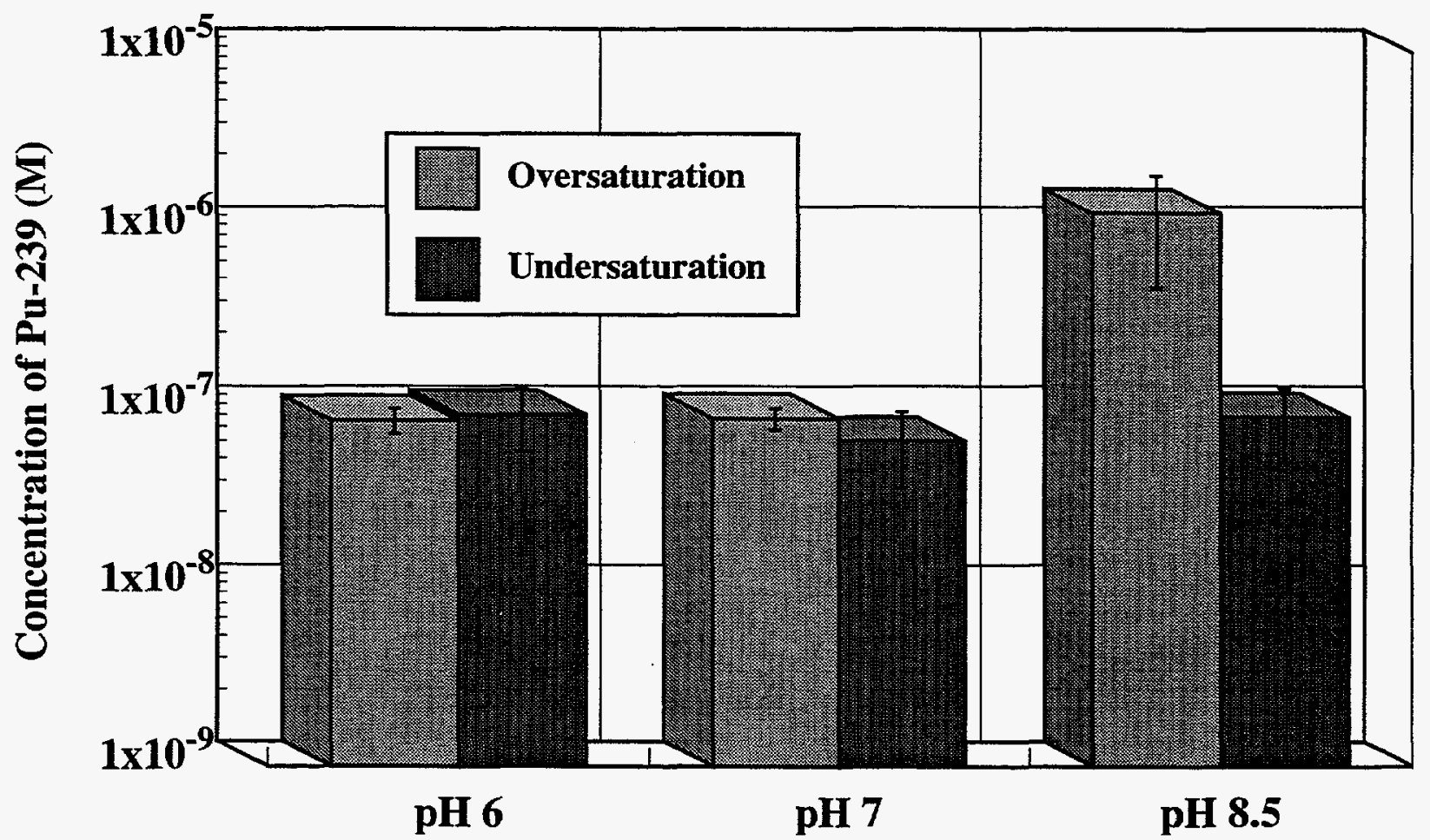

Figure 10. Results of the plutonium solubility experiments from over- and undersaturation in $\mathrm{UE}-25 \mathrm{p} \# 1$ groundwater at $60^{\circ} \mathrm{C}$ as a function of $\mathrm{pH}$. 
Table XVI. Comparison of steady-state solution concentrations and Eh for plutonium from over- and undersaturation in UE-25p $\# 1$ water at $60^{\circ} \mathrm{C}$.

\begin{tabular}{|c|c|c|c|c|}
\hline \multirow{2}{*}{$\mathrm{pH}$} & \multicolumn{4}{|c|}{ Plutonium(IV) } \\
\cline { 2 - 5 } & \multicolumn{3}{|c|}{ Concentration $(\mathrm{M})$} & \multicolumn{2}{c|}{ Eh (mV vs. NHE) } \\
\cline { 2 - 5 } & Oversaturation & Undersaturation & Oversaturation & Undersaturation \\
\hline 6 & $(8.8 \pm 1.4) \times 10^{-8}$ & $(9.5 \pm 3.6) \times 10^{-8}$ & $(326 \pm 15)$ & $(312 \pm 15)$ \\
\hline 7 & $(9.1 \pm 1.2) \times 10^{-8}$ & $(6.8 \pm 3.1) \times 10^{-8}$ & $(334 \pm 15)$ & $(313 \pm 15)$ \\
\hline 8.5 & $(1.3 \pm 0.8) \times 10^{-6}$ & $(9.2 \pm 4.0) \times 10^{-8}$ & $(231 \pm 15)$ & $(218 \pm 15)$ \\
\hline
\end{tabular}

In summary, plutonium steady-state concentrations from the over- and undersaturation experiments at $\mathrm{pH} 6$ and 7 agree very well. There was no change in the steady-state concentrations. The concentration at $\mathrm{pH} 8.5$ decreased by one order of magnitude. It appears that a new, more crystalline solid has formed, different from that from the oversaturation experiment. All of the undersaturation steady-state concentrations at the three $\mathrm{pH}$ 's agree within the error of the measurements. 


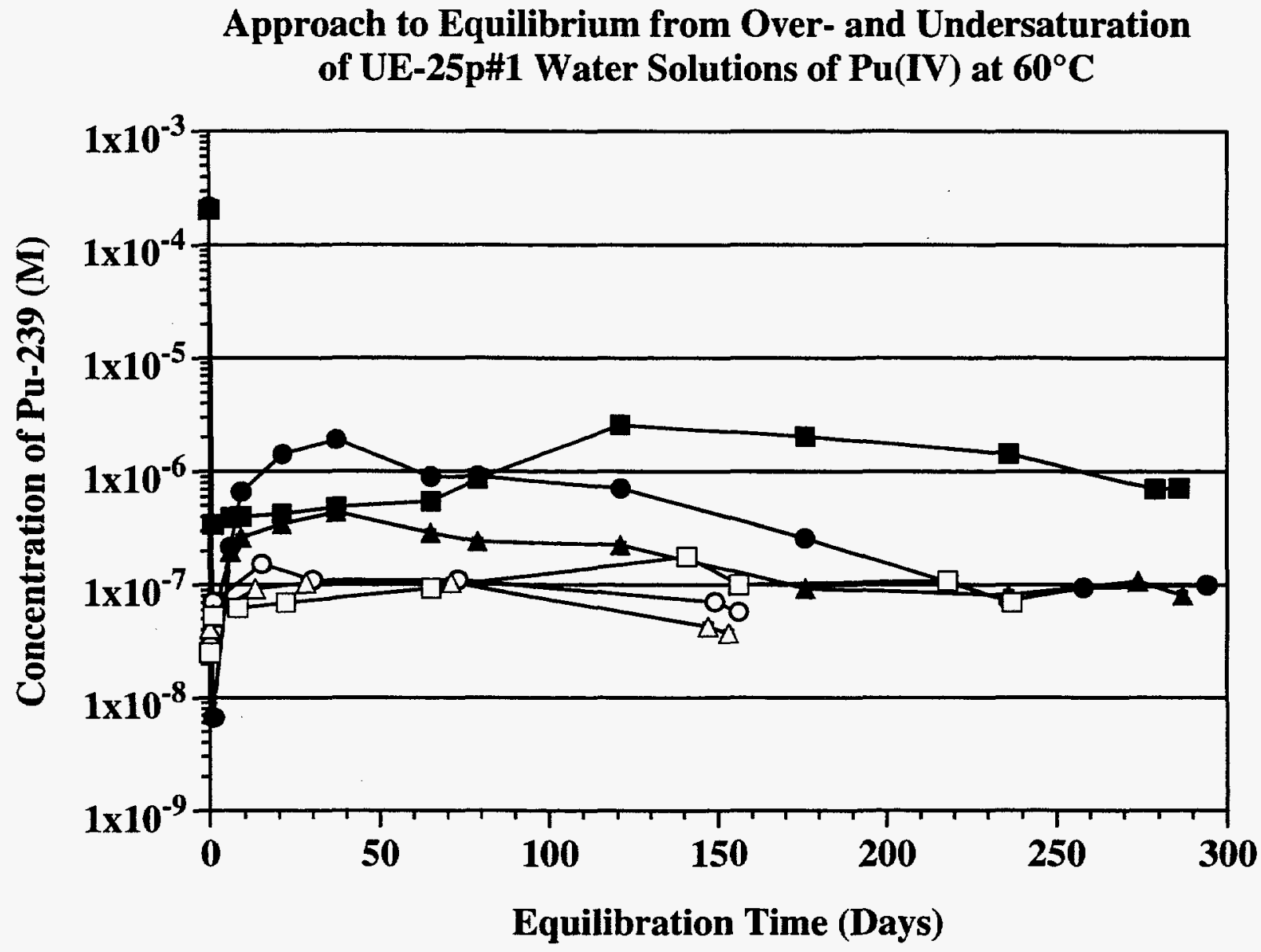

$\rightarrow \mathrm{pH} 6$, Oversaturation

-o- $\mathrm{pH}$ 6, Undersaturation

$\rightarrow \mathrm{pH} \mathrm{7,Oversaturation}$

$\neg-\mathrm{pH} 7$, Undersaturation

$\rightarrow \mathrm{pH} 8.5$, Oversaturation

$\neg-\mathrm{pH} 8.5$, Undersaturation

Figure 11 Solution concentrations of ${ }^{239} \mathrm{Pu}$ in contact with precipitate obtained from supersaturation of UE-25p \#1 groundwater at $60^{\circ} \mathrm{C}$ as a function of time. $\mathrm{pH} 6.0 \pm 0.1$ (closed circles), $\mathrm{pH} 7.0 \pm 0.1$ (closed triangles), and $\mathrm{pH} 8.5 \pm$ 0.1 (closed squares). The plutonium was added initially (day 0 ) as $\mathrm{Pu}^{4+}$; initial concentrations were $2.2 \times 10^{-4} \mathrm{M}(\mathrm{pH} \mathrm{6}), 2.2 \times 10^{-4} \mathrm{M}(\mathrm{pH} \mathrm{7)}$, and $2.0 \times 10^{-4} \mathrm{M}(\mathrm{pH} 8.5)$. Undersaturation experiments at $\mathrm{pH} 6.0$ (open circles), $\mathrm{pH} 7.0$ (open triangles), and $\mathrm{pH} 8.5$ (open squares) were started with precipitates obtained in the supersaturation experiments at their respective $\mathrm{pH}$ values. 


\subsubsection{Speciation}

The plutonium supernatant solutions at steady-state were analyzed for their oxidation state distributions. Speciation studies are made difficult by the low solubility of plutonium in UE-25p \#1 groundwater. The solutions' concentration levels lie below the sensitivity range of methods such as absorption spectrophotometry, which would allow the direct measurement of the species present. Therefore, we developed a method to determine the plutonium oxidation states indirectly. The method involves a combination of solvent extractions that allows us to determine the relative amounts of plutonium oxidation states in solution. Table XVII lists the methods used to determine the distribution of plutonium oxidation states in both the over- and undersaturation experiments at $60^{\circ} \mathrm{C}$.

Table XVII. Methods used for determining Plutonium oxidation states in solution.

\begin{tabular}{|c|c|c|c|}
\hline \multirow{2}{*}{\multicolumn{2}{|c|}{ Method }} & \multicolumn{2}{|c|}{ Oxidation State Distribution } \\
\hline & & Organic Phase & Aqueous Phase \\
\hline 1. & $\begin{array}{l}0.025 \mathrm{M} \text { PMBP Extraction at } \\
\mathrm{pH}=0\end{array}$ & $(+4)$ & $(+3,+5,+6, p)^{a}$ \\
\hline 2. & $\begin{array}{l}0.025 \mathrm{M} \text { PMBP Extraction at } \\
\mathrm{pH}=0 \text { with } \mathrm{Cr}_{2} \mathrm{O}_{7}^{2-}\end{array}$ & $(+3,+4)$ & $(+5,+6, p)^{\mathrm{a}}$ \\
\hline 3. & $\begin{array}{l}0.5 \mathrm{M} \text { HDEHP Extraction at } \\
\mathrm{pH}=0\end{array}$ & $(+4,+6)$ & $(+3,+5, \mathrm{p})^{\mathrm{a}}$ \\
\hline 4. & $\begin{array}{l}0.5 \mathrm{M} \text { HDEHP Extraction at } \\
\mathrm{pH}=0 \text { with } \mathrm{Cr}_{2} \mathrm{O}_{7}^{2-}\end{array}$ & $(+3,+4,+5,+6)$ & $(p)^{a}$ \\
\hline
\end{tabular}

(a) $(\mathrm{p})=\mathrm{Pu}(\mathrm{IV})$ polymer

For the experiments, we used 4-benzoyl-3-methyl-1-phenyl-2-pyrazolin-5-one (PMBP) as the extractant for $\mathrm{Pu}(\mathrm{IV})$. At $\mathrm{pH}$ 0, $\mathrm{PMBP}$ extracts $\mathrm{Pu}(\mathrm{IV})$ from aqueous solutions without significant decomposition by oxidants, such as dichromate. We used relatively small concentrations of extractant, therefore aiding in the nuclear counting of the fractions. Using PMBP and dichromate, we extract $\mathrm{Pu}(\mathrm{III})$ and $\mathrm{Pu}(\mathrm{IV})$ together by oxidation of $\mathrm{Pu}(\mathrm{III})$ to $\mathrm{Pu}(\mathrm{IV})$. At $\mathrm{pH} 0$, di-(2ethylhexyl)-orthophosphoric acid (HDEHP) extracts $\mathrm{Pu}(\mathrm{IV})$ and $\mathrm{Pu}$ (VI). Upon introducing dichromate to the aqueous phase before extraction, $\mathrm{Pu}(\mathrm{III})$ is oxidized to $\mathrm{Pu}(\mathrm{IV})$ and $\mathrm{Pu}(\mathrm{V})$ is oxidized to $\mathrm{Pu}(\mathrm{VI})$. HDEHP with dichromate extracts $\mathrm{Pu}(\mathrm{III}), \mathrm{Pu}(\mathrm{IV}), \mathrm{Pu}(\mathrm{V})$, and $\mathrm{Pu}$ (VI) by oxidation of $\mathrm{Pu}(\mathrm{III})$ to $\mathrm{Pu}(\mathrm{IV})$ and of $\mathrm{Pu}(\mathrm{V})$ to $\mathrm{Pu}(\mathrm{VI})$. The oxidation of $\mathrm{Pu}$ (III) to $\mathrm{Pu}(\mathrm{IV})$ is instantaneous when dichromate is introduced to the aqueous solution. After several hours, disproportionation and/or the oxidation of $\mathrm{Pu}(\mathrm{IV})$ to $\mathrm{Pu}(\mathrm{V})$ by dichromate may occur, however, 
experiments we conducted show the kinetics of these undesirable reactions are very slow and do not effect the extractions because they are completed in less than thirty minutes. This method was tested on plutonium solutions containing millimolar carbonate concentrations. The oxidation state distribution was measured at the same time by Laser Induced Photoacoustic Spectroscopy (LIPAS) and by our extraction method. ${ }^{38}$ In testing this method, we also performed extractions with 2-thenoyltrifluoroacetone (TTA) at $\mathrm{pH} 0$ in addition to the PMBP separations to verify that the two extractants produce the same results. At $\mathrm{pH} 0$, TTA also extracts $\mathrm{Pu}(\mathrm{IV})$ from aqueous solutions. In all cases the results were the same.

For the experiments, we tried to maintain the $60^{\circ} \mathrm{C}$ temperature as well as it was experimentally possible. Although we mixed the aqueous and organic phase for one minute at ambient temperature using a Vortex mixer, we separated the phases in a centrifuge heated to $60^{\circ} \mathrm{C}$. There is, however, the possibility that the oxidation state distributions at $60^{\circ} \mathrm{C}$ may have been affected by the handling-induced temperature change. Therefore, the derived results may be more semiquantitative.

In order to minimize the changing of plutonium oxidation states in solution, each of the extractions was carried out independently on a new solution sample. By taking differences in the relative amounts obtained in the four separations, the percent of each oxidation state can then be determined. Results of these studies are given in Table XVIII, and displayed in Figures 12, 13, and 14 , for $\mathrm{pH} 6,7$, and 8.5 , respectively.

The $60^{\circ} \mathrm{C}$ oversaturation solutions contained $\mathrm{Pu}(\mathrm{VI})$ almost completely. A small amount of $\mathrm{Pu}(\mathrm{IV})$ was present in the $\mathrm{pH} 8.5$ solution. $\mathrm{Pu}(\mathrm{III})$ and $\mathrm{Pu}(\mathrm{IV})$ polymer and $\mathrm{Pu}(\mathrm{V})$ were present in insignificant amounts. The $60^{\circ} \mathrm{C}$ undersaturation solutions were a little less consistent. In the pH 6 and $\mathrm{pH} 8.5$ solutions, the relative amounts of $\mathrm{Pu}(\mathrm{VI})$ dropped significantly and the $\mathrm{Pu}(\mathrm{V})$ percentage increased. Only the $\mathrm{pH} 7$ solution was completely consistent with its oversaturation counterpart within the error of the measurement.

The observed valence distributions cannot be explained by disproportionation equilibria and complex stabilization. ${ }^{39}$ It is possible that oxidation products formed by $\alpha$-radiolysis of the water may cause the predominance of higher oxidation states. It is noteworthy that the solutions were filtered through a $4.1 \mathrm{~nm}$ filter prior to the oxidation state determination because we wanted to determine only the true soluble plutonium fraction without any colloidal/polymeric plutonium being present. Therefore, we refer to the Pu(IV) polymer, in the context of this determination, as to the fraction that is smaller than $4.1 \mathrm{~nm}$. This colloidal or polymeric plutonium does not 
participate in the ionic solution equilibrium, and its removal will not immediately affect the oxidation state distribution in the solution ${ }^{40}$.

Another possible explanation for the predominance of high oxidation states at steady-state may lie in the plutonium stock solution itself. Because of the limits of detection associated with our spectrophotometer, the solubility experiments may have contained initial concentrations of $\mathrm{Pu}(\mathrm{III}), \mathrm{Pu}(\mathrm{V})$, and $\mathrm{Pu}(\mathrm{VI})$ as high as $2 \times 10^{-6}, 6 \times 10^{-6}$, and $2 \times 10^{-7} \mathrm{M}$, respectively. These concentrations could result based on the maximum concentrations that would have been undetected in the $10^{-2} \mathrm{M} \mathrm{Pu}(\mathrm{IV})$ stock solution. Assuming complete precipitation of the lower oxidation states, one could conclude that the potential initial concentrations of $\mathrm{Pu}(\mathrm{V})$ and $\mathrm{Pu}(\mathrm{VI})$ may represent the steady-state oxidation state distributions and the total aqueous plutonium concentrations. However, after completing oxidation state determinations in the corresponding plutonium undersaturation experiments in UE-25p \#1 groundwater at $60^{\circ} \mathrm{C}$, the above speculation cannot be confirmed, that trace level oxidation state impurities in the stock solution used to start the oversaturation experiments may be causing the plutonium solubility limits and the oxidation state distribution in solution. The undersaturation experiments were started with only the solid phases obtained in the oversaturation experiments. The results from oxidation state determinations on the undersaturation experiments showed combined relative amounts for $\mathrm{Pu}(\mathrm{V})$ and $\mathrm{Pu}(\mathrm{VI})$ of $96 \%, 98 \%$, and $90 \%$ for solutions at $\mathrm{pH} 6,7$, and 8.5 , respectively. The undersaturation experiment at $\mathrm{pH} 8.5$ also showed a small amount of $\mathrm{Pu}(\mathrm{IV})$, approximately $10 \%$. This finding is in excellent agreement with the result from the corresponding oversaturation experiment at $\mathrm{pH}$ 8.5. We also note that the slightly lower, yet still oxic, Eh value measured for the $\mathrm{pH} 6$ and 8.5 experiments also support the increased presence of $\mathrm{Pu}(\mathrm{IV})$ and $\mathrm{Pu}(\mathrm{V})$. Here again, all three measurements were reproduced in the corresponding undersaturation experiments to within $21 \mathrm{mV}$.

In light of this, the predominance of higher oxidation states appears to be a real effect, yet more investigation into the species responsible for the oxidation of the plutonium in solution is desirable. 
Table XVIII. Plutonium oxidation state determinations in UE-25p \#1 at pH values 6, 7, and 8.5 and $60^{\circ} \mathrm{C}$.

\begin{tabular}{|c|c|c|c|c|c|c|c|c|}
\hline \multirow{3}{*}{ pH } & \multicolumn{9}{|c|}{ Oxidation States (\%) } \\
\cline { 2 - 10 } & $\begin{array}{r}\text { Pu(IV)-polymer }+ \\
\text { Pu(II) }\end{array}$ & \multicolumn{2}{|c|}{ Pu(IV) } & \multicolumn{2}{c|}{ Pu(V) } & \multicolumn{2}{c|}{ Pu(VI) } \\
\cline { 2 - 10 } & Over & Under & Over & Under & Over & Under & Over & Under \\
\hline \hline 6 & $(1 \pm 1)$ & $(1 \pm 1)$ & $(1 \pm 1)$ & $(2 \pm 1)$ & $(4 \pm 1)$ & $(39 \pm 4)$ & $(94 \pm 11)$ & $(57 \pm 6)$ \\
\hline 7 & $(2 \pm 1)$ & $(1 \pm 1)$ & $(1 \pm 1)$ & $(1 \pm 1)$ & $(5 \pm 1)$ & $(9 \pm 2)$ & $(93 \pm 11)$ & $(89 \pm 10)$ \\
\hline 8.5 & $(5 \pm 2)$ & $(0)$ & $(10 \pm 1)$ & $(10 \pm 2)$ & $(0)$ & $(36 \pm 4)$ & $(86 \pm 12)$ & $(54 \pm 7)$ \\
\hline
\end{tabular}


Plutonium Oxidation State Distributions in UE-25p\#1

Water from Over- and Undersaturation at $60^{\circ} \mathrm{C}$ and $\mathrm{pH} 6$

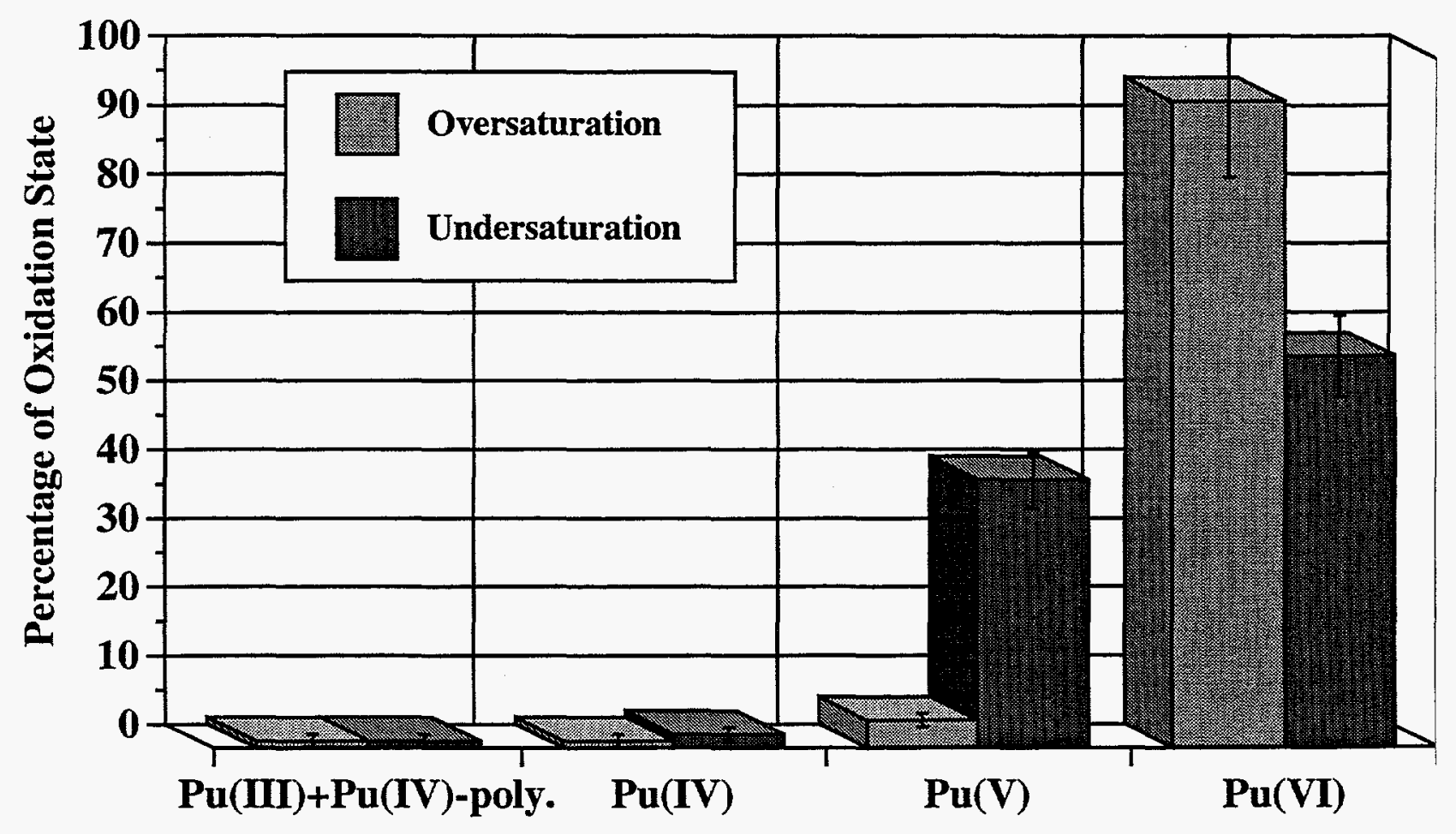

Oxidation State

Figure 12. Plutonium oxidation state distributions of the supernatant at steady-state for $\mathrm{Pu}^{4+}$ solubility experiments from over- and undersaturation in UE-25p \#1 groundwater at $\mathrm{pH} 6$ and $60^{\circ} \mathrm{C}$. The solutions were filtered through $4.1 \mathrm{~nm}$ filters. 


\section{Plutonium Oxidation State Distributions in UE-25p\#1 Water from Over- and Undersaturation at $60^{\circ} \mathrm{C}$ and $\mathrm{pH} 7$}

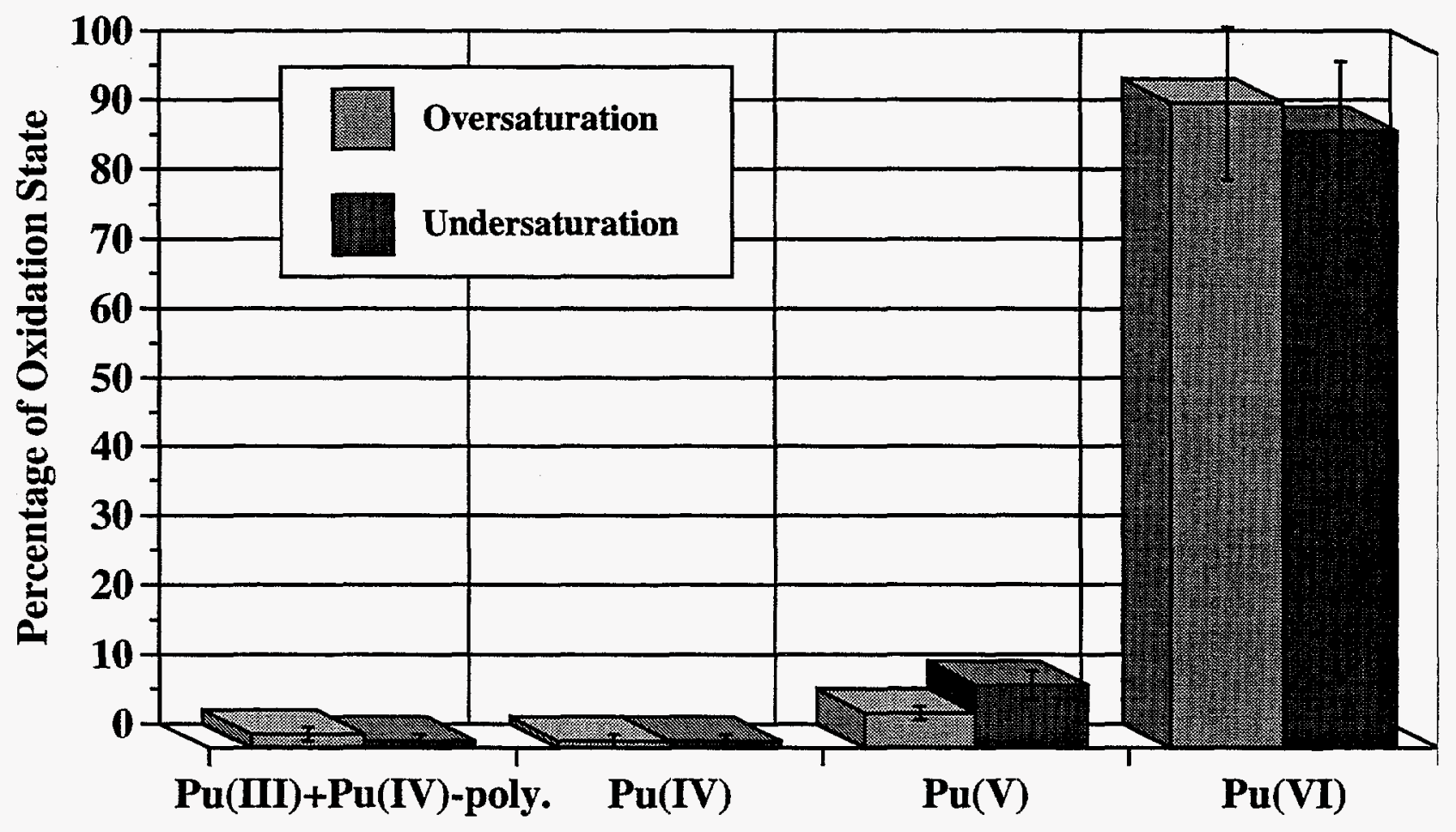

\section{Oxidation State}

Figure 13. Plutonium oxidation state distributions of the supernatant at steady-state for $\mathrm{Pu}^{4+}$ solubility experiments from over- and undersaturation in UE-25p \#1.groundwater at $\mathrm{pH} 7$ and $60^{\circ} \mathrm{C}$. The solutions were filtered through $4.1 \mathrm{~nm}$ filters. 
Plutonium Oxidation State Distributions in UE-25p\#1 Water from Over- and Undersaturation at $60^{\circ} \mathrm{C}$ and $\mathrm{pH} 8.5$

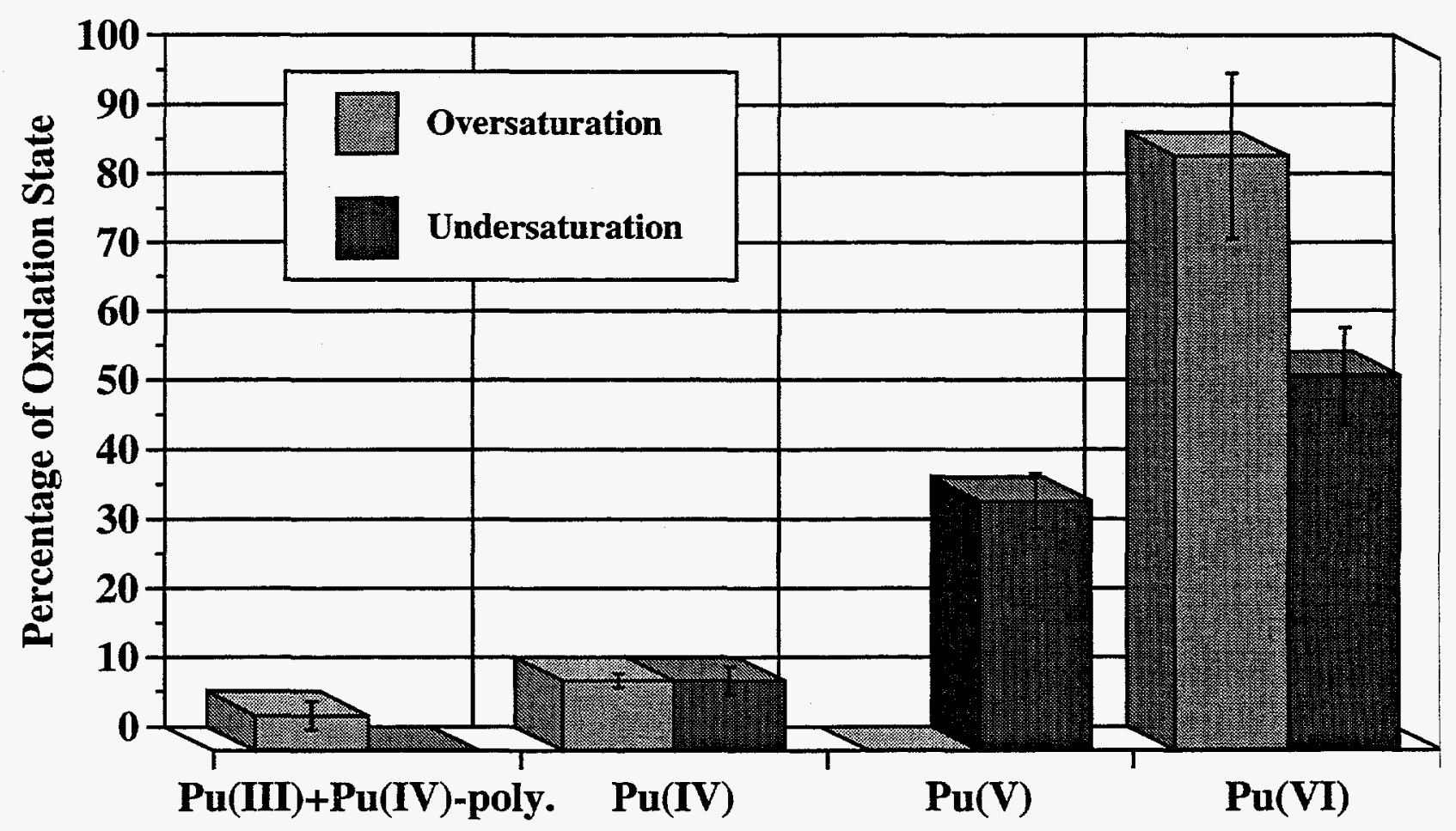

\section{Oxidation State}

Figure 14. Plutonium oxidation state distributions of the supernatant at steady-state for $\mathrm{Pu}^{4+}$ solubility experiments from over- and undersaturation in UE-25p \#1 groundwater at $\mathrm{pH} 8.5$ and $60^{\circ} \mathrm{C}$. The solutions were filtered through $4.1 \mathrm{~nm}$ filters. 


\subsubsection{Identification of Solids}

The plutonium precipitates from both over- and undersaturation solutions were collected by centrifugation, washed with a small amount of $\mathrm{CO}_{2}$-free water, and dried with a jet of argon. All precipitates from the oversaturation experiments were a light brown-slightly greenish color. All precipitates from the undersaturation experiments were a very light brown color. Crystal lattice $d$ spacings and relative intensities of the $x$-ray powder diffraction patterns from the precipitates are listed in Table XIX.

The plutonium solid from the oversaturation experiment at $\mathrm{pH} 6$ showed only a diffuse band indicating a low degree of crystallinity, which may be indicative of $\mathrm{Pu}(\mathrm{IV})$-polymer. The powder pattern from the solid obtained in the $\mathrm{pH} 7$ experiment showed the same diffuse band plus one weak line at $3.03 \AA$. Again, this shows a very low degree of crystallinity and is consistent with results for polymeric $\mathrm{Pu}(\mathrm{IV})$. The solid from the $\mathrm{pH} 8.5$ experiment at $60^{\circ} \mathrm{C}$ produced a powder pattern that contained 7 diffraction lines. All of the diffraction lines were weak and trace lines with the exception of one, at a d-spacing of $3.26 \AA$. This powder pattern was compared to patterns of crystalline $\mathrm{PuO}_{2}{ }^{41}, \mathrm{PuO}_{3} \cdot 0.8 \mathrm{H}_{2} \mathrm{O}^{42}, \mathrm{KPuO}_{2} \mathrm{CO}_{3}{ }^{43}, \mathrm{NH}_{4} \mathrm{PuO}_{2} \mathrm{CO}_{3}{ }^{43}$, and $\mathrm{PuO}_{2} \mathrm{CO}_{3} 44$. No match was found among these patterns, so all we can conclude is that the solid obtained at $\mathrm{pH}$ 8.5 and $60^{\circ} \mathrm{C}$ is crystalline but cannot be identified.

The plutonium solids removed from the solubility cells after completion of the undersaturation experiment are somewhat different. The $\mathrm{pH} 6$ solid gave five distinct diffraction lines, all at least weak in intensity, and the $\mathrm{pH} 7$ solid gave six distinct lines. Both of these results indicate that a more crystalline solid formed. The $\mathrm{pH} 8.5$ solid gave six lines in its diffraction pattern. These lines were completely different from those obtained from the $\mathrm{pH} 8.5$ oversaturation solid. All three solids where compared to patterns of crystalline $\mathrm{PuO}_{2}{ }^{41}, \mathrm{PuO}_{3} \cdot 0.8 \mathrm{H}_{2} \mathrm{O}^{42}, \mathrm{KPuO}_{2} \mathrm{CO}_{3}{ }^{43}$, $\mathrm{NH}_{4} \mathrm{PuO}_{2} \mathrm{CO}_{3}{ }^{43}$, and $\mathrm{PuO}_{2} \mathrm{CO}_{3}{ }^{44}$. No match was found among these patterns, so all we can conclude is that the solids are crystalline but not yet identified. The solids obtained from the undersaturation experiments gave diffraction patterns that matched each other very well and it appears that a similar solid was formed in at all three pH's.

In summary, the solids formed from oversaturation at $\mathrm{pH} 6$ and 7 appear to be amorphous $\mathrm{Pu}(\mathrm{IV})$-polymer; whereas, the solids produced from oversaturation at $\mathrm{pH} 8.5$ and from undersaturation at all $\mathrm{pH}$ 's are crystalline but unidentified. 
Table XIX. X-ray powder diffraction patterns of plutonium solid phases from oversaturation in UE-25p \#1 ground water at $60^{\circ} \mathrm{C}$ and $\mathrm{pH} 6,7$, and 8.5.

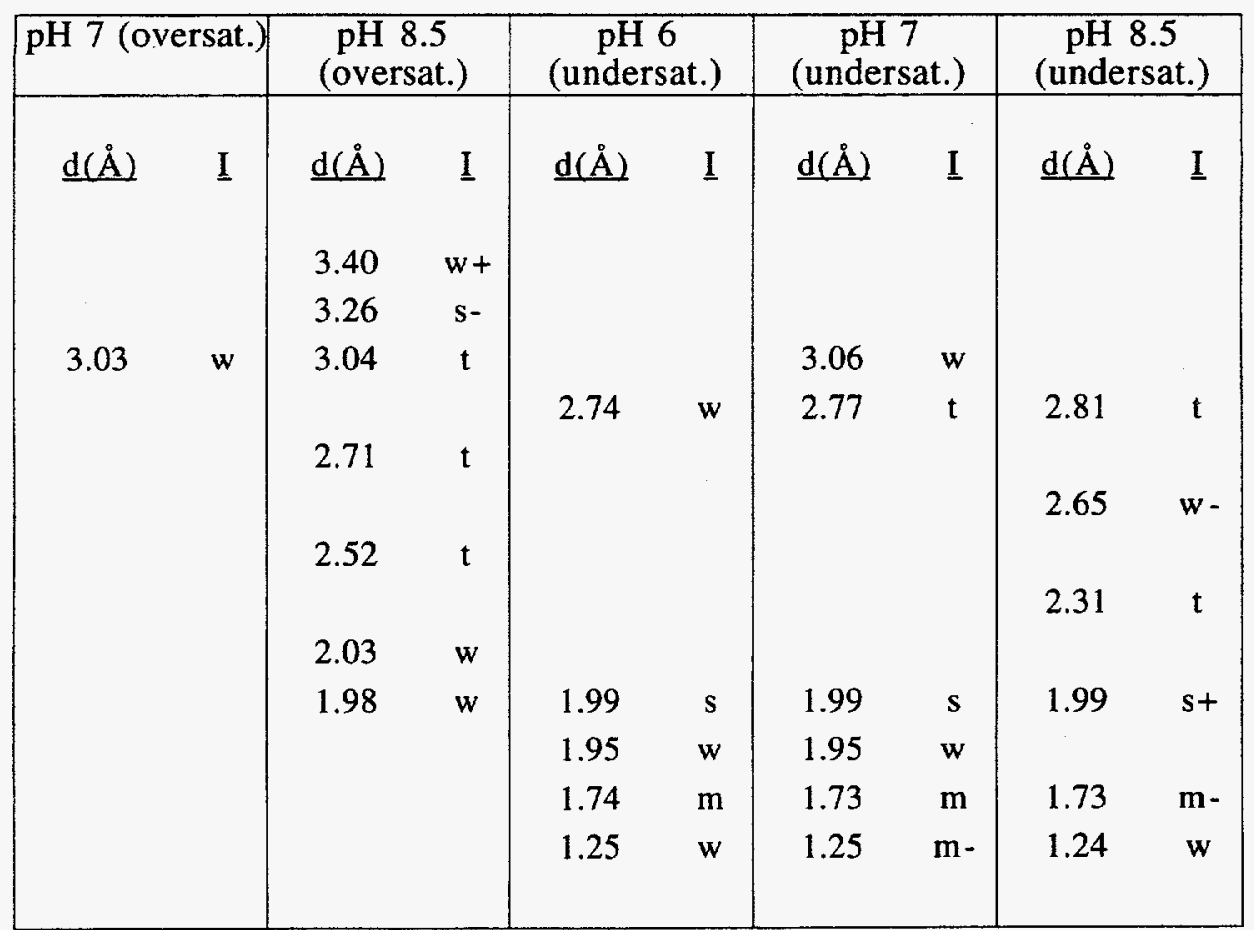

(a) Relative intensities visually estimated: $v s=$ very strong, $s=$ strong, $\mathrm{m}=$ medium, $\mathrm{w}=$ weak, $\mathrm{t}=$ trace. 


\subsection{Americium}

We used non-radioactive neodymium in place of americium to minimize radiation-induced degradation of the solubility cell. Neodymium is chemically similar to americium. ${ }^{45}$ It has an ionic radius of $0.983 \AA$ that is very close to that of $0.975 \AA$ for trivalent americium. ${ }^{46}$ The neodymium was spiked with a small amount of ${ }^{241} \mathrm{Am}$ to facilitate sample counting using the 59.54-keV photo-peak. The use of the neodymium spiked with ${ }^{241} \mathrm{Am}$ tracer reduced the alpharadiation to a fraction of the radiation that would have been present if we had used pure ${ }^{243} \mathrm{Am}$. The mole ratio $(([\mathrm{Am}]+[\mathrm{Nd}]) /[\mathrm{Am}])$ used in these solubility experiments was 113.7:1.

We confirmed in an earlier study that neodymium is a good stand-in element for americium. ${ }^{1}$ The differences between the solubilities of $\mathrm{Nd} / 241 \mathrm{Am}$ and pure ${ }^{243} \mathrm{Am}$ were insignificant at each of the studied $\mathrm{pH}$ values. This validates our solubility tests in UE-25p \#1 groundwater at $60^{\circ} \mathrm{C}$ where we used neodymium mixed with trace amounts of ${ }^{241} \mathrm{Am}$ as a substitute for ${ }^{243} \mathrm{Am}$.

5.3.1. Solubility. Results of the solubility studies are shown in Figure 15 . The steady-state concentrations and the solutions' Eh values are given in Table XX. Concentration profiles as a function of equilibration time and $\mathrm{pH}$ for both the over- and undersaturation experiments are shown in Figure 16. Individual measurements are listed in Appendix C. Results for the americium/neodymium solubility experiment from oversaturation at $\mathrm{pH} 7$ are incomplete because the experiment was stopped early due to equipment failure. The test cell, equipped with a faulty O-ring, allowed the experimental solution to evaporate. Steady-state may not have been reached, and the solution concentration reported in Table XX was determined from only the last two samplings. However, the steady-state concentration values from the undersaturation experiment are nearly identical to the steady-state concentration values from the oversaturation experiment, confirming that the solution was very near steady-state. 


\section{Americium(III)/Neodymium Solubility Experiments from Over- and Undersaturation in UE-25p\#1 Water at $60^{\circ} \mathrm{C}$}

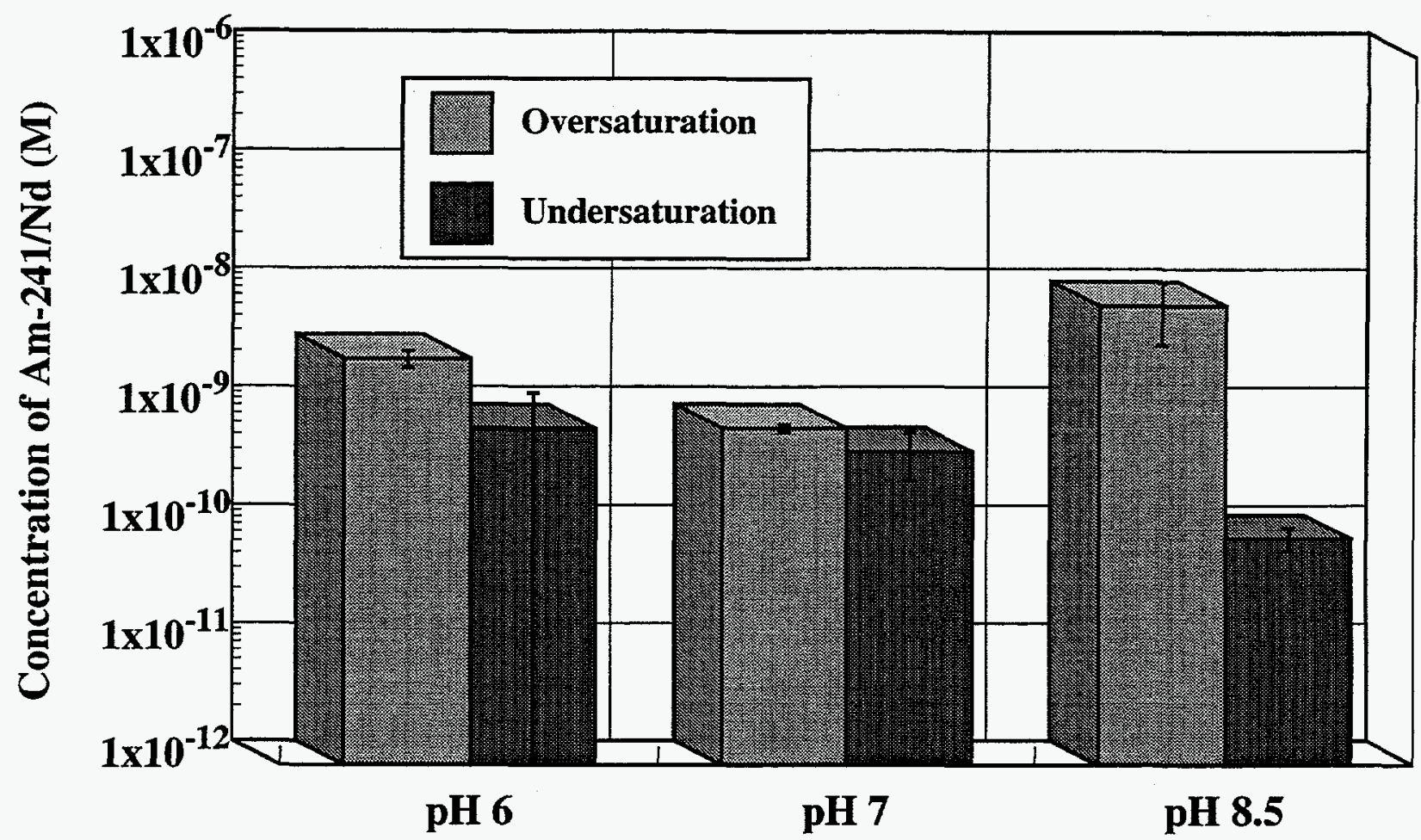

Figure 15. Results for ${ }^{241} \mathrm{Am}^{3+} / \mathrm{Nd}^{3+}$ solubility experiments from over- and undersaturation in UE-25p \#1 groundwater at $60^{\circ} \mathrm{C}$ as a function of $\mathrm{pH}$.

Table XX. Comparison of steady-state solution concentrations and Eh for americium/ neodymium from over- and undersaturation in UE-25p \#1 water at $60^{\circ} \mathrm{C}$.

\begin{tabular}{|c|c|c|c|c|}
\hline \multirow{2}{*}{$\mathrm{pH}$} & \multicolumn{4}{|c|}{ Americium(III)/Neodymium } \\
\cline { 2 - 5 } & \multicolumn{2}{|c|}{ Concentration (M) } & \multicolumn{2}{c|}{ Eh (mV vs. NHE) } \\
\cline { 2 - 5 } & Oversaturation & Undersaturation & Oversaturation & Undersaturation \\
\hline \multirow{2}{*}{6} & $(2.7 \pm 0.4) \times 10^{-9}$ & $(7.0 \pm 7.3) \times 10^{-10}$ & $(370 \pm 15)$ & $(394 \pm 15)$ \\
\hline 7 & $(7.1 \pm 0.5) \times 10^{-10}$ & $(4.6 \pm 2.0) \times 10^{-10}$ & $(\mathrm{NA})$ & $(430 \pm 15)$ \\
\hline 8.5 & $(7.8 \pm 4.3) \times 10^{-9}$ & $(8.4 \pm 1.8) \times 10^{-11}$ & $(220 \pm 15)$ & $(215 \pm 15)$ \\
\hline
\end{tabular}




\section{Approach to Equilibrium from Over- and Undersaturation of UE-25p\#1 Water Solutions of Am(III)/Nd at $60^{\circ} \mathrm{C}$}

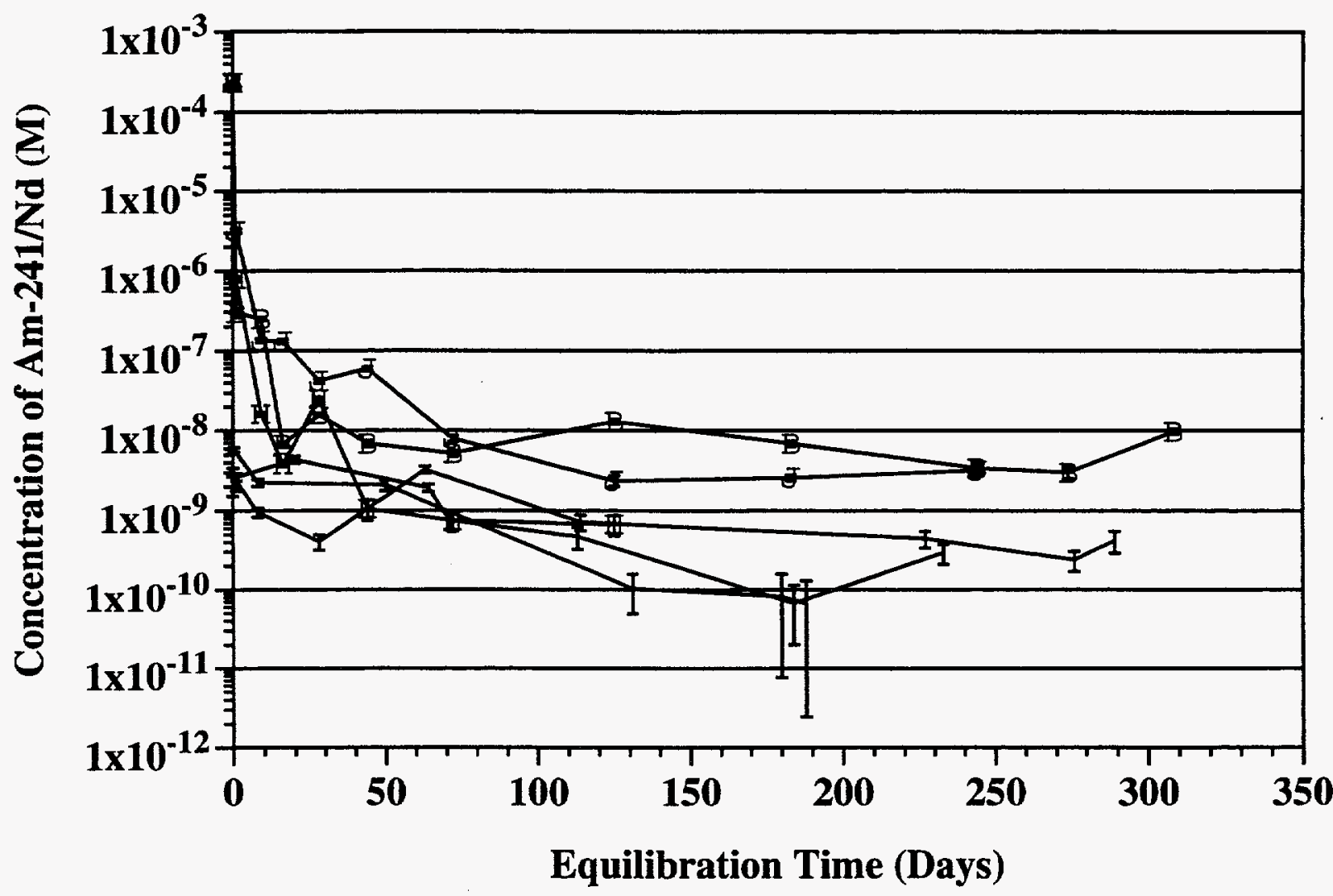

\section{J $\mathrm{pH}$, Oversaturation \\ - $\mathrm{pH}$ 6, Undersaturation \\ If $\mathrm{pH} 7$, Oversaturation \\ - $\mathrm{pH} 7$, Undersaturation \\ $\rightarrow \mathrm{pH} 8.5$, Oversaturation \\ $\mathrm{pH} 8.5$, Undersaturation}

Figure 16. Solution concentrations of ${ }^{241} \mathrm{Am} / \mathrm{Nd}$ in contact with precipitate obtained from supersaturation of UE-25p \#1 groundwater at $60^{\circ} \mathrm{C}$ as a function of time. $\mathrm{pH} 6.0$ \pm 0.1 (closed circles), $\mathrm{pH} 7.0 \pm 0.1$ (closed triangles), and $\mathrm{pH} 8.5 \pm 0.1$ (closed squares). The americium/neodymium was added initially (day 0 ) as ${ }^{241} \mathrm{Am}^{3+} / \mathrm{Nd}^{3+}$; initial $\left({ }^{241} \mathrm{Am}^{3+}+\mathrm{Nd}^{3+}\right)$ concentrations were $2.3 \times 10^{-4} \mathrm{M}(\mathrm{pH}$ 6), $2.3 \times 10^{-4} \mathrm{M}\left(\mathrm{pH} \mathrm{7)}\right.$, and $2.3 \times 10^{-4} \mathrm{M}(\mathrm{pH} 8.5)$. Undersaturation experiments at $\mathrm{pH} 6.0$ (open circles), $\mathrm{pH} 7.0$ (open triangles), and $\mathrm{pH} 8.5$ (open squares) were started with precipitates obtained in the supersaturation experiments at their respective $\mathrm{pH}$ values. 
Results for americium/neodymium filtration experiments have been given elsewhere. ${ }^{32}$ The filtration experiments are described in Section 4.5. Filtration experiments on day one of the $60^{\circ} \mathrm{C}$ oversaturation experiments at $\mathrm{pH} 6,7$, and 8.5 required 500,1500 , and $2500 \mu \mathrm{L}$, respectively, as preconditioning volumes. Toward the end of the $60^{\circ} \mathrm{C}$ oversaturation experiments, as concentrations dropped from $10^{-8}$ to $10^{-10} \mathrm{M}$, we routinely used $2500 \mu \mathrm{L}$ as a presaturation volume for all experiments to ensure adequate saturation of the filters before sampling. We repeated the filtration experiments for the undersaturation cells and confirmed that indeed 2500 $\mu \mathrm{L}$ was a sufficient preconditioning volume to use over the time of the entire solubility experiment.

In summary, the solubility of americium/neodymium from over- and undersaturation at $\mathrm{pH} 6$ and 7 agreed within the error of the measurements. The $\mathrm{pH} 8.5$ experiment from undersaturation was nearly two orders of magnitude less soluble than its oversaturation counterpart. This result shows that the steady-state condition may not have been reached in the oversaturation cell at $\mathrm{pH} 8.5$. It appears that the americium/neodymium concentration from the first few days of the undersaturation experiment continued at the level of the final assays from the oversaturation experiment. In time, the concentration dropped by two orders of magnitude and a new steadystate condition was reached. The solubility of americium/neodymium showed no trend with $\mathrm{pH}$ in the oversaturation experiment, but showed decreasing concentration with increasing $\mathrm{pH}$ in the undersaturation experiment. If we assume that steady-state was not reached for the $\mathrm{pH} 8.5$ cell until after day 125 of the undersaturation experiment, then the dependence of the concentration on the $\mathrm{pH}$ is confirmed.

5.3.2. Speciation. Speciation measurements could not be carried out because of the low solution concentrations. The trivalent neodymium is expected, under these experimental conditions, not to change its oxidation state. In determining whether the ${ }^{241} \mathrm{Am}$ tracer undergoes a change in oxidation state, we used extractions with $0.5 \mathrm{M}$ thenoyltrifluoroacetone (TTA) or $0.025 \mathrm{M} 1$ phenyl-3-methyl-4-benzoyl-pyrazolin-5-one (PMBP) at $\mathrm{pH} 0$ and coprecipitations with $\mathrm{LaF}_{3}$. TTA or PMBP extracts the oxidation state IV and leaves the oxidation states III, V, and VI in the aqueous solution. The lanthanum fluoride (with holding oxidant) coprecipitates the oxidation states III and IV, and leaves the V and VI in the supernatant. As could be expected for the experimental conditions, we found no higher americium oxidation states. The trivalent americium did not change its oxidation state.

5.3.3. Identification of Solids. The neodymium/americium- 241 precipitates found in both experiments were collected by centrifugation, washed with a small amount of $\mathrm{CO}_{2}$-free water, 
dried with an argon jet, and analyzed by x-ray powder diffraction. The crystal lattice $\mathrm{d}$-spacings and relative intensities of all of the solids obtained are listed in Table XXI.

The solids from oversaturation were analyzed in an earlier report. ${ }^{32}$ They were found to be mixtures of $\mathrm{Nd}_{2}\left(\mathrm{CO}_{3}\right)_{3} \cdot 2 \mathrm{H}_{2} \mathrm{O}$ and orthorhombic $\mathrm{NdOHCO}_{3}$ in the case of the $\mathrm{pH} 7$ and 8.5 solids. The $\mathrm{pH} 6$ solid yielded very few lines and was considered to be "possibly a mixture of $\mathrm{Nd}_{2}\left(\mathrm{CO}_{3}\right)_{3} \cdot 2 \mathrm{H}_{2} \mathrm{O}$ and hexagonal $\mathrm{NdOHCO}_{3}$ ". It was shown in the literature that americium hydroxycarbonates are isostructural to the analogous neodymium hydroxycarbonates. $45,47,48$ The $\mathrm{pH} 6$ undersaturation solid produced many more diffraction lines than the solid from oversaturation. With these additional lines it appears that the solid formed is a mixture of $\mathrm{Nd}_{2}\left(\mathrm{CO}_{3}\right)_{3} \cdot 2 \mathrm{H}_{2} \mathrm{O}$ and orthorhombic $\mathrm{NdOHCO}_{3}$, as was found in the $\mathrm{pH} 7$ and $\mathrm{pH} 8.5$ oversaturation solids. The $\mathrm{pH} 7$ undersaturation solid yielded fewer lines in its diffraction pattern than the solid obtained from oversaturation. However, the lines that are present fit well with both the $\mathrm{pH} 7$ and $\mathrm{pH} 8.5$ oversaturation solids. Again, it appears to be a mixture of $\mathrm{Nd}_{2}\left(\mathrm{CO}_{3}\right)_{3} \cdot 2$ $\mathrm{H}_{2} \mathrm{O}$ and orthorhombic $\mathrm{NdOHCO}_{3}$. The $\mathrm{pH} 8.5$ undersaturation solid fits well with the $\mathrm{pH} 8.5$ oversaturation solid. The solid from undersaturation has fewer trace lines probably due to shorter exposure times. This solid fits well with the $\mathrm{Nd}_{2}\left(\mathrm{CO}_{3}\right)_{3} \cdot 2 \mathrm{H}_{2} \mathrm{O}^{45}$ solid, but still has some lines in common with the orthorhombic form of $\mathrm{NdOHCO}_{3} \cdot{ }^{48} \mathrm{~A}$ comparison of all solids obtained in the undersaturation experiments with the reference patterns of: 1.) $\mathrm{Nd}_{2}\left(\mathrm{CO}_{3}\right)_{3} \cdot 2 \mathrm{H}_{2} \mathrm{O}^{45}$; and 2.) orthorhombic $\mathrm{NdOHCO}_{3}{ }^{48}$ are shown in Table XXII.

With regard to literature reference patterns containing diffraction lines with d-spacings larger than $6 \AA$, we have found that with the published powder patterns for hydrated neptunium solids, strong lines with large d-spacings were influenced by varying hydrate content in the solid. If the solids from the $\mathrm{Am} / \mathrm{Nd}$ experiments contained $\mathrm{Nd}_{2}\left(\mathrm{CO}_{3}\right)_{3}$ with a varying hydrate content and the diffraction characteristic of hydrate water behaves as it does in neptunium solids, then we may in fact see some diffraction lines at d-spacings greater than 10-12 $\AA$. The only conclusion we can draw at this point regarding the solids produced is that they appear to be mixtures of orthorhombic $\mathrm{NdOHCO}_{3}$ and $\mathrm{Nd}_{2}\left(\mathrm{CO}_{3}\right)_{3} \cdot 2 \mathrm{H}_{2} \mathrm{O}$ with possibly varying water content.

In summary, the UE-25p \#1 solubility experiments at all pH's appear to have produced a mixture of orthorhombic $\mathrm{NdOHCO}_{3}$ and $\mathrm{Nd}_{2}\left(\mathrm{CO}_{3}\right)_{3} \cdot 2 \mathrm{H}_{2} \mathrm{O}$ with possibly varying water content. 
Table XXI. X-ray powder diffraction patterns of $\mathrm{Nd} /{ }^{241} \mathrm{Am}$ solid phases in UE-25p \#1 groundwater from over- and undersaturation at $60^{\circ} \mathrm{C}$ and $\mathrm{pH} 6,7$, and 8.5 .

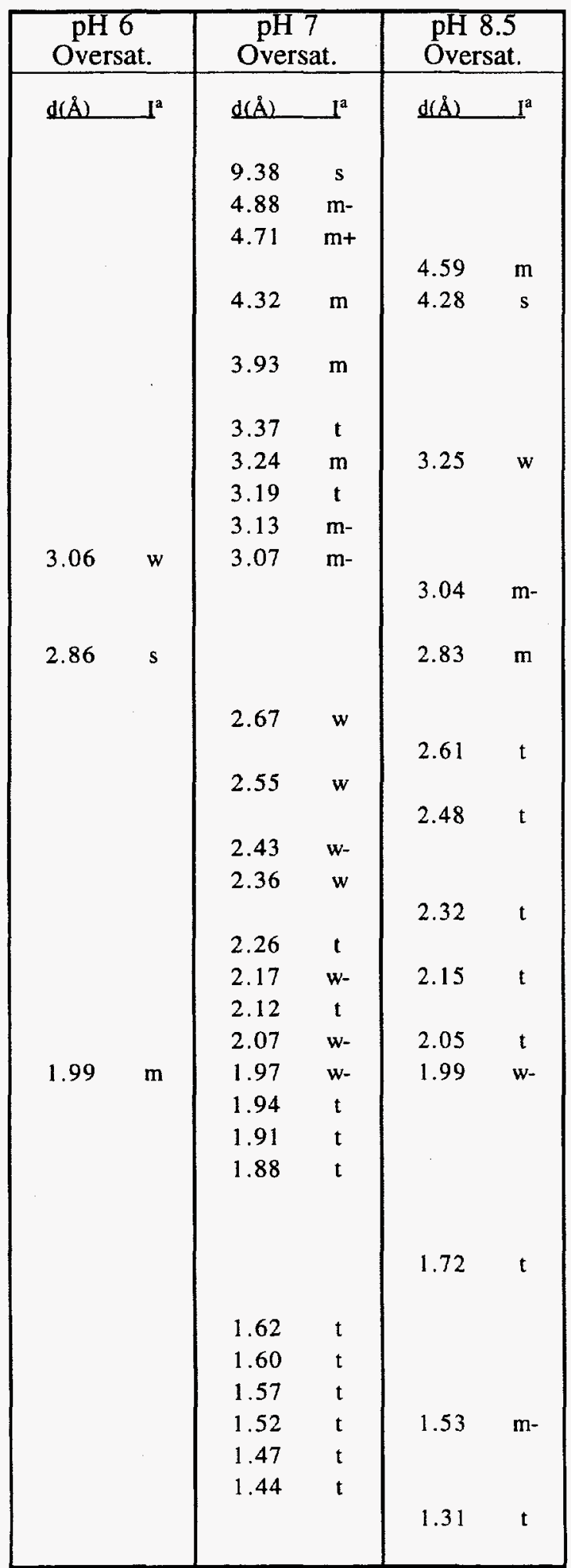

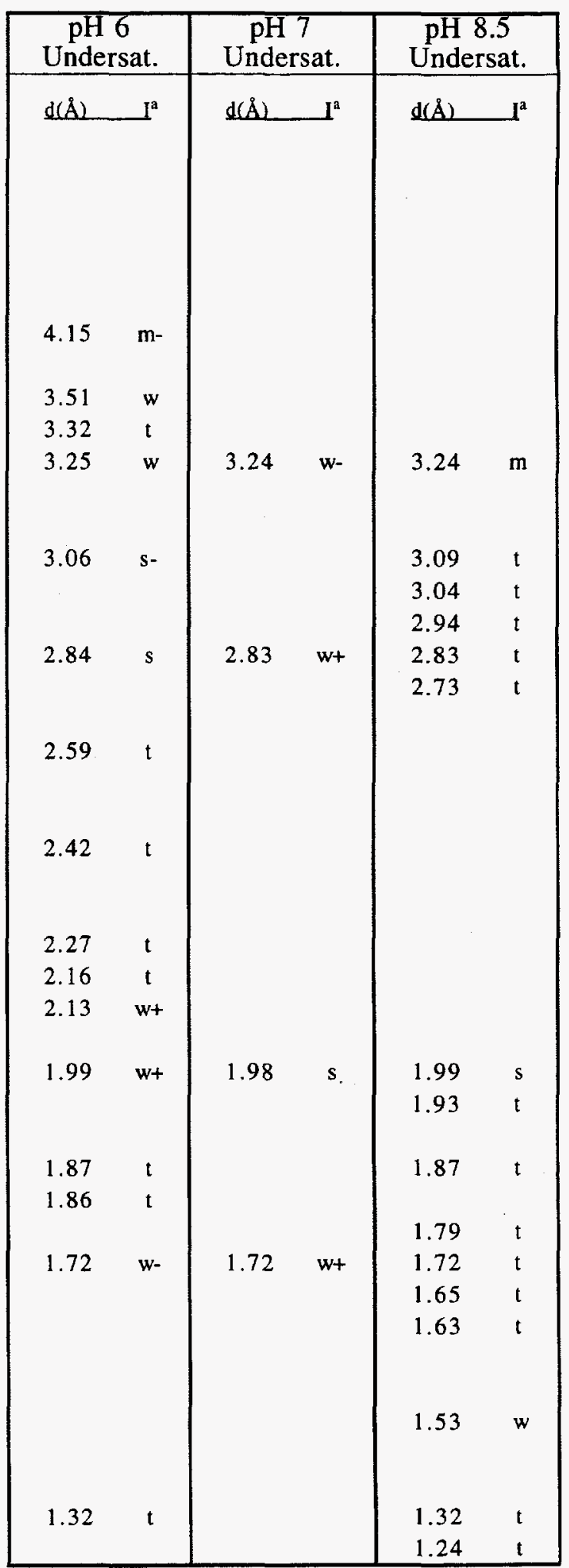

(a) Relative intensities visually estimated: $v s=$ very strong, $s=$ strong, $m=$ medium, $w=w e a k, t=$ trace. 
Table XXII. X-ray powder diffraction patterns of $\mathrm{Nd} /{ }^{241} \mathrm{Am}$ solid phases in UE-25p \#1 groundwater from undersaturation at $60^{\circ} \mathrm{C}$ and $\mathrm{pH} 6,7$, and 8.5 compared with reference patterns of: 1.) $\mathrm{Nd}_{2}\left(\mathrm{CO}_{3}\right)_{3} \cdot 2 \mathrm{H}_{2} \mathrm{O} ; 2$.) orthorhombic $\mathrm{NdOHCO}_{3} \cdot{ }^{45,48}$

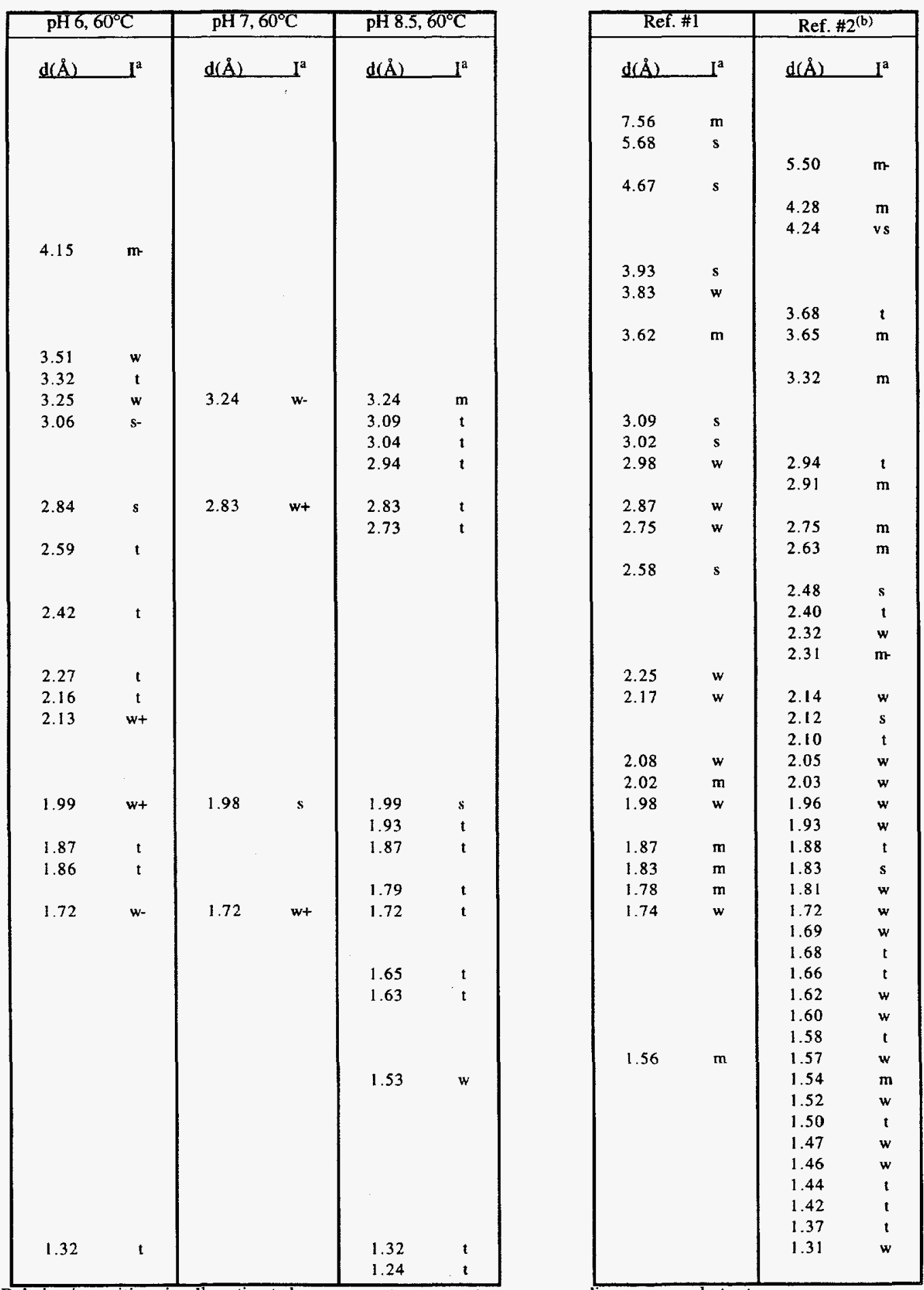

(a) Relative intensities visually estimated: $v s=$ very strong, $s=$ strong, $m=$ medium, $w=$ weak, $t=$ trace.

(b) Ref. \#3 contains 7 more "weak" and "trace" lines with $d$-spacings smaller than $1.31 \AA$ that are not listed. 


\section{REFERENCES}

1. H. Nitsche, R.C. Gatti, E.M. Standifer, S.C. Lee, A. Müller, T. Prussin, R.S. Deinhammer, H. Mauer, K. Becraft, S. Leung, and S.A. Carpenter, "Measured Solubilities and Speciations of Neptunium, Plutonium, and Americium in a Typical Groundwater (J-13) from the Yucca Mountain Region," report LBL-30958, Milestone Report 3010, Lawrence Berkeley Laboratory, California (1992). NNA.930507.0136

2. U.S. Department of Energy Yucca Mountain Site Characterization Plan, Yucca Mountain Site, Nevada Research and Development Area, Nevada, Office of Civilian Radioactive Waste Management, Washington, D.C. (1988). HQO.881201.0002

3. D.J. Brooks and J.A. Corrado, "Determination of Radionuclide Solubility in Groundwater for Assessment of High-Level Waste Isolation," U.S. Nuclear Regulatory Commission, Technical Position, Washington, D.C. (1984). NNA.871104.0035

4. A.E. Ogard and J.F. Kerrisk, "Groundwater Chemistry Along the Flow Path between a Proposed Repository Site and the Accessible Environment," report LA10188-MS, Los Alamos National Laboratory, New Mexico (1984). NNA.870406.0021

5. J.K. Johnstone, R.R. Peters, and P.F. Gnirk, "Unit Evaluation of Yucca Mountain, Nevada Test Site: Summary Report and Recommendations," report SAND-83-0372, Sandia National Laboratories, Albuquerque, New Mexico (1984). NNA.870519.0052

6. B.V. Enüstün, J. Turevich, "Solubility of Fine Particles of Strontium Sulfate," J. Amer. Chem. Soc. 82, $4502-4509$ (1960). NNA.930326.0103

7. P.W. Vorhees, "The Theory of Ostwald Ripening," J. Stat. Phys. 38, 231-252 (1985). NNA.930326.0102

8. J.W. Morse, W.H. Casey, "Ostwald Processes and Mineral Paragenesis in Sediments," Amer. J. Sci. 288, 537-560 (1980). NNA.930326.0101

9. J.A. Rard, "The Effect of Precipitation Conditions and Aging upon Characteristics of Particles Precipitated from Aqueous Solutions," report UCID-21755, Lawrence Livermore National Laboratory, Livermore, California, U.S.A. (1989).

NNA.930406.0024

10. R. Stumpe, J.I. Kim, W. Schrepp, H. Walter, "Speciation of Actinide Ions in Aqueous Solution by Laser Induced Photoacoustic Spectroscopy," Appl. Phys. B 34, 203-206 (1984). HQS.880517.2551

11. F.T. Ewart, M. Liezers, J.W. McMillan, P.M. Pollard, H.P. Thomason, "The Development of a Laser Induced Photoacoustic Facility for Actinide Speciation," report NSS/R103, Harwell Laboratory, Oxfordshire, U.K. (1988). HQX.880701.0010

12. J.E. Cross, D. Crossley, J.W. Edwards, P.M. Pollard, S. Turner, “Actinide Speciation. Further Development and Application of Laser Induced Photoacoustic Spectroscopy and Voltammetry," report NSS/R119, Harwell Laboratory, Oxfordshire, U.K. (1989). HQX.891211.0040

13. R.A. Torres, C.E. Palmer, P.A. Baisden, R.E. Russo, R.J. Silva, “A Comparison of Photoacoustic Spectroscopy, Conventional Absorption Spectroscopy, and Potentiometry as Probes of Lanthanide Speciation," report UCRL-101760, Lawrence Livermore National Laboratory, Livermore, California, U.S.A. (1989). NNA.930326.0100

14. M.M. Doxtader, V.A. Maroni, J.V. Beitz, M. Heaven, "Laser Photoacoustic Spectroscopy for Trace Level Detection of Actinides in Groundwater," Mat. Res. Soc. Symp. Proc. 84, 173-185 (1987). NNA.930420.0099 
15. D.L. Clark, S.A. Ekberg, D.E. Morris, P.D. Palmer, and C. D. Tait, "Actinide (IV) and Actinide (VI) Carbonate Speciation Studies By Photoacoustic Spectroscopy and Nuclear Magnetic Resonance Spectroscopies," report LA-12820-MS, Los Alamos National Laboratory, New Mexico (1994).

16. H. Nitsche, S.C. Lee, R.C. Gatti, "Determination of Plutonium Oxidation States at Trace Levels Pertinent to Nuclear Waste Disposal," J. Radioanal. Nucl. Chem. 124(1), 171-185 (1988). NNA.930326.0099

17. T.W. Newton, The Kinetics of the Oxidation-Reduction Reactions of Uranium, Neptunium, Plutonium, and Americium in Aqueous Solutions, National Technical Information Service, Springfield, Virginia, (1975). Readily Available.

18. D.B. Tucker, E.M. Standifer, H. Nitsche, and R.J. Silva, "Data Acquisition and Feedback Control System for Solubility Studies of Nuclear Waste Elements," Lanthanide and Actinide Research 2, 279-287 (1988). NNA.930326.0096

19. T.W. Newton, D.E. Hobart, P.D. Palmer, "The Preparation and Stability of Pure Oxidation States of Neptunium, Plutonium, and Americium," report LA-UR-86967, Los Alamos National Laboratory, Los Alamos, New Mexico (1986). NNA.930406.0025

20. H. Nitsche and N.M. Edelstein, "Solubilities and Speciation of Selected Transuranium Ions. A Comparison of a Non-Complexing Solution with a Groundwater from the Nevada Tuff Site," Radiochim Acta 39, 23 (1985). NNA.930326.0097

21. D. Cohen, "Electrochemical Studies of Plutonium Ions in Perchloric Acid Solution," J. Inorg. Nucl. Chem. 18, 207 (1961). NNA.930326.0098

22. G.A. Burney, R.M. Harbour, "Radiochemistry of Neptunium," NAS-NS 3060, Nuclear Science Series, National Academy of Sciences-National Research Council, 22-25 (1974). NNA.930326.0095

23. D. Cohen, "The Absorption Spectra of Plutonium Ions in Perchloric Acid Solution," J. Inorg. Nucl. Chem. 18, 211 (1961). NNA.930326.0094

24. P.G. Hagan, J.M. Cleveland, "The Absorption Spectra of Neptunium Ions in Perchloric Acid Solution,” J. Inorg. Nucl. Chem. 28, 2905 (1966). NNA.930326.0093

25. S.L. Phillips, C.A. Phillips, and J. Skeen, "Hydrolysis, Formation and Ionization Constants at $25^{\circ} \mathrm{C}$, and at High Temperature-High Ionic Strength," Report LBL14996, Lawrence Berkeley Laboratory, University of California, Berkeley, California (1985). NNA.930430.0016

26. The Polymer Corporation, Product Bulletin BR-10 8/84, Reading, PA (1984). NNA.930406.0029

27. M. Bernfopf and J.I. Kim, "Hydrolyse-Reaktionen und Karbonat Komplexierung von Dreiwertigem Americium im Natürlichen Aquatischen System," report RCM-02884, Technical University, Munich, FRG, (1984)

28. H. Nitsche, R.C. Gatti, and S.C. Lee, "Low-level Determination of Plutonium by Gamma and $L$-X-ray Spectroscopy," Proceedings of International Topical Conference on Methods and Applications of Radioanalytical Chemistry-III, April 21-27, Kona, Hawaii (in press, 1991). NNA.930326.0092

29. R.D. Lindberg and D.D. Runnells, "Ground Water Redox Reactions: An Analysis of Equilibrium State Applied to Eh Measurements and Geochemical Modeling," Science 225, No. 4665, 925-927 (1984). 
30. R.M. Garrels, Mineral Equilibria at Low Temperature and Pressure, Harper and Brothers, New York, N.Y.(1960). Readily Available.

31. D. Langmuir, "Eh-pH Determinations," in Procedures in Sedimentary Petrology, R.E. Carver, ed., 597-635, Wiley, New York, N.Y.(1971). Readily Available.

32. H. Nitsche, K. Roberts, T. Prussin, A. Müller, K. Becraft, D. Keeney, S.A. Carpenter, and R.C. Gatti, "Measured Solubilities and Speciations from Oversaturation Experiments of Neptunium, Plutonium, and Americium in UE-25p \#1 Well Water from the Yucca Mountain Region," report LBL-32897, Milestone Report 3329, Lawrence Berkeley Laboratory, California (1992). NNA.931015.0073

33. H. Nitsche, E.M. Standifer, and R.J. Silva, "Neptunium(V) Complexation with Carbonate," Lanthanide and Actinide Research 3, 203-211 (1990). NNA.930406.0027

34. Y.F. Volkov, G.L Visyashcheva, S.V. Tomilin, V.I. Spiryakov, I.I. Kapshukov, and A.G. Rykov, "Carbonate Compounds of Pentavalent Actinides with Alkali Metal Cations VII. Synthesis and Crystal Structure of Hydrate Compounds with the Composition $\mathrm{Na}_{0.6} \mathrm{NpO}_{2}\left(\mathrm{CO}_{3}\right)_{0.8} \bullet \mathrm{nH}_{2} 0$," Sov. Radiochem. (Eng. transl.) 21, 583-590 (1979). NNA.930420.0098

35. Y.F. Volkov, G.I. Visyashcheva, S.V. Tomilin, I.I. Kapshukov, and R.G. Rykov, "Study of Carbonate Compounds of Pentavalent Actinides with Alkali-Metal Cations. VIII. Synthesis and X-Ray Diffraction Investigation of Several Compounds of Neptunium(V) with Sodium and Rubidium," Sov. Radiochem. (Eng. transl.) 23, 191-195 (1981). NNA.930326.0091

36. Y.F. Volkov, G.I. Visyashcheva, and I.I. Kapshukov, "Study of Carbonate Compounds of Pentavalent Actinides with Alkali-Metal Cations. V. Production and Identification of Hydrate Forms of Sodium Monocarbonato-neptunylate ," Sov. Radiochem. (Eng. transl.) 19, 263-266 (1977). NNA.930326.0089

37. Y.F. Volkov, S.V. Tomilin, G.I. Visyashcheva, and I.I. Kapshukov, "Carbonate Compounds of Pentavalent Actinoids with Alkali-Metal Cations. VI. X-Ray Structure Analysis of $\mathrm{LiNpO}_{2} \mathrm{CO}_{3}$ and $\mathrm{NaNpO}_{2} \mathrm{CO}_{3}$," Sov. Radiochem. (Eng. transl.) 21, 579-583 (1979). NNA.930326.0090

38. M.P. Neu, D.C. Hoffman, K.E. Roberts, H. Nitsche, and R.J. Silva, "Comparison of Extractions and Laser Photoacoustic Spectroscopy for the Determination of Plutonium Species in Carbonate Solution," manuscript in preparation (1993).

39. G.L. Silver, "Suggestion for the Determination of Plutonium Valencies in Aqueous Solutions," Radiochem. Radioanal. Lett. 9, 5-6, 315-320 (1972). NNA.930326.0087

40. J. M. Clevelend, The Chemistry of Plutonium, Section 4.2(b), American Nuclear Society, La Grange Park, IL, (1979). Readily Available.

41. R.C.L. Mooney and W.H. Zachariasen, The Transuranium Elements Part II, G.T. Seaborg, J.J. Katz, and W.M. Manning, eds., 1442-1447, McGraw-Hill, New York, N.Y. (1949). Readily Available.

42. K.W. Bagnall and J.B. Laidler, "Neptunium and Plutonium Trioxide Hydrates," J. Chem. Soc., 2693-2696 (1964). NNA.930326.0084

43. F.H. Ellinger and W.H. Zachariasen, "The Crystal Structure of $\mathrm{KPuO}_{2} \mathrm{CO}_{3}, \mathrm{NH}_{4} \mathrm{PuO}_{2} \mathrm{CO}_{3}$ and $\mathrm{RbAmO}_{2} \mathrm{CO}_{3}$," J. Phys. Chem. 58, $405-408$ (1954). NNA.930326.0082

44. J. Navratil and Bramlet, "Preparation and Characterization of Plutonyl(VI) Carbonate," J. Inorg. Nucl. Chem. 35, 157-163 (1973). NNA.930326.0083 
45. R.J. Silva and H. Nitsche, "Thermodynamic Properties of Chemical Species of Waste Radionuclides," Report NUREG/CP-0052, U.S. Nuclear Regulatory Commission, Washington, D.C. (1983). HQS.880517.206

46. R.D. Shannon, "Revised Effective Ionic Radii and Systematic Studies of Interatomic Distances in Halogennides and Chalcogenides," Acta Cryst. A 32, 751-767 (1976). NNA.930326.0080

47. E.M. Standifer and H. Nitsche, "First Evidence for Hexagonal $\mathrm{AmOHCO}_{3}$," Lanthanide and Actinide Research 2, 383-384 (1988). NNA.880829.0064

48. H. Dexpert and P. Caro, "Determination de la Structure Cristalline de le Variete A des Hydroxycarbonates de Terres Rares $\mathrm{LnOHCO}_{3}(\mathrm{Ln}=\mathrm{Nd})$," Mat. Res. Bull, 9, 1577-1586 (1974). NNA.930406.0030 


\section{APPENDIX A}

RESULTS OF NEPTUNIUM SOLUBILITY EXPERIMENTS

IN UE-25p \#1 WATER 
Appendix IA. Results of Neptunium solubility experiments from oversaturation in UE-25p \#1 water at $60^{\circ} \mathrm{C}$ and $\mathrm{pH} 6.0$

\begin{tabular}{lcll}
\multicolumn{1}{c}{ Sample I.D. } & Days & $\mathrm{pH}$ & Concentration $(\mathrm{M})$ \\
\hline Initial amount added & 0 & - & $(5.6 \pm 0.2) \times 10^{-3}$ \\
1-1A6U6 & 1 & 6.04 & $(2.32 \pm 0.11) \times 10^{-3}$ \\
1-2A2U6 & 10 & 5.98 & $(2.62 \pm 0.11) \times 10^{-3}$ \\
1-3A2U6 & 16 & 6.07 & $(2.67 \pm 0.12) \times 10^{-3}$ \\
1-4A1U6 & 31 & 6.04 & $(2.60 \pm 0.11) \times 10^{-3}$ \\
1-5A1U6 & 43 & 6.02 & $(2.65 \pm 0.09) \times 10^{-3}$ \\
1-6A1U6 & 59 & 5.99 & $(2.59 \pm 0.10) \times 10^{-3}$ \\
1-7A2U6 & 87 & 6.02 & $(2.61 \pm 0.10) \times 10^{-3}$ \\
1-8A1U6 & 101 & 6.02 & $(2.27 \pm 0.09) \times 10^{-3}$ \\
1-9A1U6 & 111 & 5.97 & $(2.43 \pm 0.09) \times 10^{-3}$ \\
1-10A1U6 & 143 & 6.04 & $(2.22 \pm 0.07) \times 10^{-3}$ \\
1-11A1U6 & 170 & 6.01 & $(2.28 \pm 0.08) \times 10^{-3}$ \\
& & & \\
\hline
\end{tabular}

average 1-1A6U6 through 1-11A1U6

$(2.48 \pm 0.18) \times 10^{-3}$ 
Appendix IIA. Results of Neptunium solubility experiments from oversaturation in UE$25 p$ \#1 water at $60^{\circ} \mathrm{C}$ and $\mathrm{pH} 7.0$

\begin{tabular}{lcll}
\multicolumn{1}{c}{ Sample I.D. } & Days & $\mathrm{pH}$ & Concentration $(\mathrm{M})$ \\
\hline Initial amount added & 0 & - & $(1.5 \pm 0.1) \times 10^{-3}$ \\
2-1 A6U6 & 1 & 7.02 & $(6.66 \pm 0.22) \times 10^{-5}$ \\
2-2A2U6 & 10 & 6.96 & $(3.35 \pm 0.12) \times 10^{-5}$ \\
2-3A2U6 & 16 & 7.09 & $(2.98 \pm 0.11) \times 10^{-5}$ \\
2-4A1U6 & 31 & 7.10 & $(2.90 \pm 0.12) \times 10^{-5}$ \\
2-5A1U6 & 43 & 7.10 & $(3.09 \pm 0.11) \times 10^{-5}$ \\
2-6A1U6 & 59 & 6.88 & $(3.62 \pm 0.14) \times 10^{-5}$ \\
2-7A2U6 & 87 & 7.09 & $(3.54 \pm 0.16) \times 10^{-5}$ \\
2-8A1U6 & 101 & 7.03 & $(2.26 \pm 0.14) \times 10^{-5}$ \\
2-9A1U6 & 111 & 6.97 & $(5.07 \pm 0.22) \times 10^{-5}$ \\
2-10A1U6 & 143 & 7.07 & $(2.79 \pm 0.09) \times 10^{-5}$ \\
2-11A1U6 & 170 & 7.07 & $(5.14 \pm 0.28) \times 10^{-5}$ \\
2-12A1U6 & 183 & 7.06 & $(2.11 \pm 0.11) \times 10^{-5}$ \\
\hline
\end{tabular}


Appendix IIIA. Results of Neptunium solubility experiments from oversaturation in UE-25p \#1 water at $60^{\circ} \mathrm{C}$ and $\mathrm{pH} 8.5$

Sample I.D.

Initial amount added
3-1 A6U6
3-2A2U6
3-3A2U6
3-4A1U6
3-5A1U6
3-6A1U6
3-7A6U6
3-8A1U6
3-9A1U6
3-10A1U6
3-11A1U6

\section{Days}

0

1

10

16

31

43

59

87

101

111

143

155
$\mathrm{pH}$

$-$

8.45

8.34

8.31

8.32

8.54

8.40

8.50

8.50

8.37

8.45

8.50
Concentration (M)

$(1.5 \pm 0.1) \times 10^{-3}$

$(9.22 \pm 0.44) \times 10^{-6}$

$(8.43 \pm 0.31) \times 10^{-6}$

$(8.43 \pm 0.34) \times 10^{-6}$

$(9.17 \pm 0.39) \times 10^{-6}$

$(1.15 \pm 0.05) \times 10^{-5}$

$(1.23 \pm 0.06) \times 10^{-5}$

$(1.26 \pm 0.06) \times 10^{-5}$

$(1.55 \pm 0.09) \times 10^{-5}$

$(1.50 \pm 0.09) \times 10^{-5}$

$(2.35 \pm 0.13) \times 10^{-5}$

$(2.68 \pm 0.09) \times 10^{-5}$

assay 3-11 A $1 \mathrm{U} 6$

$(2.68 \pm 0.09) \times 10^{-5}$ 
Appendix IVA. Results of Neptunium solubility experiments from undersaturation in UE-25p\#1 water at $60^{\circ} \mathrm{C}$ and $\mathrm{pH} 6.0$

\begin{tabular}{|c|c|c|c|}
\hline Sample I.D. & Days & $\mathrm{pH}$ & Concentration (M) \\
\hline Initial solid added & 0 & 6.00 & - \\
\hline 1-12A1U6 & 0.05 & 6.35 & $(2.28 \pm 0.08) \times 10^{-3}$ \\
\hline $1-13 A 1 U 6$ & 1 & 6.03 & $(4.15 \pm 0.22) \times 10^{-4}$ \\
\hline 1-14A1U6 & 6 & 5.92 & $(6.18 \pm 0.29) \times 10^{-4}$ \\
\hline $1-15 \mathrm{~A} 1 \mathrm{U} 6$ & 28 & 6.00 & $(1.14 \pm 0.03) \times 10^{-3}$ \\
\hline 1-16A1U6 & 55 & 6.09 & $(1.59 \pm 0.06) \times 10^{-3}$ \\
\hline 1-17A1U6 & 85 & 5.97 & $(2.16 \pm 0.07) \times 10^{-3}$ \\
\hline $1-18 \mathrm{~A} 1 \mathrm{U} 6$ & 124 &.--- & $(2.42 \pm 0.08) \times 10^{-3}$ \\
\hline 1-19A1U6 & 168 & 5.64 & $(3.44 \pm 0.10) \times 10^{-3}$ \\
\hline 1-20A1U6 & 197 & 5.93 & $(2.40 \pm 0.10) \times 10^{-4}$ \\
\hline 1-21 A1U6 & 204 & 6.98 & $(3.18 \pm 0.20) \times 10^{-4}$ \\
\hline $1-22 \mathrm{~A} 1 \mathrm{U} 6$ & 210 & 5.96 & $(4.23 \pm 0.24) \times 10^{-4}$ \\
\hline $1-23 A 1 U 6^{*}$ & 1 & 6.12 & $(2.27 \pm 0.16) \times 10^{-4}$ \\
\hline $1-24 \mathrm{~A} 1 \mathrm{U} 6^{*}$ & 7 & 6.01 & $(2.49 \pm 0.13) \times 10^{-4}$ \\
\hline $1-25 \mathrm{~A} 1 \mathrm{U} 6^{*}$ & 70 & 5.92 & $(4.85 \pm 0.14) \times 10^{-4}$ \\
\hline $1-26 A 1 U 6^{*}$ & 175 & 5.98 & $(4.02 \pm 0.13) \times 10^{-4}$ \\
\hline $1-27$ A $^{1} \mathrm{U}^{*}$ & 197 & 6.02 & $(4.48 \pm 0.19) \times 10^{-4}$ \\
\hline $1-28 \mathrm{~A} 1 \mathrm{U} 6^{*}$ & 200 & 6.31 & $(2.81 \pm 0.08) \times 10^{-4}$ \\
\hline assay 1-19A1U6 & & & $(3.44 \pm 0.10) \times 10^{-3}$ \\
\hline
\end{tabular}


Appendix VA. Results of Neptunium solubility experiments from undersaturation in UE-25p\#1 water at $60^{\circ} \mathrm{C}$ and $\mathrm{pH} 7.0$

\begin{tabular}{llll}
\multicolumn{1}{c}{ Sample I.D. } & Days & $\mathrm{pH}$ & Concentration (M) \\
\hline Initial solid added & 0 & - & - \\
2-13A1U6 & 0.02 & 7.28 & $(1.08 \pm 0.07) \times 10^{-5}$ \\
2-14A1U6 & 1 & 7.12 & $(1.65 \pm 0.10) \times 10^{-5}$ \\
2-15A1U6 & 8 & 7.08 & $(2.21 \pm 0.10) \times 10^{-5}$ \\
2-16A1U6 & 15 & 7.05 & $(3.39 \pm 0.16) \times 10^{-5}$ \\
2-17A1U6 & 42 & 6.93 & $(6.39 \pm 0.34) \times 10^{-5}$ \\
2-18A1U6 & 72 & 7.15 & $(4.21 \pm 0.18) \times 10^{-5}$ \\
2-19A1U6 & 111 &.--- & $(9.32 \pm 0.32) \times 10^{-5}$ \\
2-20A1U6 & 154 & 7.08 & $(1.04 \pm 0.03) \times 10^{-4}$ \\
2-21A1U6 & 183 & 7.36 & $(9.71 \pm 0.38) \times 10^{-5}$ \\
2-22A1U6 & 188 & 7.00 & $(1.11 \pm 0.07) \times 10^{-4}$ \\
\hline
\end{tabular}

average $2-19$ A1U6 through $2-22 \mathrm{~A} 1 \mathrm{U} 6$

$(1.01 \pm 0.07) \times 10^{-4}$ 
Appendix VIA. Results of Neptunium solubility experiments from undersaturation in UE-25p\#1 water at $60^{\circ} \mathrm{C}$ and $\mathrm{pH} 8.5$

\begin{tabular}{lccc} 
Sample I.D. & Days & $\mathrm{pH}$ & Concentration (M) \\
\hline Initial solid added & 0 & 8.50 & - \\
3-12A1U6 & 0.16 & 8.35 & $(4.79 \pm 0.26) \times 10^{-6}$ \\
3-13A1U6 & 1 & 8.45 & $(5.03 \pm 0.21) \times 10^{-6}$ \\
3-14A1U6 & 6 & 8.49 & $(5.20 \pm 0.28) \times 10^{-6}$ \\
3-15A1U6 & 9 & 8.50 & $(5.60 \pm 0.24) \times 10^{-6}$ \\
3-16A1U6 & 15 & 8.46 & $(5.68 \pm 0.21) \times 10^{-5}$ \\
3-17A1U6 & 43 & 8.49 & $(1.05 \pm 0.06) \times 10^{-5}$ \\
3-18A1U6 & 70 & 8.48 & $(1.19 \pm 0.06) \times 10^{-5}$ \\
3-19A1U6 & 100 & 8.48 & $(1.52 \pm 0.09) \times 10^{-5}$ \\
3-20A1U6 & 139 &.--- & $(1.36 \pm 0.08) \times 10^{-5}$ \\
3-21A1U6 & 183 & 8.65 & $(2.80 \pm 0.23) \times 10^{-5}$ \\
3-22A1U6 & 212 & 8.39 & $(3.66 \pm 0.11) \times 10^{-5}$ \\
3-23A1U6 & 258 & 8.53 & $(6.03 \pm 0.48) \times 10^{-5}$ \\
3-25A1U6 & 336 & 8.50 & $(2.63 \pm 0.11) \times 10^{-5}$ \\
\hline
\end{tabular}




\section{APPENDIX B}

RESULTS OF PLUTONIUM SOLUBILITY EXPERIMENTS

IN UE-25p \#1 WATER 
Appendix IB. Results of Plutonium solubility experiments from oversaturation in UE25p \#1 water at $60^{\circ} \mathrm{C}$ and $\mathrm{pH} 6.0$

\begin{tabular}{cccc} 
Sample I.D. & Days & $\mathrm{pH}$ & Concentration (M) \\
\hline Initial amount added & 0 & - & $(2.2 \pm 0.2) \times 10^{-4}$ \\
4-1 A6U6 & 1 & 5.87 & $(6.65 \pm 0.76) \times 10^{-9}$ \\
4-2A1U6 & 6 & 5.85 & $(2.18 \pm 0.14) \times 10^{-7}$ \\
4-3A1U6 & 9 & 5.67 & $(6.64 \pm 0.42) \times 10^{-7}$ \\
4-4A1U6 & 21 & 6.04 & $(1.41 \pm 0.09) \times 10^{-6}$ \\
4-5A1U6 & 37 & 5.96 & $(1.90 \pm 0.12) \times 10^{-6}$ \\
4-6A2U6 & 65 & 5.90 & $(8.97 \pm 0.56) \times 10^{-7}$ \\
4-7A1U6 & 79 & 6.90 & $(9.04 \pm 0.57) \times 10^{-7}$ \\
4-8A1U6 & 121 & 6.04 & $(7.11 \pm 0.45) \times 10^{-7}$ \\
4-9A1U6 & 176 & 6.16 & $(2.59 \pm 0.22) \times 10^{-7}$ \\
4-10A1U6 & 236 & 6.08 & $(7.22 \pm 0.63) \times 10^{-8}$ \\
4-11A1U6 & 258 & 5.90 & $(9.42 \pm 0.84) \times 10^{-8}$ \\
4-12A1U6 & 286 & 5.93 & $(9.91 \pm 0.89) \times 10^{-8}$ \\
\hline
\end{tabular}

average 4-10A1U6 through 4-12A1U6

$(8.85 \pm 1.43) \times 10^{-8}$ 
Appendix IIB. Results of Plutonium solubility experiments from oversaturation in UE25p \#1 water at $60^{\circ} \mathrm{C}$ and $\mathrm{pH} 7.0$

\begin{tabular}{lcll}
\multicolumn{1}{c}{ Sample I.D. } & Days & $\mathrm{pH}$ & Concentration $(\mathrm{M})$ \\
\hline Initial amount added & 0 & - & $(2.2 \pm 0.2) \times 10^{-4}$ \\
5-1 A6U6 & 1 & 7.33 & $(5.13 \pm 0.37) \times 10^{-8}$ \\
5-2A1U6 & 6 & 7.29 & $(1.96 \pm 0.12) \times 10^{-7}$ \\
5-3A1U6 & 9 & 7.35 & $(2.62 \pm 0.14) \times 10^{-7}$ \\
5-4A1U6 & 21 & 7.29 & $(3.45 \pm 0.22) \times 10^{-7}$ \\
5-5A1U6 & 37 & 7.31 & $(4.39 \pm 0.28) \times 10^{-7}$ \\
5-6A2U6 & 65 & 7.41 & $(2.88 \pm 0.18) \times 10^{-7}$ \\
5-7A1U6 & 79 & 7.64 & $(2.43 \pm 0.15) \times 10^{-7}$ \\
5-8A1U6 & 121 & 7.01 & $(2.26 \pm 0.14) \times 10^{-7}$ \\
5-9A1U6 & 176 & 7.25 & $(9.32 \pm 0.80) \times 10^{-8}$ \\
5-10A1U6 & 236 & 7.36 & $(8.13 \pm 0.71) \times 10^{-8}$ \\
5-11A1U6 & 274 & 6.88 & $(1.07 \pm 0.10) \times 10^{-7}$ \\
5-12A1U6 & 287 & 7.09 & $(8.07 \pm 0.73) \times 10^{-8}$ \\
\hline
\end{tabular}


Appendix IIIB. Results of Plutonium solubility experiments from oversaturation in UE$25 \mathrm{p} \# 1$ water at $60^{\circ} \mathrm{C}$ and $\mathrm{pH} 8.5$

\begin{tabular}{lcll}
\multicolumn{1}{c}{ Sample I.D. } & Days & $\mathrm{pH}$ & Concentration $(\mathrm{M})$ \\
\hline Initial amount added & 0 & - & $(2.0 \pm 0.2) \times 10^{-4}$ \\
6-1 A6U6 & 1 & 7.90 & $(3.40 \pm 0.22) \times 10^{-7}$ \\
6-2A1U6 & 6 & 7.98 & $(3.89 \pm 0.24) \times 10^{-7}$ \\
6-3A1U6 & 9 & 8.23 & $(4.01 \pm 0.25) \times 10^{-7}$ \\
6-4A1U6 & 21 & 8.54 & $(4.21 \pm 0.26) \times 10^{-7}$ \\
6-5A1U6 & 37 & 8.04 & $(4.84 \pm 0.30) \times 10^{-7}$ \\
6-6A2U6 & 65 & 8.49 & $(5.45 \pm 0.34) \times 10^{-7}$ \\
6-7A1U6 & 79 & 8.42 & $(8.59 \pm 0.54) \times 10^{-7}$ \\
6-8A1U6 & 121 & 8.44 & $(2.57 \pm 0.16) \times 10^{-6}$ \\
6-9A1U6 & 176 & 8.58 & $(2.02 \pm 0.17) \times 10^{-6}$ \\
6-10A1U6 & 236 & 8.51 & $(1.42 \pm 0.12) \times 10^{-6}$ \\
6-11A1U6 & 279 & 8.50 & $(7.00 \pm 0.63) \times 10^{-7}$ \\
6-12A1U6 & 294 & 8.43 & $(7.15 \pm 0.64) \times 10^{-7}$ \\
\hline
\end{tabular}


Appendix IVB. Results of Plutonium solubility experiments from undersaturation in UE-25p\#1 water at $60^{\circ} \mathrm{C}$ and pH 6.0

\begin{tabular}{lclc} 
Sample I.D. & Days & $\mathrm{pH}$ & Concentration (M) \\
\hline Initial solid added & 0 & 6.00 & - \\
4-13A1U6 & 0 & 6.27 & $(2.91 \pm 0.27) \times 10^{-8}$ \\
4-14A1U6 & 1 & 6.38 & $(7.09 \pm 0.64) \times 10^{-8}$ \\
4-15A1U6 & 15 & 6.14 & $(1.53 \pm 0.13) \times 10^{-7}$ \\
4-16A1U6 & 30 & 6.24 & $(1.10 \pm 0.09) \times 10^{-7}$ \\
4-17A1U6 & 73 & 5.98 & $(1.10 \pm 0.09) \times 10^{-7}$ \\
4-18A1U6 & 149 & 6.03 & $(7.07 \pm 0.61) \times 10^{-8}$ \\
4-19A1U6 & 156 & 6.08 & $(5.74 \pm 0.50) \times 10^{-8}$ \\
\end{tabular}


Appendix VB. Results of Plutonium solubility experiments from undersaturation in UE$25 \mathrm{p \# 1}$ water at $60^{\circ} \mathrm{C}$ and $\mathrm{pH} 7.0$

\begin{tabular}{lccc}
\multicolumn{1}{c}{ Sample I.D. } & Days & $\mathrm{pH}$ & Concentration (M) \\
\hline Initial solid added & 0 & 7.00 & - \\
5-13A1U6 & 0 & 7.31 & $(4.06 \pm 0.40) \times 10^{-8}$ \\
5-14A1U6 & 1 & 7.40 & $(5.51 \pm 0.50) \times 10^{-8}$ \\
5-15A1U6 & 13 & 7.24 & $(9.22 \pm 0.81) \times 10^{-8}$ \\
5-16A1U6 & 28 & 7.20 & $(1.03 \pm 0.09) \times 10^{-7}$ \\
5-17A1U6 & 71 & 6.95 & $(1.04 \pm 0.09) \times 10^{-7}$ \\
5-18A1U6 & 147 & 7.40 & $(4.26 \pm 0.37) \times 10^{-8}$ \\
5-19A1U6 & 153 & 6.86 & $(3.71 \pm 0.33) \times 10^{-8}$ \\
& & & \\
\hline
\end{tabular}

average 5-13A1U6 through 5-19A1U6

$(6.78 \pm 3.06) \times 10^{-8}$ 
Appendix VIB. Results of Plutonium solubility experiments from undersaturation in UE-25p\#1 water at $60^{\circ} \mathrm{C}$ and $\mathrm{pH} 8.5$

\begin{tabular}{lccc} 
Sample I.D. & Days & $\mathrm{pH}$ & Concentration (M) \\
\hline Initial solid added & 0 & 8.50 & - \\
6-13A1U6 & 0 & 8.43 & $(2.50 \pm 0.26) \times 10^{-8}$ \\
6-14A1U6 & 1 & 8.37 & $(5.30 \pm 0.48) \times 10^{-8}$ \\
6-15A1U6 & 8 & 8.34 & $(6.24 \pm 0.55) \times 10^{-8}$ \\
6-16A1U6 & 22 & 8.47 & $(6.94 \pm 0.60) \times 10^{-8}$ \\
6-17A1U6 & 65 & 8.44 & $(9.28 \pm 0.80) \times 10^{-8}$ \\
6-18A1U6 & 141 & 8.73 & $(1.78 \pm 0.15) \times 10^{-7}$ \\
6-20A1U6 & 156 &.-- & $(1.00 \pm 0.08) \times 10^{-7}$ \\
6-22A1U6 & 218 & 8.54 & $(1.08 \pm 0.10) \times 10^{-7}$ \\
6-23A1U6 & 237 & 8.52 & $(6.96 \pm 0.62) \times 10^{-8}$ \\
\hline
\end{tabular}


APPENDIX C

RESULTS OF AMERICIUM/NEODYMIUM SOLUBILITY EXPERIMENTS IN UE25p \#1 WATER 
Appendix IC. Results of Americium/Neodymium solubility experiments from oversaturation in UE-25p \#1 water at $60^{\circ} \mathrm{C}$ and pH 6.0

Sample I.D.

Days

$\mathrm{pH}$

Concentration (M)

$\begin{array}{lrll}\text { Initial amount added } & 0 & - & (2.3 \pm 0.1) \times 10^{-4} \\ \text { 7-1A6U6 } & 1 & 6.05 & (3.18 \pm 0.19) \times 10^{-6} \\ \text { 7-2A1U6 } & 9 & 5.99 & (1.33 \pm 0.07) \times 10^{-7} \\ \text { 7-3A1U6 } & 16 & 5.89 & (1.30 \pm 0.07) \times 10^{-7} \\ \text { 7-4A1U6 } & 28 & 6.01 & (4.20 \pm 0.23) \times 10^{-8} \\ \text { 7-5A1U6 } & 44 & 6.00 & (5.94 \pm 0.33) \times 10^{-8} \\ \text { 7-6A6U6 } & 72 & 6.05 & (7.88 \pm 0.64) \times 10^{-9} \\ \text { 7-7A1U6 } & 125 & 6.06 & (2.37 \pm 0.36) \times 10^{-9} \\ \text { 7-8A1U6 } & 183 & 5.90 & (2.59 \pm 0.20) \times 10^{-9} \\ \text { 7-9A1U6 } & 244 & 6.57 & (3.18 \pm 0.40) \times 10^{-9}\end{array}$

average 7-7A1U6 through 7-9A1U6

$(2.71 \pm 0.42) \times 10^{-9}$ 
Appendix IIC. Results of Americium/Neodymium solubility experiments from oversaturation in UE-25p \#1 water at $60^{\circ} \mathrm{C}$ and pH 7.0

\begin{tabular}{lccc} 
Sample I.D. & Days & $\mathrm{pH}$ & Concentration $(\mathrm{M})$ \\
\hline Initial amount added & 0 & - & $(2.3 \pm 0.1) \times 10^{-4}$ \\
8-1 A6U6 & 1 & 7.07 & $(7.92 \pm 0.65) \times 10^{-7}$ \\
8-2A1U6 & 9 & 7.06 & $(1.62 \pm 0.09) \times 10^{-8}$ \\
8-3A1U6 & 16 & 7.00 & $(3.80 \pm 0.24) \times 10^{-9}$ \\
8-4A1U6 & 28 & 7.08 & $(2.49 \pm 0.15) \times 10^{-8}$ \\
8-5A1U6 & 44 & 7.02 & $(1.06 \pm 0.30) \times 10^{-9}$ \\
8-6A6U6 & 72 & 7.06 & $(7.46 \pm 1.95) \times 10^{-10}$ \\
8-7A1U6 & 125 & 7.11 & $(6.73 \pm 1.92) \times 10^{-10}$ \\
\hline
\end{tabular}

average 8-6A6U6 through 8-7A1U6

$(7.09 \pm 0.52) \times 10^{-10}$ 
Appendix IIIC. Results of Americium/Neodymium solubility experiments from oversaturation in UE-25p \#1 water at $60^{\circ} \mathrm{C}$ and $\mathrm{pH} 8.5$

\begin{tabular}{llll} 
Sample I.D. & Days & $\mathrm{pH}$ & Concentration (M) \\
\hline Initial amount added & 0 & - & $(2.3 \pm 0.1) \times 10^{-4}$ \\
9-1 A6U6 & 1 & 7.78 & $(2.96 \pm 0.36) \times 10^{-7}$ \\
9-2A1U6 & 9 & 8.38 & $(2.49 \pm 0.13) \times 10^{-7}$ \\
9-3A1U6 & 16 & 8.64 & $(6.66 \pm 0.42) \times 10^{-9}$ \\
9-4A1U6 & 28 & 8.39 & $(1.58 \pm 0.09) \times 10^{-8}$ \\
9-5A1U6 & 44 & 8.42 & $(6.89 \pm 0.59) \times 10^{-9}$ \\
9-6A6U6 & 72 & 8.51 & $(5.19 \pm 0.44) \times 10^{-9}$ \\
9-7A1U6 & 125 & 8.46 & $(1.30 \pm 0.09) \times 10^{-8}$ \\
9-8A1U6 & 183 & 8.53 & $(6.89 \pm 0.52) \times 10^{-9}$ \\
9-9A1U6 & 244 & 8.61 & $(3.41 \pm 0.40) \times 10^{-9}$ \\
9-10A1U6 & 274 & 8.56 & $(2.99 \pm 0.47) \times 10^{-9}$ \\
9-11A1U6 & 308 & 8.54 & $(9.60 \pm 0.71) \times 10^{-9}$ \\
\hline
\end{tabular}

average 9-3A1U6 through 9-11A1U6

$(7.83 \pm 4.28) \times 10^{-9}$ 
Appendix IVC. Results of Americium/Neodymium solubility experiments from undersaturation in UE-25p \#1 water at $60^{\circ} \mathrm{C}$ and $\mathrm{pH} 6.0$

\begin{tabular}{llll} 
Sample I.D. & Days & $\mathrm{pH}$ & Concentration (M) \\
\hline Initial solid added & 0 & 6.00 & - \\
7-13A1U6 & 0 & 6.09 & $(3.04 \pm 0.37) \times 10^{-9}$ \\
7-14A1U6 & 1 & 6.12 & $(2.63 \pm 0.26) \times 10^{-9}$ \\
7-15A1U6 & 20 & 5.89 & $(4.36 \pm 0.42) \times 10^{-9}$ \\
7-16A1U6 & 64 & 6.12 & $(1.93 \pm 0.02) \times 10^{-9}$ \\
7-17A1U6 & 71 & 6.15 & $(7.56 \pm 1.82) \times 10^{-10}$ \\
7-18A1U6 & 113 & 6.09 & $(4.71 \pm 1.48) \times 10^{-10}$ \\
7-19A1U6 & 184 & 5.97 & $(6.74 \pm 4.73) \times 10^{-11}$ \\
7-20A1U6 & 233 & 6.03 & $(2.91 \pm 0.84) \times 10^{-10}$ \\
& & & \\
\hline
\end{tabular}

average 7-16A1U6 through 7-20A1U6

$(7.03 \pm 7.31) \times 10^{-10}$ 
Appendix VC. Results of Americium/Neodymium solubility experiments from undersaturation in UE-25p \#1 water at $60^{\circ} \mathrm{C}$ and $\mathrm{pH} 7.0$

\begin{tabular}{lccc} 
Sample I.D. & Days & $\mathrm{pH}$ & Concentration $(\mathrm{M})$ \\
\hline Initial solid added & 0 & 7.00 & - \\
8-9A1U6 & 0 & 7.38 & $(2.10 \pm 0.58) \times 10^{-9}$ \\
8-10A1U6 & 1 & 7.32 & $(2.36 \pm 0.59) \times 10^{-9}$ \\
8-11A1U6 & 8 &.-- & $(9.49 \pm 1.21) \times 10^{-10}$ \\
8-12A1U6 & 28 & 7.19 & $(4.07 \pm 0.90) \times 10^{-10}$ \\
8-13A1U6 & 63 & 6.79 & $(3.26 \pm 0.32) \times 10^{-9}$ \\
8-14A1U6 & 114 & 7.18 & $(7.20 \pm 1.59) \times 10^{-10}$ \\
8-17A1U6 & 227 & 7.14 & $(4.43 \pm 1.06) \times 10^{-10}$ \\
8-18A1U6 & 276 & 7.04 & $(2.37 \pm 0.68) \times 10^{-10}$ \\
8-19A1U6 & 289 & 6.93 & $(4.19 \pm 1.28) \times 10^{-10}$ \\
& & & \\
\hline
\end{tabular}

average 8-14A1U6 through 8-19A1U6

$(4.55 \pm 1.99) \times 10^{-10}$ 
Appendix VIC. Results of Americium/Neodymium solubility experiments from undersaturation in UE-25p \#1 water at $60^{\circ} \mathrm{C}$ and $\mathrm{pH} 8.5$

Sample I.D.

Days

$\mathrm{pH}$

Concentration (M)

Initial solid added

0

8.50

9-13A1U6

0

8.43

$(5.81 \pm 0.38) \times 10^{-9}$

9-15A1U6

8

8.47

$(2.24 \pm 0.23) \times 10^{-9}$

9-16A1U6

50

8.42

$(2.09 \pm 0.33) \times 10^{-9}$

9-17A1U6

131

8.54

$(1.03 \pm 0.54) \times 10^{-10}$

9-18A1U6

180

8.65

$(8.23 \pm 7.47) \times 10^{-11}$

9-19A1U6

188

8.51

$(6.63 \pm 6.38) \times 10^{-11}$

average 9-17A1U6 through 9-19A1U6

$(8.39 \pm 1.84) \times 10^{-11}$ 
The data used to write this report are recorded in the following YMP Laboratory Record Books:

TWS-LBL-02-90-04, pp. 231 - 299

TWS-LBL-10-91-04, pp. 1 - 211

TWS-LBL-02-91-01, pp. 39-70

TWS-LBL-01-92-02, pp. 1 - 209

TWS-LBL-01-93-02, pp. 1- 77 (open)

TWS-LBL-01-93-03, pp. 1- 37 (open)

TWS-LBL-01-93-04, pp. 1 - 79 (open)

End Date

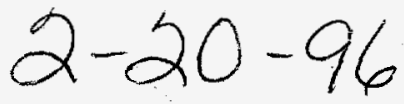

95 